\title{
O Fomento Florestal da CESP/Porto Primavera com Propriedades da Região de Assis-SP
}

\author{
ANDRÉ ROCHA FERRETTI
}

Engenheiro Florestal

Orientador: Prof. Dr. PAULO YOSHIO KAGEYAMA

Dissertação apresentada à Escola Superior de Agricultura "Luiz de Queiroz", Universidade de São Paulo, para a obtenção do título de Mestre em Ciências. Área de concentração: Ciências Florestais

\section{PIRACICABA}

Estado de São Paulo - BRASIL

Fevereiro - 2000 
Dados Internacionais de Catalogação na Publicação (CIP) DIVISÃO DE BIBLIOTECA E DOCUMENTAÇÃO - Campus "Luiz de Queiroz"/USP

Ferretti, André Rocha

O fomento florestal da CESP/Porto Primavera com propriedades da região de AssisSP / André Rocha Ferretti. - - Piracicaba, 2000.

$156 \mathrm{p}$.

Dissertação (mestrado) - Escola Superior de Agricultura Luiz de Queiroz, 2000. Bibliografia.

1. Ecologia florestal 2. Economia florestal 3. Incentivo florestal 4. Politica florestal 5. Produtor rural 6. Propriedade rural 7. Reflorestamento 8. Silvicultura sustentável 9. Viveiro florestal I. Título

$\operatorname{CDD} 634.92$ 


\section{DEDICATÓRIA}

Dedico este trabalho ao meu pai, Sergio Figueiredo Ferretti, e à minha mãe, Mundicarmo Maria Rocha Ferretti, os dois melhores exemplos de pesquisadores que já conheci, e que sempre estiveram a me dar incentivo e apoio. Foram eles que desde cedo despertaram meu interesse por árvores e plantas ornamentais, plantando várias frutíferas no quintal da nossa casa, logo após o meu nascimento, e que foram peças marcantes em toda a minha infầncia, entre elas: a goiabeira, o abacateiro, o abricó, o cajá-manga, e a amendoeira, a jussara, o coco-da-bahia, o jambo-vermelho, a chuva-de-ouro, o pau-d'arco e a acácia.

“... Talvez agora percebas que as teorias, a despeito da beleza que irradiam, podem quando em muito prever acontecimentos, mas nunca descrever a floresta. Não importa que a isso te dediques por mil anos, pois depois de mil vezes mil anos, outra teoria mais poderosa e completamente diferente surgirá... A floresta transcende a qualquer descrição, pois não há linguagem finita que possa descrever o todo, e o todo é a floresta, e a floresta é o todo. Nunca entenderemos a floresta em sua essência dessa forma, pois para tanto precisamos penetrar em seu espirito, e penetrar em seu espirito é tocar o que é imutóvel."(George Matsas. O Espírito da Floresta. P. Jacques • M. Ohno / Editores. São Paulo, SP, 1993: 34-35) 


\section{AGRADECIMENTOS}

Agradeço ao Prof. Paulo Kageyama, meu orientador desde a graduação, e ao Prof. Oriowaldo Queda, co-orientador, que foram os grandes inspiradores desse trabalho. A vocês o meu muito obrigado pela amizade, incentivo, paciência e atenção dispensada.

Muito obrigado ao Japi, Marco Antônio Sampaio Malagodi, companheiro e amigo, sempre disposto a discutir as questões referentes à extensão rural e florestal, educação, legislação ambiental/florestal, e floresta tropical. Valeu Japi, obrigado pelas partidas de sinuca e de futebol, pelas viagens, pelos saraus, pelas serenatas que fizemos, pelas músicas que você me ensinou a tocar ao violão, e tudo mais.

Grande Gorpo, Luiz Antonio Ferraro Júnior, agradeço pela nossa grande amizade, pelos papos cabeça, pelos jogos de futebol que participamos e assistimos, pelas viagens, pelos vinhos que tomamos, pelos planos que fizemos..., mas principalmente pela familia que nos tornamos.

Obrigado aos amigos Marasmo (Tasso), grande companheiro de serenatas e saraus; Robson, companheiro nas bebedeiras, churrascos, e assistência técnica em informática; BB (Valéria), pelas conversas, amizade e paciência em suportar nossas bebedeiras; Frú (Fabiana), Hering (Marisol), Laís (Varinha), e todas as meninas da república "Gaiola das Lokas", pela amizade, pela hospitalidade, pela comida (bolos, almoços, churrascos...), por terem ouvido nossas serentas, pelas noites de violão e música, e pela beleza.

Meu muito obrigado ao Maciel e Teresa, que me encorajaram a mudar de tema de pesquisa no meio do caminho para buscar aquilo que realmente me dava motivação. 
Obrigado também aos meus pais, Sergio e Mundicarmo Ferretti, que estiveram sempre a postos para ajudar em todos os aspectos, desde financeiros até os técnicos propriamente ditos.

Meu muito obrigado a todos os que de alguma forma participaram do grupo "Florestas Sociais", professores, pós-graduandos e estagiários, e em especial ao Prof. Marcos Sorrentino, que sempre nos incentivou a refletir sobre a política florestal e o movimento ambientalista.

Valeu Golf Boys, Ariel, Kibe e Cláudio, pela amizade, festas, churrascos, futebol, piadas, gírias, e pela alegria e descontração que trouxeram à Piracicaba e ao curso. Um muito obrigado todo especial ao Ariel, companheiro de futebol, churrasco, Rua do Porto, cerveja, e pela força nos momentos finais da dissertação, agilizando toda a parte burocrática junto à seção de alunos, biblioteca...

Obrigado ao João Del Giudice Neto, pela amizade e pela ajuda nas disciplinas de genética, e a todos os colegas de curso do Mestrado em Ciências Florestais e Tecnologia da Madeira, bem como a todos os amigos não ligados à ESALQ.

Muito obrigado aos funcionários do Departamento de Ciências Florestais, a quem agradeço nas pessoas do Amarildo e do Rogério, que sempre nos ajudaram da melhor maneira possível.

Muito obrigado ao Marcelo Crestana, chefe, mestre e amigo, e a todos os colegas da CATI, pela confiança, amizade, e incentivo. Obrigado Washington Agueda, Gerson Groppo, Carraro, Neves, Escolástica, João Adonai, Gilmar e ao pessoal da C. A. de Palmital, Míriam e a todos do DEXTRU e Programa "Margem Verde".

Obrigado aos professores Flávio (Dil) e Leonardo, pelas sugestões no exame de qualificação, e pela amizade.

Agradeço a CESP, pela autorização para a realização do trabalho e fornecimento de dados, e em especial a toda a equipe do viveiro da CESP de Porto Primavera (João Henrique Pinheiro Dias, Washington Luiz de Azevedo Geres, Francisco Dias da Silva, Celso Machado, Cláudio Santos Viana, Marcos Roberto Macedo, Nilson Neuhaus e César Augusto Scheide), pela cooperação, apoio e ótima recepção. 


\section{SUMÁRIO}

Página

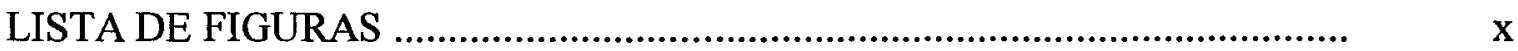

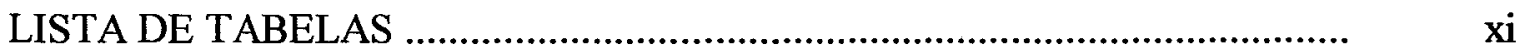

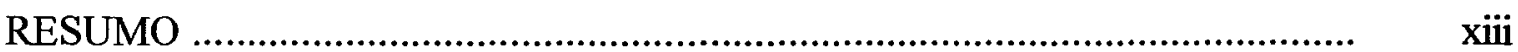

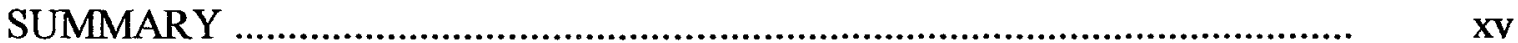

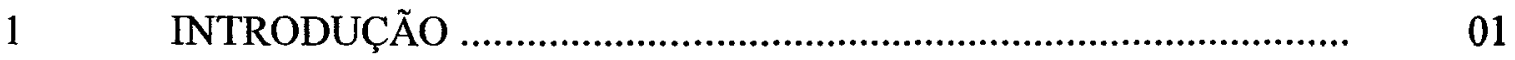

$2 \quad$ REVISÃO DE LITERATURA ............................................... 04

2.1 Extensão e Fomento Florestal: base conceitual ................................. 04

2.2 Florestas Sociais e o Elemento Arbóreo na Propriedade Rural ............ 10

2.3 A Situação do Fomento Florestal no Brasil e no Estado de São Paulo 14

2.4 O Fomento Florestal da CESP ................................................... 18

2.5 O modelo de plantio misto de espécies nativas da CESP (Modelo CESP) (........................................................................... 24

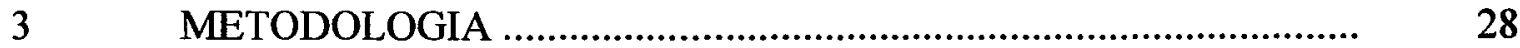

A proposta inicial de trabalho ........................................................ 29

O trabalho realizado ............................................................... 31

3.3 Coleta de dados: a opção por formulários de pesquisa ....................... 34

$4 \quad$ RESULTADOS E DISCUSSÃO ............................................ 41

4.1 Definição do Universo de Estudo: levantamento do número total de contratos de fomento estabelecidos e definição da amostra a ser pesquisada ................................................................................... 41

4.2 Estrutura Fundiária da Região Estudada ........................................ 47

4.3 O fomento florestal da CESP no município de Palmital ..................... 50 
Página

4.4 Caracterização das propriedades que responderam os formulários de pesquisa enviados pelo correio

4.5 Análise das respostas aos formulários de pesquisa 65

4.5.1 A divulgação do Programa 66

4.5.2 Motivos que têm levado os produtores a plantar árvores nativas

4.5.3 Situação das margens de rios, córregos e lagos, e das nascentes da propriedade

4.5.4 Existência de fragmentos de mata na propriedade 72

4.5.5 Alternativas florestais de interesse dos produtores 73

4.5.6 Mão-de-obra utilizada para plantio e manutenção .............................. 74

4.5.7 Implantação de reflorestamentos sem a parceria da CESP ................... 76

4.5.8 Participação na escolha das espécies plantadas ................................ 77

4.5.9 Compreensão pelo produtor do modelo de plantio da CESP .............. 80

4.5.10 Razões que levaram alguns produtores a desistir do contrato de fomento florestal com a CESP

4.5.11 Avaliação do Programa pelo produtor ............................................. 82

ANEXO A: Carta de apresentação e intenções ao Diretor de Meio Ambiente da CESP

ANEXO B: Carta de autorização da CESP para o desenvolvimento do trabalho.

ANEXO C: Formulário de pesquisa para o PÚBLICO 1

ANEXO D: Formulário de pesquisa para o PÚBLICO 2 .

ANEXO E: Formulário de pesquisa para o PÚBLICO 3 .

ANEXO F: Carta ao proprietário rural fomentado pela CESP

ANEXO G: Lista de municípios com contratos de fomento florestal com o viveiro da CESP de Porto Primavera até dezembro de 1997

ANEXO H: Resumo das respostas fornecidas pelos proprietários com contratos de fomento florestal vigentes 
Página

ANEXO I: Resumo das respostas fornecidas pelos proprietários com contratos de fomento florestal vencidos

ANEXO J: Resumo das respostas fornecidas pelos proprietários que desistiram do contrato de fomento florestal com a CESP

APÊNDICE 1: Folder: Fomento Florestal

APÊNDICE 2: Formulário de avaliação rápida a campo dos plantios fomentados

APÊNDICE 3: Questionário de entrevista aos proprietários fomentados

APÊNDICE 4: Questionário de entrevista aos funcionários da CESP envolvidos no Programa de fomento florestal da empresa

APÊNDICE 5: Ficha de cadastro da propriedade fomentada

APÊNDICE 6: Modelo de Contrato de fomento florestal

APÊNDICE 7: Modelo de ficha de dados cadastrais do proprietário 


\section{LISTA DE FIGURAS}

Página

1 - Gráfico da estrutura fundiária do Estado de São Paulo e da região de Assis ..

2 - Gráfico da estrutura fundiária do EDR de Assis e das propriedades amostradas 


\section{LISTA DE TABELAS}

Página

$1 \quad \mathrm{~N} .^{\circ}$ de contratos de fomento florestal organizados por Escritório de Desenvolvimento Rural da CATI/SAA-SP

2 N. ${ }^{\circ}$ Contratos de fomento organizados por município do EDR de Assis, e classificados em contratos vigentes, vencidos e desistentes ..

3 N. ${ }^{\circ}$ Cartas e formulários de pesquisa enviados por município do EDR de Assis, agrupados em contratos vigentes, vencidos e desistentes

4 Estratificação das Propriedades Agropecuárias do Estado de São Paulo em classes de tamanho

5 Estratificação das Propriedades Agropecuárias do Escritório de Desenvolvimento Rural da CATI de Assis, em classes de tamanho ...

6 N. ${ }^{\circ}$ Solicitações de produtores rurais para participar do fomento florestal da CESP, listadas por ano, e situação dos contratos de fomento em dezembro de 1997 
Página

7 Evolução da área plantada, em hectares, pelo Programa de Recomposição de Matas Nativas da CESP

8 Número de mudas e de espécies fornecidas aos fomentados da CESP em Palmital no ano de 1996

9 Número de mudas e de espécies fornecidas aos fomentados da CESP em Palmital no ano de 1997

$10 \mathrm{~N} .^{\circ}$ de formulários de pesquisa enviados e respondidos, e cartas devolvidas pelo correio, listadas por município do EDR de Assis .....

11 Estratificação das Unidades de Produção Agropecuárias do EDR de Assis e das Propriedades Amostradas em classes de tamanho 


\title{
O Fomento Florestal da CESP/Porto Primavera com Propriedades da Região de Assis-SP
}

\author{
Autor: ANDRÉ ROCHA FERRETTI \\ Orientador: Prof. PAULO YOSHIO KAGEYAMA
}

\section{RESUMO}

Com o objetivo de analisar o Programa de Fomento Florestal do viveiro de produção de mudas da CESP de Porto Primavera; identificar o que levou os produtores fomentados pelo viveiro a participar, ou desistir, do Programa de Fomento Florestal da Companhia; saber como este público avalia o Programa; e registrar possíveis sugestões e reivindicações dos produtores, foram enviados formulários de pesquisa com questões de múltipla escolha para os signatários de 280 contratos de fomento florestal estabelecidos com a empresa, distribuídos nos seguintes municípios da região de Assis, no Estado de São Paulo: Cândido Mota, Palmital, Florínea, Assis, Maracaí, Tarumã, Campos Novos Paulista, Paraguaçu Paulista, Pedrinhas Paulista, Cruzália, Ibirarema e Platina.

Obteve-se resposta de $20,00 \%$ do total, sendo que $10,71 \%$ das correspondências foram devolvidas. A partir dos resultados obtidos, não se confirmou a hipótese de que grande parte dos produtores aderiram ao Programa principalmente pelo fato de poder receber mudas e assistência técnica gratuitas, o que indica tratar-se de um incentivo necessário, mas não suficiente. Verifica-se que a questão legal, aliada ao temor da ação das diversas instituições ligadas ao setor de meio ambiente, foi o motivo principal que 
levou os produtores rurais, que responderam aos formulários, a participar do fomento florestal da CESP. Por outro lado, a conservação dos recursos hídricos e do solo também têm motivado muitos produtores para o plantio de espécies florestais nativas, indicando que os produtores estão preocupados diretamente com a conservação dos recursos naturais, mais diretamente ligados à produção agropecuária, disponíveis em suas áreas.

O principal enfoque do programa de fomento florestal analisado está na produção de mudas, aproveitando toda a estrutura fisica do viveiro, que tem capacidade para produzir muito mais mudas de boa qualidade genética e fisiológica, do que a Companhia tem capacidade de plantar. A maior dificuldade está na efetivação do plantio, tanto em áreas da Companhia quanto em propriedades particulares. Neste sentido, o Programa deveria se ater mais às ações de divulgação, sensibilização do produtor rural, e busca de alternativas que possibilitasse a presença do elemento arbóreo na propriedade agrícola, tanto como componente econômico quanto ambiental.

É importante destacar que, mais do que a repressão, as informações obtidas indicam que o incentivo à adoção do elemento arbóreo na propriedade rural, desenvolvendo-se alternativas florestais que respondam às demandas do produtor, são o melhor caminho para o crescimento do Programa de Fomento Florestal na região. O modelo de reflorestamento misto com espécies nativas desenvolvido pela CESP, mais do que um modelo de implantação de um trecho de mata ciliar dentro de uma propriedade, é uma oportunidade para que se veja a árvore e a floresta com outros olhos. 


\title{
The Public Agency Providing of the São Paulo State Energy Company (CESP) - Porto Primavera Unit - at Properties in the Assis Region, in São Paulo State, Brazil
}

\author{
Author: ANDRÉ ROCHA FERRETTI \\ Adviser: Prof. PAULO YOSHIO KAGEYAMA
}

\section{SUMMARY}

Research forms with multiple choice questions were sent to the signers of the 280 contracts of Public Agency Providing established with the São Paulo State Energy Company (CESP), Porto Primavera Unit. This was done with the objective to analyze the Company's Program of Public Agency Providing in the nursery for seedling production, to identify what made the producers that were fomented by the nursery participate in - or desist from participating in - the Companies' Program, to get to know how the concerned public does evaluate the Program, and to make register of possible suggestions and demands of the producers. The referred contracts were distributed in the following municipalities: Cândido Mota, Palmital, Florínea, Assis, Maracaí, Tarumã, Campos Novos Paulista, Paraguaçu Paulista, Pedrinhas Paulista, Cruzália, Ibirarema e Platina. All these municipalities are situated in the Assis region of São Paulo State.

Of the total number of letters sent, $20,00 \%$ were answered and another $10,71 \%$ were returned unanswered. The obtained results did not confirm the hypothesis that a large part of the producers would adhere to the Program particularly for the reason that they thus could receive seedlings and technical assistance free of charge. This indicates 
that the incentive is insufficient, though necessary. It was also verified that - amongst the rural producers that answered the form - the main motive which made them participate in the Public Agency Providing of the São Paulo State Energy Company, was the question of legality, added to fear for actions that could possibly be taken by institutions linked to the environmental sector. On the other hand, also soil conservation and of the water resources did motivate many producers to plant native forest species. This indicates that the producers are really concerned about the conservation of those natural resources that are available on their areas and which are more directly related to income through agriculture and cattle breeding.

The analyzed program of public agency providing did focus mainly upon the production of seedlings, since a better use had to be made of the entire nurseries' physical structure, which has the capacity to produce much more seedlings of good genetic and physiological quality than the Company is capable to plant. The largest difficulty is in the accomplishment of this planting, both in areas of the Company as well as in private properties. In this regard, the Program should be directed and restricted more to activities of communication and to the creation of awareness of the rural producer. It should also be directed to a search for alternatives that make the presence of the arboreal element on the farmer's property possible, with regard to both the economic as well as to the environmental component.

The obtained information clearly shows that encouragement towards the adoption of the arboreal element on the rural property - by developing forestry alternatives that form a response to the producer's demands - is the best way towards growth of the region's Program for Public Agency Providing. It is a much better way than repression, and this must be emphasized! More than a model for the implantation of a stretch of gallery forest within a property, the reforestment mixed with native species as developed by the São Paulo State Energy Company, must be considered an opportunity towards making the tree and forest being seen through a different light. 


\section{INTRODUÇÃO}

A CESP, Companhia Energética de São Paulo, vem fazendo pesquisa básica e desenvolvendo tecnologia de restauração florestal em áreas de domínio da floresta tropical, com vasta aplicação desses conhecimentos em plantios realizados há mais de 20 anos nas áreas de influência dos reservatórios de suas usinas hidrelétricas.

Diversas outras instituições públicas e não governamentais vêm atuando na restauração florestal, mas nenhuma se compara à CESP em área plantada e em pesquisas desenvolvidas. O conhecimento técnico florestal acumulado até o momento para se obter sucesso na produção de mudas e plantio de espécies nativas ainda pode avançar muito, mas já é suficiente para garantir bons resultados.

O fomento florestal no Estado de São Paulo tem sido orientado para a produção de matéria-prima para a indústria de celulose e papel, e madeira para energia, graças principalmente às empresas privadas que atuam no setor, e às associações de reposição florestal, que vêm incentivando o plantio quase que exclusivo de florestas homogêneas de espécies exóticas. As espécies nativas representam uma parcela muito pequena do fomento florestal no Brasil e em São Paulo, sendo a CESP um representante de destaque deste segmento. A Companhia desenvolve programas de fomento florestal através de cinco viveiros de produção de mudas no Estado de São Paulo (Ilha Solteira, Jupiá, Paraibuna, Porto Primavera, e Promissão), levando sua tecnologia ao alcance do produtor rural. 
Analisando diversos programas de fomento florestal, como os desenvolvidos pela CESP, e principalmente pela Fundação Florestal, onde o autor teve a oportunidade de participar de um programa de estágio de graduação durante os anos de 1993 e 1994, constatou-se que para se restaurar as áreas de matas ciliares não era necessário apenas instalar viveiros e produzir mudas de boa qualidade. Era preciso conhecer aquele que iria plantar e cuidar destas mudas. Ficava cada vez mais evidente a necessidade de se incluir o ser humano, e suas relações com a árvore e a floresta, nos programas de fomento florestal.

O componente ambiental jamais poderá estar separado do social e do econômico, ou seja, nunca se poderá ver as margens dos rios e entorno de lagos e nascentes protegidos por florestas, se a cultura das pessoas que vivem nestas áreas e suas necessidades não forem levadas em conta. É preciso entender a relação do ser humano com o elemento arbóreo. É preciso recuperar o conhecimento florestal dos agricultores e proprietários de terras do Estado e buscar identificar o que os levou a retirar e eliminar as árvores e as florestas de suas terras, para depois se tentar reverter a situação trazendo o elemento arbóreo novamente para dentro da propriedade rural e da cultura dos produtores rurais.

O objetivo deste trabalho foi o de analisar o Programa de Fomento Florestal do viveiro de produção de mudas da CESP de Porto Primavera; identificar o que levou os produtores fomentados pelo viveiro a participar, ou desistir, do Programa de Fomento Florestal da Companhia; saber como este público avalia o Programa; e registrar possíveis sugestões e reivindicações dos produtores. Deste modo, as informações obtidas poderão ser utilizadas posteriormente para aprimorar o Programa de Fomento Florestal da CESP, e contribuir para outros programas que incentivem a presença da árvore e da floresta nas propriedades rurais. 
Parte-se das hipóteses de que, a principal motivação, para que os produtores rurais participem do Programa de fomento Florestal do viveiro, está na oportunidade de receber mudas e assistência técnica gratuitas; e de que os motivos que levam os produtores rurais a adotar o elemento arbóreo em suas propriedades são diferentes em função do tamanho da área e da participação das atividades produtivas ali praticadas no sustento da familia.

Quando da realização desta pesquisa, a CESP, que ainda era uma grande empresa estatal, mantinha um corpo técnico do mais alto nível em suas diversas unidades, e destacava-se nacional e internacionalmente pela quantidade e qualidade de pesquisas no setor florestal. Atualmente a Companhia está em pleno processo de privatização, sendo que boa parte dos técnicos que foram responsáveis por uma parcela considerável da evolução tecnológica na produção de mudas, plantio e estabelecimento de florestas foi desligada recentemente da Companhia, e o trabalho de mais de 20 anos corre o risco de ser interrompido por falta de visão de seus dirigentes.

A questão da descontinuidade é um problema que afeta todo o setor público, e no setor florestal não tem sido diferente. Um exemplo recente foi o Plano de Desenvolvimento Florestal Sustentado (PDFS), elaborado pela Fundação Florestal, órgão da Secretaria do Meio Ambiente do estado de São Paulo, no final do mandato do governo Fleury (1990-1994). O PDFS alertava para o fato de que originalmente mais de 80\% do Estado de São Paulo era recoberto por florestas, e que no início dos anos 90, esta cobertura representava menos de $10 \%$ da área. O Plano, que através do incentivo ao plantio de florestas com espécies nativas e exóticas, pretendia que em 20 anos a cobertura florestal do Estado chegasse a 25\% da área. 


\section{REVISÃO DE LITERATURA}

\subsection{Extensão e Fomento Florestal: base conceitual}

Em seu livro intitulado Extensão ou comunicação?, Freire (1983) alerta o leitor para o equívoco que o conceito de extensão pode conduzir, que segundo Ele seria o de estender um conhecimento técnico até os camponeses, em lugar de (pela comunicação eficiente) fazer do fato concreto ao qual se refira o conhecimento (expresso por signos lingüísticos) objeto de compreensão mútua dos camponeses e dos agrônomos.

"Extensão rural, segundo Swanson \& Claar, compõe-se de duas dimensões: uma comunicacional e outra educacional, sendo um processo dinâmico que consiste em levar ao produtor rural informações úteis e relevantes (dimensão comunicacional) e ajudá-lo a adquirir conhecimentos, habilidades e atitudes para utilizar com eficiência essas informações (dimensão educacional). $\mathrm{O}$ objetivo final desse processo é o de tornar o agricultor capaz de melhorar o seu nível de vida, pela utilização racional e efetiva dos conhecimentos, habilidades e informações adquiridas. Neste sentido, a Extensão rural se confunde com a educação não-formal e suas metodologias de trabalho são, de fato, empregadas em programas não especificamente agrícolas, tais 
como higiene, desenvolvimento comunitário ou planejamento familiar. A extensão rural é, portanto, um termo amplo, abrangendo as mais variadas atividades rurais, envolvendo diferentes tipos de organizações (públicas ou privadas) para atingir diversos públicos (homens, mulheres, jovens) com diferentes mensagens sociais" (Almeida, 1989).

De acordo com Mazuchowski (1991), geralmente, considera-se o produtor rural como sujeito e não objeto da ação, transferindo-se sua preocupação principal do solo, da planta e/ou do animal para o homem; em outras palavras, considera-se que é o bom produtor e não o bom ambiente que faz uma boa atividade silvoagropecuária. Em decorrência, segundo o Autor, destacam-se os seguintes conceitos de educação aplicados ao meio rural:

- Processo de desenvolvimento da capacidade física, intelectual e moral, do ser humano em geral, visando a sua melhor integração individual e social.

- Processo contínuo que possibilita condições para a tomada de consciência; parte do próprio agricultor, possibilitando o desenvolvimento de suas potencialidades, permitindo modificações no seu modo de relacionar-se consigo mesmo, com os outros e com o meio em que vive.

De acordo com Souza (1988), não sendo neutra, a tecnologia traz, em si, uma explicação social para o seu desenvolvimento, além de trazer, com sua adoção posterior pelo setor produtivo, conseqüências sociais variadas. É, principalmente, esta característica de não neutralidade implícita na tecnologia agropecuária, segundo o Autor, que torna imprescindível o relacionamento e o diálogo entre seus produtores (os pesquisadores), os seus divulgadores (os extensionistas) e os seus adotantes (os produtores agropecuários). Esse relacionamento torna-se ainda mais crucial quando sabese que produtores e extensionistas também produzem tecnologias; que pesquisadores e produtores também as divulgam e que, eventualmente, também pesquisadores e extensionistas adotam-nas. 
Como destaca Souza (1988), o primeiro grande passo da investigação agropecuária é a formulação clara do problema de pesquisa, de forma que possa ser trabalhado. Para o Autor, a identificação desse problema é resultado não só dos conhecimentos teóricos e metodológicos do pesquisador, como também do seu conhecimento e vivência da realidade que ele deseja explicar e transformar. Neste primeiro grande passo da investigação agropecuária, Souza (1988) destaca que a colaboração e participação dos extensionistas e produtores é inestimável, pois eles são parte integrante daquela realidade estudada pelo pesquisador. Nesta mesma linha de raciocínio, Freire (1983) também destaca a importância de se conhecer a realidade que se deseja entender e transformar, visto que para ele, o homem, que não pode ser compreendido fora de suas relações com o mundo - nestas relações com o mundo, através de sua ação sobre ele, o homem se encontra marcado pelos resultados de sua própria ação - , é um ser da ação e da reflexão, como também um ser do trabalho e da transformação do mundo.

Posteriormente, no desenvolvimento da pesquisa, o relacionamento pesquisa/extensão e pesquisa/extensão/produtor também pode acontecer de inúmeras maneiras, tais como seminários, excursões técnicas e reuniões de estudo e discussões (Souza, 1988).

A extensão não é apenas o elo de ligação entre a pesquisa e os produtores, pois há interferências nas três esferas. Em muitos casos as grandes empresas acabam utilizando a extensão, seja por iniciativa própria ou por intermédio de instituições públicas, para defender seus interesses. Neste sentido, a extensão também pode estar trabalhando em favor do pesquisador. O fomento florestal promovido pela CESP tem buscado atender aos interesses da Companhia (vida útil do reservatório), dos proprietários (alternativa de renda, valorização da propriedade, etc.), ou de ambos? 
Para Freire (1983), qualquer esforço de educação (popular), esteja ou não associado a uma capacitação profissional, seja no campo agrícola ou no industrial urbano, deve ter o objetivo fundamental de, através da problematização do homem-mundo ou do homem em suas relações com o mundo e com os homens, possibilitar que estes aprofundem sua tomada de consciência da realidade na qual e com a qual estão.

"Segundo Mosher, a insistência sobre o aspecto 'educação' na definição do conceito de 'extensão' está relacionada com a experiência dos países onde já existia uma agricultura moderna há bastante tempo. Aliás, de acordo com Swanson \& Claar, as raizes históricas da extensão rural justificam a tal insistência pois, desde o período da Renascença tem havido um esforço para relacionar a educação e os novos conhecimentos científicos com as necessidades cotidianas da vida" (Almeida 1989).

Segundo Barros et al (1998), a ação extensionista que se instalou no Brasil há quase meio século, tinha como principal objetivo a difusão de tecnologia e o dito desenvolvimento do país, através do convencimento persuasivo do produtor rural e do ensino hierarquizado que sobrepunha o saber acadêmico ao popular, de forma que este viesse a aderir às propostas inovadoras da utilização de produtos híbridos, juntamente com toda a indumentária química e mecânica que compunham esse pacote tecnológico. Hoje, destacam os Autores, apesar de um discurso que propõe uma metodologia participativa, inspirada no construtivismo-interacionista, (o foco da Extensão Rural está voltado para os pequenos produtores - clientes prioritários da empresa), a demanda voltase para a transformação da agricultura familiar em agroindústrias, atendendo às exigências de competitividade determinadas pela globalização; uma vez mais a estratégia de marketing é utilizada como meio de despertar no cliente a necessidade da prestação dos serviços da empresa de extensão rural. Sugerem ainda que, a mudança no discurso é apenas uma forma de adaptação, sobrevivência empresarial, e manutenção do sistema, 
concluindo que o serviço extensionista vem mantendo seu foco de ação na mesma direção da promoção do capitalismo.

Galjart (1972) aponta três fatores sociológicos relacionados ao desenvolvimento agrícola e a adoção de tecnologia no Terceiro Mundo:

1- Ignorância (o produtor não sabe fazer outras coisas além daquelas que tem feito até agora);

2- Impotência (ele sabe o que poderia fazer, mas é incapaz de fazê-lo, quer por razões financeiras quer por outras razões);

3- Desinteresse (o camponês sabe o que deveria fazer, e objetivamente pode fazê-lo, mas não quer fazer; certos valores e atitudes o retém; dito de outra forma, ele prefere seguir outro valor).

Ainda segundo Galjart (1972), esta classificação permite distinguir entre diferentes classes de fatores que impedem o desenvolvimento, e que requerem diferentes remédios. A ignorância pode ser combatida com a disseminação de conhecimentos; a impotência com medidas estruturais referentes ao crédito, à comercialização ou à posse e uso da terra; o desinteresse com doutrinação cultural. A classificação, segundo o Autor, também cobre todos os elementos da situação: tanto os naturais quanto os estruturais e os culturais.

De acordo com Queda \& Szmrecsányi (1972), os primeiros órgãos de assistência técnica à agropecuária foram criados no começo do século passado, com a vinda da corte portuguesa para o Brasil, como por exemplo o Jardim Botânico do Rio de Janeiro, fundado em 1808 com finalidades científicas e econômicas. Já em 1860, complementam os autores, foi criado o Ministério da Agricultura, Comércio e Obras Públicas, voltado ao interesse da produção agrícola de uma agricultura baseada no latifúndio e no trabalho escravo. Já no período republicano, o órgão foi reformulado, passando a ser chamado de Ministério dos Negócios da Agricultura, Indústria e Comércio. Queda \& Szmrecsányi 
(1972) destacam que, "essa mudança de nome coincidiu com a preocupação de transferir para a esfera do Estado certas funções regulamentárias e de assistência técnica que até então haviam sido exercidas pelos (grandes) proprietários rurais e suas respectivas associações de classe".

Diesel (1988) destaca que, na literatura distingue-se, para o período anterior aos anos 50, um tipo de política estadual para a agricultura denominada de 'fomento'. As finalidades desta modalidade de assistência técnica, segundo Queda \& Szmrecsányi (1972: p. 270) eram (e continuam sendo): ( a ) o fornecimento de insumos para a produção, isto é, a organização de serviços especializados para a distribuição, ou venda a baixo preço, de sementes, mudas, fertilizantes, inseticidas, etc.; ( b ) a prestação de serviços básicos no que se refere à mecanização agrícola, conservação do solo e da água, obras de irrigação e drenagem, estradas vicinais e outras construções rurais; ( c ) assistência técnica propriamente dita, orientada para determinados ramos da produção vegetal e animal.

Queda \& Szmrecsányi (1972) destacam que cabia ao Estado atender os responsáveis pela produção agropecuária, e que com a crise econômica internacional da década de 1930, alguns empresários agrícolas mais agressivos passaram a influenciar a adoção de políticas agrícolas governamentais destinadas a amparar a produção comercial, especialmente a destinada à exportação. “... a assistência técnica governamental tornou-se permanente para as grandes culturas, e para os grandes produtores que constituíam sua principal clientela. $O$ fomento assim estruturado tem sido criticado por envolver programas de custos sociais elevados e por atingir apenas um pequeno grupo de grandes produtores. Além de ter efeitos educativos limitados, constituía um instrumento político por excelência, na medida que propiciava a distribuição de favores pessoais às custas do erário público. Sua contribuição para melhorar a produtividade do grosso da população rural foi praticamente nula" (Queda \& Szmrecsányi, 1972: p. 271). 
Este tipo de constatação também se verifica no caso do fomento florestal da CESP, visto que identificou-se alguns casos em que os pequenos produtores foram deixados de lado ou esquecidos, como será discutido adiante.

\subsection{Florestas Sociais e o Elemento Arbóreo na Propriedade Rural}

A floresta isolada do ser humano está se tornando inviável com o crescimento econômico, demográfico e com a luta pela posse da terra ou permanência nela por populações tradicionais indígenas, caboclas, e negras, em muitas delas. A idéia de florestas sociais vem ganhando cada vez mais espaço. A floresta não vem mais sendo vista separadamente do ser humano, afinal a espécie humana vem interagindo com a floresta desde que surgiu, há milhares de anos. Ainda hoje existe um grande número de comunidades vivendo na e da floresta, e uma prova do reconhecimento da sua existência está na criação das Reservas Extrativistas, no final da década de 80. Trabalhos como os de Kageyama (1991) e Viana (1991) discutem vários aspectos das reservas extrativistas, mostrando a viabilidade da conservação de florestas aliada a presença de populações humanas nas mesmas.

Segundo Posey (1986), o uso e remanejamento das florestas e savanas tropicais pelos indígenas são melhor entendidos quando vistos como séries contínuas entre plantas que são domesticadas e as que são semidomesticadas, manipuladas ou selvagens, ficando dificil a demarcação explícita entre ecossistemas naturais e remanejados. Ao citar outros pesquisadores e observações próprias, Posey (1986) coloca que grande parte do que tem sido chamado florestas e savanas "naturais" na Amazônia é, possivelmente, o resultado de milênios de remanejamento e co-evolução humanos.

Dentro da perspectiva de florestas sociais, pode se pensar numa integração homem natureza onde, sem esquecer os riscos, as populações das florestas - 
sensibilizadas do seu valor e da necessidade de conservá-las - continuem vivendo nelas e tirando delas parte do seu sustento (subsistência e comércio), e passem a desenvolver ações necessárias à sua recuperação e conservação. Mas, não se pode pensar em comprometer populações, geralmente carentes, na defesa da floresta apelando apenas para idéias abstratas e valores longínquos, tais como a de que a floresta amazônica é o "pulmão do mundo", ou a importância da biodiversidade da Mata Atlântica para a "sobrevivência do planeta". Um planejamento para estas florestas tem que levar em conta sua importância também para a população local e seus descendentes (em termos econômicos, sociais e culturais). As populações tradicionais, além de terem uma visão utilitarista da floresta (influenciada por suas necessidades imediatas), via de regra, vêem a floresta como espaço místico e sagrado (morada dos deuses ou lugar onde estiveram seus ancestrais) e podem passar a vê-la também como reserva biológica, e ter orgulho dela.

O elevado grau de degradação ambiental, a necessidade de se aumentar o leque de alternativas economicamente viáveis para a pequena propriedade rural no nosso país, somado às exigências legais (como área de preservação permanente e área de reserva florestal legal), a princípio, já seriam uma boa justificativa para a adoção de sistemas florestais e agroflorestais nestas propriedades.

Apesar do fato da legislação exigir a presença da árvore na propriedade agrícola, na grande maioria dos casos, o produtor não tem dispensado muito interesse em reservar espaço para as florestas dentro das suas áreas. Em decorrência da colonização européia, o agricultor derruba a floresta com o objetivo de preparar o terreno para as atividades agropecuárias. A adoção de sistemas de produção agrícola que não consideram o elemento arbóreo na propriedade rural é fruto de um processo histórico de ocupação e uso da terra no Brasil. Logo após o descobrimento do Brasil, a principal atividade econômica era o extrativismo do pau-brasil (Caesalpinia echinata Lam.), principalmente, segundo Rizzini (1990), para a produção de corante para tingir tecidos e fabricar tinta de escrever. Com o declínio desta atividade, aponta Szmrecsányi (1990), veio a monocultura 
da cana-de-açúcar, que tomou novo impulso no final do século XVIII, inicialmente no nordeste brasileiro e mais tarde no sudeste; e a do algodão no Maranhão. Este último Autor destaca que neste período o desmatamento era contínuo e chegava a provocar problemas para a própria produção açucareira, que usava a madeira como combustível e teve que substituí-la pelo bagaço da cana. A cafeicultura foi introduzida no Brasil no início do século XVIII e tomou força nas primeiras décadas do século seguinte, no sudeste do país, também na forma de monocultura e acarretando grandes desmatamentos (Szmrecsányi, 1990). Mais recentemente, a monocultura da cana-de-açúcar voltou a crescer no sudeste, mais precisamente no estado de São Paulo, bem como a pecuária extensiva, que ainda é a principal atividade nas áreas de fronteira agrícola.

A árvore, porém, pode trazer inúmeros benefícios para a propriedade rural, entre eles: madeira para diversos fins como construção, fabricação de móveis e utensilios, cabos de ferramentas, moirão de cerca, caixaria para produtos agrícolas e energia; frutos e flores para o consumo próprio e para venda, além da apicultura; conservação do solo e proteção de nascentes e espelhos d'água; paisagismo; quebra-vento; produção de cogumelos comestíveis; agrossilvicultura; sombra; captação de $\mathrm{CO}_{2}$, etc.

Há casos em que o conhecimento e a tecnologia florestal não estão ao alcance dos proprietários rurais, porém também há outros em que informações como estas chegam aos agricultores, inclusive com recursos para a aquisição de mudas e insumos, ficando ele responsável pela mão-de-obra necessária para a implantação e manutenção dos plantios. Mesmo assim, as áreas efetivamente reflorestadas são irrisórias ao se levar em conta a área potencial para esta finalidade.

Por outro lado há exemplos de proprietários que por conta própria decidiram reflorestar parte de suas áreas trazendo benefícios significativos para a produção agropecuária, como no caso da Fazenda Cananéia, no município de Assis-SP. Nesta propriedade, o reflorestamento associado à praticas de conservação de solo, trouxeram 
água em abundância para uma propriedade que no passado não se prestava à pecuária devido a ausência de água para os animais. Outro exemplo é o da Usina Crisciumal, no município de Leme-SP, que há mais de 10 anos vem plantando florestas em áreas de preservação permanente. Estas iniciativas citadas são muito importantes, mas infelizmente não são muito comuns.

A Fundação Florestal, órgão da Secretaria de Meio Ambiente do Estado de São Paulo, lançou em 1993 um Plano de Fomento Florestal Sustentável (PDFS), mas o mesmo não teve continuidade após a mudança de governo. O PDFS tinha o objetivo de fomentar atividades florestais com finalidades econômicas (ex.: plantio de espécies exóticas para a produção de madeira, celulose, etc.) e de conservação ambiental (ex.: restauração florestal em áreas de preservação permanente), e tinha como meta ocupar $25 \%$ do território do Estado de São Paulo com florestas no período de 20 anos. A idéia era fomentar os plantios em áreas impróprias para a agricultura, em função, principalmente, do relevo, tipo de solo, e susceptibilidade à erosão. Para a geração de tecnologia e embasamento teórico foram assinados convênios com universidades e outros órgãos públicos, além de cerca de 70 viveiros particulares para a produção de mudas, com doação de equipamentos, embalagens para produção de mudas, e sementes. Também foi construído um grande centro de produção, beneficiamento e armazenamento de sementes no Instituto de Botânica de São Paulo, mas não foi levado adiante.

O que poderia estar limitando os projetos de restauração florestal? A falha é dos programas de fomento? Nos princípios, diretrizes e objetivos das diversas instituições envolvidas na questão florestal? Nos técnicos que atuam no setor? Nos proprietários rurais? Na legislação vigente? Esta é uma questão que, sem sombra de dúvidas, merece maior atenção, pois aí pode estar a chave para se reverter a situação atual dos programas de reflorestamento no país. 


\subsection{A Situação do Fomento Florestal no Brasil e no Estado de São Paulo}

O setor florestal brasileiro teve grande crescimento a partir da criação da política dos incentivos fiscais aos reflorestamentos no início da década de 70, criada pela Lei Federal $n .{ }^{\circ} 5.106 / 66$ e o Decreto-Lei Federal $n .^{\circ} 1.134 / 70$, e regulamentados pelo Decreto-Lei Federal n. ${ }^{\circ}$ 58.565/71. Foi encerrada com a aprovação da Medida Provisória n. $^{\circ}$ 21/88, pelo Congresso Nacional, que acabou sendo transformada na Lei Federal $n .^{\circ}$ 7.714/88. Após este período, o fomento florestal passou a ter grande importância pelo seu potencial de mitigar alguns equívocos cometidos durante a vigência dos incentivos fiscais, tais como a formação de grandes maciços florestais homogêneos e a exclusão do produtor rural da atividade florestal (Passos, 1996). De acordo com IPEF (1992), os programas de fomento florestal tomaram grande impulso a partir de 1985/86 (fim dos incentivos fiscais), e foram definitivamente incorporados pela legislação através do Decreto 97.628 de abril de 1989 , que permite a inclusão das florestas plantadas no PIFI (Programa Integrado Floresta-Indústria, do IBAMA).

O fomento florestal no Brasil, de acordo com Neves (1994), teve início em 1958 em Minas Gerais através do "Projeto de Reflorestamento para Produtores Rurais", no município de Paraopeba, que na época vivia de um carvoejamento ostensivo e depredatório. A execução deste trabalho teve a participação da EMATER (ex-ACAR) e do IBAMA (ex-IBDF) através da EFLEX. $O$ autor lista diversas experiências florestais que vieram na seqüência: "Projeto de Reflorestamento da Região de Ubá (1963); "Campanha Integrada de Reflorestamento para a Zona da Mata" (1966), que beneficiou 54 municípios; "Campanha Integrada de Reflorestamento do Estado de Minas Gerais" (1968), lançada pelo IEF; "Programa de Reflorestamento de Pequenos e Médios Imóveis Rurais - REPEMIR (1975), lançado pelo IEF e IBAMA; "Programa de Desenvolvimento Integrado da Zona da Mata - PRODEMATA (1977), implementado pelo Governo do estado e pelo BIRD. 
Neves (1994), ao avaliar o fomento florestal do Estado de Minas Gerais desde o início da década de 60 , relaciona como objetivos do fomento florestal o aumento da renda, a conservação do solo e da água, a proteção das matas nativas e da fauna, entre outros beneficios ecológicos, bem como o aproveitamento de áreas erosadas, degradadas, montanhosas, ociosas e improdutivas, incompatíveis para uma agricultura econômica, tecnificada e competitiva. Nestes 35 anos, segundo o Autor, o plantio do eucalipto predominou, mas os produtores que preferiram reflorestar suas propriedades com essências nativas nunca deixaram de ser atendidos. O Autor destaca ainda que, naquele momento, o Instituto Estadual de Florestas estava lançando o "Projeto de Proteção e Recuperação de Matas Ciliares de Minas Gerais", plantio obrigatório de essências nativas e frutíferas regionais. Este Projeto, continua o Autor, veio após o sucesso do Programa de Reflorestamento em nível de propriedade, que por sua vez contribuiu para a conscientização do produtor rural quanto aos beneficios do reflorestamento.

De acordo com o que foi discutido no III Simpósio IPEF - "Silvicultura Intensiva e o Desenvolvimento Sustentável", IPEF (1992), fomento florestal seria uma série de ações protagonizadas por produtores rurais, empresas, poder público e outros, visando a produção de florestas econômicas de baixo custo. Esta mesma fonte cita que, no Brasil, as atividades de fomento à agricultura consideradas bem sucedidas são a produção de fumo, cana-de-açúcar, laranja e outros. Acrescenta ainda que, grandes empresas de produtos avícolas, suínos e bovinos também encontraram seu caminho no incentivo ao produtor rural. Celulose \& Papel (1989) e Ferro (1992), este último através de uma reportagem da revista Silvicultura, mostram duas diferentes iniciativas de empresas florestais, do sul e sudeste do Brasil, visando o fomento florestal. Nestes dois exemplos, o plantio de espécies nativas tem o objetivo de fornecer matéria-prima para as empresas e demais consumidores, inclusive os produtores rurais, diminuir a pressão sobre florestas nativas, aumentar a renda do produtor, valorizar a propriedade, conservar o solo, etc. 
As definições de fomento florestal apresentadas no parágrafo anterior retratam o ponto de vista das grandes empresas de celulose e papel, e indústria madeireira, apoiada principalmente em florestas plantadas com a monocultura de espécies exóticas. Porém, o fomento florestal também pode e deve ter o objetivo de conservação ambiental, através de plantios de várias espécies nativas em consórcio com o objetivo de conservação do solo, da água, da fauna e da flora, dentre outros além da produção de matéria-prima. A conservação da biodiversidade através da restauração florestal é um instrumento importante para a manutenção do equilíbrio ecológico em toda e qualquer propriedade rural, fornecendo alimento e abrigo para inimigos naturais de pragas e doenças, como também para polinizadores que poder vir a aumentar a produtividade agrícola.

Os pontos fortes do fomento florestal, segundo IPEF (1992), são: oferta de produtos florestais a menores custos; nova fonte de renda para os produtores rurais; inclusão das florestas plantadas no PIFI; incorporação de terras ociosas ao processo produtivo, reduzindo a necessidade de aquisição de grandes áreas pelas empresas; melhor distribuição de renda; proteção das reservas nativas e, conseqüentemente, da flora e da fauna; o cultivo mínimo na implantação é facilitado em áreas menores com mão-de-obra local; uso de madeira na propriedade; produção de alimentos na área reflorestada através de consorciação com culturas ou pastagens; contribuição para o desenvolvimento de uma mentalidade florestal com desenvolvimento sustentado; integração dos produtores rurais com as empresas; estimulo ao associativismo e ao cooperativismo na área florestal.

Porém, ao citar os beneficios do fomento florestal apontados no parágrafo anterior, aquela fonte bibliográfica não cita experiências práticas que os comprovem. Não se encontra na literatura exemplos de produtores rurais que tenham obtido tantas vantagens através do fomento florestal praticados pelas empresas do setor florestal.

Os pontos fracos do fomento florestal, ainda segundo o IPEF (1992), são: falta de uma política do Estado que oriente a atividade florestal no país; ausência de informações 
estatísticas que possam contribuir para o estabelecimento de programas pelas empresas; inexistência de fontes de financiamento para a atividade; parte do empresariado ainda não acredita no programa; assistência técnica ineficiente na escolha das áreas a serem reflorestadas, que muitas vezes são inadequadas; inadequação do sistema de escolha do produtor rural participante do programa; falhas no processo de distribuição de insumos e mudas; falta de acompanhamento e orientação técnica ao produtor rural; os tocos remanescentes das sucessivas colheitas desvalorizam a área para novos usos; pouca preocupação com as questões relativas ao meio ambiente nos programas de fomento; desinformação do movimento ambientalista sobre a questão florestal no Brasil, especialmente sobre o fomento florestal; conflito entre os interesses do fomentado e a proteção ambiental, e nas áreas de preservação permanente; dificuldade no controle de incêndios florestais, por problemas de acesso e dispersão das áreas; órgãos públicos desaparelhados e sem recursos para empregar nas atividades de fomento.

O fomento florestal no Brasil é promovido basicamente pelo grande consumidor de matéria-prima florestal (empresas de papel e celulose, siderúrgicas, carvoarias, etc.), e pelas Associações de Reposição Florestal. Em ambos os casos, utiliza-se principalmente espécies arbóreas exóticas, como as dos gêneros Pinus e Eucalyptus. O fomento de espécies florestais nativas tem sido promovido principalmente por instituições ligadas ao poder público, e por organizações não governamentais que atuam na área ambiental.

As Associações de Reposição Florestal são entidades civis, sem fins lucrativos, que congregam pessoas físicas e jurídicas consumidoras de matéria-prima florestal, com um consumo de até 12.000 estéreos de lenha ou 4.000 estéreos de carvão por ano (Andrews, 1991; Passos, 1996).

Segundo Passos (1996), a Portaria n. $^{\circ} 710 / 89$ do IBAMA permitiu a associação de pequenos consumidores, cujo mecanismo de funcionamento baseia-se no sistema utilizado pela conta "Recursos Especiais a Aplicar...", isto é, em vez de recolher a taxa 
ao IBAMA, os recursos são pagos às associações, que fornecem mudas, insumos e assistência técnica aos agricultores, sem quaisquer ônus para estes últimos. Os agricultores são os proprietários dos produtos resultantes do reflorestamento, não havendo compromisso de venda obrigatória às associações ou aos consumidores a elas associados (Andrews, 1991). A Resolução SMA 03/90 da Secretaria do Meio AmbienteSP, que regulamentou o funcionamento das associações no Estado de São Paulo, limitou a um máximo de $5 \%$ os recursos destinados à recuperação de matas ciliares com espécies nativas a partir dos recursos recolhidos pelas associações (Andrews, 1991).

O surgimento das associações de reposição florestal vem de um ato de desobediência civil promovido pela sociedade civil, descontente com o IBAMA (exIBDF) que vinha recolhendo a taxa correspondente ao consumo de matéria-prima florestal dos pequenos e médios consumidores, sem aplicar esses recursos no plantio de florestas comerciais dentro de um raio em que a exploração e o transporte sejam julgados econômicos para os mesmos consumidores, como previa a lei.

A primeira associação de reposição florestal do Brasil foi a "Associação dos Recuperadores Florestais do Vale do Itajar̂, fundada em Ibirama-SC em 1983. No Estado de São Paulo a primeira foi a "Flora Tietê", de Penápolis, em 1986 (Andrews, 1991). Segundo Andrews (1991), a estimativa de plantio para o ano agrícola de 89/90 era de quatro milhões de mudas, somando-se o plantio das oito associações em atividade no Estado de São Paulo na época. Hoje há 18 associações atuando no Estado de São Paulo, das quais apenas 12 estão atuando, com um plantio estimado, pelo DEPRN e Fundo FLORESTAR, de cerca de 7 milhões de árvores no ano de 1999.

\subsection{O Fomento Florestal da CESP}


Segundo Silva (1992), a CESP vem plantando maciços florestais heterogêneos desde 1972/1973, porém só adquiriu a dimensão de programa em 1978, com a criação do Departamento de Recursos Naturais. O Autor informa que o Programa de Recomposição de Matas da CESP tinha, no seu inicio, como principal objetivo o de reflorestar as áreas de empréstimo degradadas pela construção da barragem e sustar o fenômeno de erosão que é altamente nocivo à operação das usinas hidroelétricas. O Autor salienta que, ao longo dos anos, o projeto sofreu uma evolução e foi assumindo uma característica mais ampla de recomposição ambiental, não restrita às alterações provocadas pela construção da barragem.

No início da década de 70, segundo CESP (1993), nos reservatórios da Usina hidrelétrica de Paraibuna (Paraibuna, SP) e U.H.E. Mário Lopes Leão (Promissão, SP), os reflorestamentos da CESP baseavam-se no modelo de plantio com distribuição ao acaso das espécies, resultando em florestas mistas, com longo tempo para consolidação e insucesso de diversas espécies, o que determinou a reavaliação da metodologia. De acordo com a mesma fonte, a partir de 1988 , com o convênio de cooperação entre a CESP e o Departamento de Ciências Florestais da ESALQ (Escola Superior de agricultura "Luiz de Queiroz", da Universidade de São Paulo), procurou-se orientar os plantios para uma concepção de reflorestamento onde se busca o restabelecimento da estrutura e dinâmica da comunidade florestal através dos princípios da sucessão secundária, descrita por Budowski em 1965. Porém, é importante destacar que Budowski (1965), ao estudar a regeneração natural, em períodos de tempo conhecidos, em áreas que sofreram alterações antrópicas no passado, descreveu quatro estágios da sucessão secundária pelos quais a floresta passa, e não os princípios da sucessão secundária.

A CESP (Companhia Energética de São Paulo) desenvolve vários programas visando a conservação ambiental, voltados à melhoria da qualidade e quantidade de água de seus reservatórios. Fazendo parte destes programas destacam-se, como importantes atividades, a reprodução de peixes regionais e o repovoamento de bacias hidrográficas, 
além da produção de mudas de espécies vegetais nativas e da implantação de reflorestamentos nas margens dos reservatórios das usinas hidrelétricas, suas respectivas ilhas e tributários. Para isso, possui 5 viveiros de produção de mudas de essências nativas no Estado de São Paulo, que estão localizados em: Paraibuna, Porto Primavera, Ilha Solteira, Jupiá, e Promissão (CESP, 1997). Tais viveiros produziam, em 1993, cerca de 8,5 milhões de mudas de essências nativas/ano, trabalhando com aproximadamente 500 espécies, onde estão representados todos os extratos vegetais (ervas, arbustos e árvores), e também todos os estágios sucessionais (CESP, 1993).

Segundo CESP (1993), os trabalhos de reflorestamento, nas áreas de influência dos seus reservatórios, vêm sendo executados através de dois programas distintos: a) Programa de recomposição de matas ciliares e recuperação de áreas degradadas (empréstimos), desenvolvidos em áreas da Companhia, pela própria CESP; b) Programa de recomposição de matas ciliares, através do Fomento Florestal. Este programa é desenvolvido em terras de particulares, onde a CESP fornece as mudas e a orientação técnica e o proprietário incumbe-se do plantio e da condução do reflorestamento. Através desses dois programas citados no parágrafo anterior, já haviam sido implantados cerca de 10.000 ha de áreas marginais (CESP, 1993).

No início da década de 80, o fomento da CESP sugeria a possibilidade de manejo para fins econômicos das faixas reflorestadas nas margens de seus reservatórios e tributários, o que mais adiante foi revisto e retirado do programa. "O Plano de Fomento Florestal consiste basicamente do seguinte: a CESP elabora os projetos de revestimento vegetal de uma faixa tecnicamente aceitável ao redor dos reservatórios; tal faixa, além das características voltadas à defesa do meio ambiente, admite um uso econômico parcial, possibilitando aos lindeiros obter um rendimento adicional a partir de áreas hoje ociosas. A seguir a empresa fornece orientação técnica de campo e as mudas adequadas ao projeto. Por conta dos particulares fica a mão-de-obra para a implantação, manutenção e exploração controlada da área" (Fernandes 1985). 
Recomposição florestal foi o termo inicial utilizado, não apenas pela CESP, mas generalizadamente no Brasil para as ações de reflorestamento misto com espécies nativas. Com o tempo o termo foi sendo reelaborado, passando a restauração florestal, seguindo a terminologia internacional. De acordo com Engel (1999), quando a recomposição florestal se preocupa mais com a estrutura, e não necessariamente com o funcionamento do ecossistema ou comunidade, está-se falando em recuperação de áreas degradadas. Neste caso, continua a Autora, o ecossistema original não é necessariamente usado como referência, e a dinâmica futura não é uma preocupação. Já a restauração, procura retornar uma porção degradada da paisagem a uma condição mais próxima possível da original, tanto no aspecto estrutural quanto funcional do ecossistema de forma a permitir que uma comunidade evolua e a sucessão natural ocorra (Engel, 1999).

No material de divulgação do seu Programa de Fomento Florestal, utilizado até a finalização da coleta de dados do trabalho, a CESP vinha utilizando o termo recomposição de matas ciliares. "O Programa de Fomento Florestal é uma proposta de parceria entre a CESP e proprietários rurais e/ou empresas, com o objetivo de recompor as matas ciliares de proteção aos seus reservatórios e às nascentes, córregos e rios que neles deságuam. A parceria é feita através de um Contrato de Cooperação Recíproca, em que a CESP se compromete a fornecer o projeto técnico, dotado dos mais avançados modelos de reflorestamento, a assistência técnica total, com técnicos experientes e prontos para melhor orientar os parceiros, e a doação de mudas de essências florestais nativas, com alta diversidade de espécies (flores, frutos, madeira, importância ecológica, etc.) além do reconhecido padrão de qualidade. Ao proprietário caberá apenas o plantio e a condução do reflorestamento" (CESP, "Fomento Florestal: CESP e você, juntos, conservando o meio ambiente", apresentado em anexo como Apêndice 1).

Kageyama \& CESP (1992), ao abordar o fomento florestal da CESP, apresentam as mesmas informações já citadas no parágrafo anterior, e enfatizam que a metodologia 
adotada nos projetos de fomento é basicamente a mesma empregada nos projetos executados exclusivamente pela CESP.

Sobre as vantagens que o fomento florestal traz à CESP, Kageyama \& CESP (1993) destacam que, a Companhia tem conseguido diluir os custos de programa de recomposição vegetal, assim como motivar os proprietários para a conservação ambiental, além de reduzir a sua presença direta.

Um resumo de como se desenvolve o Programa de Fomento Florestal da CESP, desde o primeiro contato com o produtor é descrito por Kageyama \& CESP, (1992): “O programa de fomento tem início quando o proprietário rural manifesta interesse na cooperação recíproca, informando o nome da propriedade, município, reservatório e/ou tributário, área a ser recomposta, vias de acesso e endereços para contato. Em seguida, a propriedade é visitada por técnicos da CESP para reconhecimento da área e avaliação dos recursos disponíveis para implantação do projeto. Uma vez confirmada que a área visitada reúne condições satisfatórias para a implantação do fomento, tem início a elaboração do anteprojeto, a partir do qual, considerando-se também as facilidades existentes na propriedade, é preparado o projeto executivo. Com as informações do projeto é elaborado o "Instrumento Particular de Contrato de Cooperação Recíproca para Implantação de Projeto de Reflorestamento Ciliar", apresentado no Apêndice 6. O critério da sucessão secundária induzida ${ }^{1}$, empregado pela Companhia em seus plantios de recomposição de matas, também é adotado no programa de fomento".

De acordo com Fernandes (1985), no trabalho intitulado "Plano de Fomento Florestal da CESP", definido o polígono de desapropriação necessário à formação do reservatório, prevalece a necessidade de que a empresa consiga manter desimpedida a área lindeira ao contato com a água, tanto por razões de segurança operacional, como pela necessidade de proteger a bacia contra assoreamento, e para que tais margens 
possam ser trabalhadas em termos de meio ambiente. Ocorre que, continua o Autor, nem sempre a empresa tem conseguido manter de fato o domínio sobre tais áreas, como também não tem conseguido adequadamente protegê-las, pelo alto custo de tais obras. Nesta época, o custo de cada hectare reflorestado pela CESP com espécies nativas girava em torno de US\$ 4,500.00 (quatro mil e quinhentos dólares), como informam Kageyama \& Gonçalves (1997: I. 12).

Como uma das alternativas para aumentar a área efetivamente plantada às margens de seus reservatórios, revela Fernandes (1985), o "Plano de Fomento" da CESP procuraria induzir na população lindeira o espírito conservacionista, com base nos fatos de que a área perimetral dos seus reservatórios atinge cerca de $15.000 \mathrm{~km}$, distância essa que supera em muito a própria costa atlântica brasileira, e de que sozinha, e ao ritmo atual, segundo as projeções, levaria um ou dois séculos para proteger todos os entornos dos seus lagos artificiais.

Ao falar sobre o Programa de Fomento Florestal da CESP, Silva (1990) considera que o projeto, a exemplo de outros como o Programa Eucalipto e o Programa Metanol, sofre um tratamento marginal, em desacordo com a potencialidade que ele apresenta. $\mathrm{O}$ Autor citado acrescenta que essa seria uma das formas mais eficientes não só de ampliar a área de recomposição, como também aumentar o ritmo e diminuir o custo operacional do Programa de Recuperação de Matas da empresa. Ainda segundo aquele autor, isso implicaria em uma mudança de concepção, pois gerir o programa fora dos limites de propriedade da empresa e eventualmente atribuir-lhe uma possibilidade de manejo, o que funcionaria como um atrativo para esses proprietários, ainda é uma idéia pouco discutida.

Para sustentar a idéia de que o Programa de Fomento Florestal da CESP recebe um tratamento de menor importância, Silva (1990) apresenta uma citação de um técnico da empresa entrevistado, dizendo que a destinação de mudas para esse fim é de apenas

\footnotetext{
' A expressão "sucessão secundária induzida" significa no texto auxilio à sucessão natural.
} 
2,5\% da produção dos seus viveiros. 90,0\% é para a recomposição de matas nativas em áreas de propriedade da empresa, 5,0\% para arborização urbana, e 2,5\% para projetos paisagísticos.

\subsection{0 modelo de plantio misto de espécies nativas da CESP (Modelo CESP)}

Ao longo de mais de duas décadas, a Companhia Energética de São Paulo (CESP) vem acumulando experiência no plantio de espécies florestais nativas, no entorno dos reservatórios de suas usinas hidrelétricas e margens de rios que neles deságuam. Neste período, a empresa investiu em pesquisas e parcerias com outras instituições, gerando uma tecnologia de recomposição florestal reconhecida internacionalmente. $O$ maior avanço se deu, certamente, a partir do final da década de 80, com o estabelecimento do Convênio de Cooperação CESP-ESALQ-IPEF, sob coordenação do Prof. Dr. Paulo Kageyama (ESALQ/USP), grande inspirador e motivador do convênio, atualmente na sua terceira, e talvez última, versão. Nestes dez anos o convênio contou com a participação de outros professores, pesquisadores e estudantes da ESALQ, e um corpo técnico de excelente qualidade pelo lado da CESP.

Ao analisar a evolução do Programa de recomposição de Matas da CESP, desde seu início em 1972/1973 até 1990, Silva (1992) destaca que a partir de 1988 o programa entrou no que ele denominou de Fase Científica. De acordo com o autor, sua característica principal tem sido a busca de uma metodologia de implantação de matas nativas a partir de um instrumental científico mais amplo, e para isso a CESP estabeleceu um convênio com a USP-ESALQ-IPEF e outro com a USP-Instituto de Biociências. Antes desta fase, ressalta Silva (1992), o programa estava organizado de uma forma que ignorava conceitos básicos de fitossociologia e sucessão secundária. Como critério de seleção das espécies, além da ocorrência regional e da diversidade, havia uma preferência 
por espécies de alto valor econômico. O Autor ilustra este último ponto da seguinte forma: "Já que é para plantar, por que não plantar o melhor?". Plantando-se preferencialmente espécies de alto valor madeireiro, espécies de importantíssimo valor ecológico, mas sem valor comercial expressivo, eram deixadas de fora.

O Convênio CESP-ESALQ-IPEF gerou conhecimentos utilizados largamente pela CESP em seus plantios e estimados em cerca de 500 hectares a cada ano; o programa foi difundido em sala de aula para os alunos da ESALQ/USP, além de ter dado oportunidade de estágio para os estudantes, e gerado dezenas de artigos apresentados e publicados em diversos congressos, revistas e outros meios de comunicação. $O$ "modelo CESP de revegetação" é, sem sombra de dúvidas, a grande referência nacional para plantios mistos de espécies arbóreas nativas.

Segundo Kageyama \& CESP (1992), procurou-se considerar, no trabalho de reflorestamento misto para proteção dos reservatórios da CESP, alguns aspectos fundamentais à auto-renovação das florestas implantadas. Esses aspectos foram assim listados: diversidade de espécies, variabilidade genética nas populações, distribuição espacial dos indivíduos, polinização e dispersão de sementes, formação de banco de sementes das espécies pioneiras e sucessão secundária.

A tecnologia desenvolvida pela CESP baseia-se na dinâmica da floresta tropical, e portanto é direcionada para áreas de domínio desta forma de vegetação, não sendo aplicada a outras formações vegetais, como por exemplo o cerrado, a caatinga, o mangue, a restinga e os campos de altitude.

Vários autores propuseram diferentes sistemas para a classificação das espécies da floresta tropical em grupos ecológicos. A CESP adotou a terminologia proposta por Budowski (1965), que consiste em quatro grupos, a saber: pioneiras, secundárias iniciais, secundárias tardias e clímax (Kageyama \& CESP, 1992; CESP, 1993). 
Em artigo apresentado em um curso de recuperação de área degradadas, a CESP (1993) destaca que: "os projetos de recomposição da vegetação natural nas bordaduras dos rios e lagos têm como princípio básico o uso de espécies vegetais pertencentes a estágios sucessionais distintos, manejados com $o$ propósito de favorecer $o$ estabelecimento da dinâmica da sucessão natural. Nessa combinação, grupos de espécies com exigências complementares, principalmente quanto à necessidade de luz, são associados de tal forma que as espécies de estágios iniciais (pioneiras) sejam sombreadoras das espécies de estágios finais (secundárias e clímax), recobrindo rapidamente a área, tutorando o crescimento, debilitando as gramíneas, promovendo o intercâmbio de sementes, etc. Em síntese, os projetos de recomposição de matas ciliares, implementados pela CESP, fundamentam-se nos mecanismos naturais que as florestas tropicais desenvolveram para sua auto-regeneração".

Nos plantios da Companhia, a CESP desenvolveu modelos de plantios que procuram acelerar o tempo que seria necessário para a restauração da área. Sobre este tema, encontra-se em CESP (1993) a seguinte explanação: "nas florestas tropicais, a recuperação das lesões provocadas pela abertura de clareiras ocorre de maneira gradativa, ou seja, primeiro instalam-se as espécies pioneiras, criando condições para o desenvolvimento (germinação) das espécies secundárias e essas, por sua vez, realizam a mesma função para as espécies de estágio clímax. Porém esses fenômenos podem levar muito tempo, dependendo principalmente dos mecanismos de dispersão (vento, animais, água, etc.). Deste modo, procurando diminuir o tempo de recuperação ambiental das áreas, os modelos de implantação utilizados pela CESP contemplam todos os estágios sucessionais simultaneamente no ato do plantio. Esses plantios são realizados em linhas, obedecendo o nível do terreno, alternando-se nas linhas os estágios iniciais e finais".

A CESP, certamente, é a instituição que mais vem plantando florestas mistas de espécies nativas no Brasil. Como se pode ver em Kageyama \& Gonçalves (1997) e IPEF 
(1999), o custo de plantio do modelo de reflorestamento utilizado pela CESP até meados da década de 80, que usava mudas plantadas ao acaso e sem uso de espécies Pioneiras, era cerca de US\$4.500,00/ha. Hoje, com o plantio segundo a sucessão e com o uso de Pioneiras, o custo é de cerca de US\$ 1.500,00/ha. Kageyama \& Gonçalves (1997) destacam que, para isso, foram implantados muitos experimentos para se comprovar a existência dos grupos ecológicos e se testar as várias combinações entre eles. 


\section{METODOLOGIA}

O aluno de "ciências ambientais", que une conhecimentos da área biológica e das ciências sociais, enfrenta muitas dificuldades para elaborar um projeto de pesquisa, devido a falta de bibliografia, informações, documentos e registros. Isso se deve ao fato de ser esta uma área recente e sem tradição no Brasil, e muitas vezes há a necessidade de se produzir alternativas, para obtenção de dados, e analisar tendências. No estudo ora apresentado não foi diferente, pois havia pouca informação registrada nos arquivos da CESP sobre o seu Programa de Fomento Florestal. Antes da consulta aos arquivos do viveiro da companhia, em Porto Primavera, imaginava-se que havia grande volume de informação sobre as propriedades fomentadas, mudas enviadas e desenvolvimento dos plantios, mas durante o desenvolvimento dos trabalhos constatou-se que não houve uma preocupação nesse sentido.

O primeiro trabalho que serviu de base, não só para a definição da metodologia, mas também para a elaboração inicial do plano de pesquisa, foi um texto de orientação não publicado e elaborado pelo Professor José Eli da Veiga, da FEA e do PROCAM intitulado: "Como transformar seu plano de trabalho em projeto de pesquisa". Foi a partir do contato com esta obra que passou-se a pensar mais seriamente com o que Veiga (1995), chamou de "descrição dos procedimentos", que o Autor destaca como "... previstos na procura das evidências que possam confirmar, ou não confirmar, a hipótese".

A obra "Repensando o Sincretismo", do Professor Sergio F. Ferretti, foi uma importante fonte de inspiração para a definição da metodologia a ser adotada. Na Parte 1, 
"Considerações sobre a Metodologia de Pesquisa", o autor cita problemas por ele enfrentados em suas pesquisas, e fornece sugestões: "Uma das condições para um bom trabalho de campo em antropologia é saber fazer o outro falar. Uma dificuldade daí decorrente é delimitar adequadamente o que se pode ou não divulgar do material coletado. É preciso colocar as pessoas à vontade, com simplicidade e naturalidade, $e$ depois decidir que aspectos se deve divulgar ou não" (Ferretti, 1995: p. 27 e 28); "Desvendar problemas pessoais é um dos riscos que é preciso ter o cuidado de contornar, para não trazer obstáculos aos informantes..." (Ferretti, 1995: p. 28). "Mesmo que o caso seja discutido apenas em publicaçães restritas ao meio acadêmico, corre-se sempre o risco de tais informações extrapolarem este campo..." (Ferretti, 1995: p. 29).

\subsection{A proposta inicial de trabalho}

Quando da elaboração do plano de trabalho da dissertação, a proposta de trabalho consistia em: avaliar os plantios mistos de espécies nativas em propriedades rurais, atendidas pelo fomento florestal da CESP, na unidade de Porto Primavera, tendo como referência os reflorestamentos implantados nas áreas da própria empresa; identificar possíveis causas do sucesso ou insucesso dos reflorestamentos nas propriedades particulares fomentadas; conhecer melhor o desenvolvimento das diferentes espécies utilizadas nos plantios, bem como dos diferentes grupos sucessionais (pioneiras, secundárias iniciais, secundárias tardias, e climácicas, na classificação feita por Budowski, 1965) e as relações entre eles; fornecer elementos que poderiam contribuir para melhorar o programa de fomento da CESP; identificar as razões que levaram os produtores rurais a participar do programa de fomento da empresa, e se estes pretendiam fazer algum uso, econômico ou não, dos plantios; recuperar os conhecimentos florestais do agricultor; pesquisar novas opções econômicas para pequenas e médias propriedades que incluíam 
plantios mistos de espécies arbóreas nativas; recolher informações dos produtores rurais que poderiam ajudar na elaboração de modelos de reflorestamentos adequados às necessidades e possibilidades da pequena propriedade rural; estimular a atividade florestal em pequenas propriedades para fins de proteção e produção.

Para o desenvolvimento do projeto, o autor contou com uma bolsa de mestrado concedida pela CAPES, ao Departamento de Ciências Florestais da ESALQ/USP, e a ele repassada pelo período de 18 meses.

O modelo de reflorestamento da CESP foi elaborado para ser implantado em áreas da empresa e com o objetivo de proteção (conservação do solo e revegetação do entorno dos seus reservatórios), mas depois também foi utilizado no programa de fomento, que além da proteção também chegou a ter o objetivo de produção, com as devidas restrições, como foi apresentado no capítulo 2.3 (O Fomento Florestal da CESP).

Em visitas às áreas de plantio da CESP, em diversas regiões do Estado de São Paulo, bem como através de revisão bibliográfica e consulta a material de divulgação da empresa, entre outros, constatou-se que a Companhia vinha desenvolvendo um trabalho de excelente qualidade, possuindo equipamentos e equipes devidamente treinadas para as atividades florestais. Porém, isso em áreas próprias do Estado. Quanto aos plantios realizados em propriedades particulares por intermédio do Programa de Fomento Florestal da empresa, não havia quase informação.

Surgiram, então, perguntas como: a qualidade do plantio é a mesma em áreas do Estado e em áreas particulares? A mão-de-obra utilizada pelos fomentados para o plantio e manutenção das florestas era ou não qualificada para a atividade, e isso teria influência na qualidade destes plantios? Qual é a avaliação que o produtor faz do plantio em sua propriedade? $\mathrm{O}$ produtor ficou ou não satisfeito com o resultado obtido até o momento? Quais as impressões dos lindeiros sobre este Programa de fomento florestal? Quais os 
motivos que o levaram a fazer o reflorestamento? Ele fez a manutenção na área plantada ou deixou-a de lado, e por que motivo? As árvores sobreviveram ou não?

Para desenvolver o estudo, contatou-se o Chefe do setor de Ecossistemas Paranapanema - MIFP, e o Chefe da Seção de Silvicultura de Primavera - MIFPS, a quem foi apresentada a idéia e o pedido de autorização para realização do mesmo. A orientação, dada por eles, foi a de redigir um plano de trabalho contendo uma pequena revisão bibliográfica $\mathrm{e}$ as idéias apresentadas acima, e encaminhá-lo juntamente com uma carta de apresentação e intenções ao Diretor de Meio Ambiente da CESP (Anexo A), onde deveria estar bem claro que não haveria nenhum ônus para a CESP. Em resposta à esta solicitação, foi concedida uma carta autorizando o desenvolvimento do trabalho (Anexo $B)$. Foi pedido que fosse comunicada previamente toda e qualquer visita a campo, e que lhes fosse enviado o trabalho final. Também foi sugerido a consulta de publicações mais recentes que abordam o fomento florestal praticado pela CESP, com o intuito de melhor conceituá-lo, visto que a bibliografia utilizada até então, (Fernandes, O. R. 1985), não refletia com exatidão o trabalho atual da empresa. Todo este processo durou cerca de 5 meses.

\subsection{0 trabalho realizado}

Em setembro de 1997, foi realizada uma visita ao viveiro de produção de mudas de Porto Primavera e a alguns plantios, em diferentes fases de desenvolvimento, em áreas da CESP e de lindeiros. Foi quando constatou-se que seria muito dificil desenvolver o trabalho que havia sido imaginado. As áreas de plantio eram muito distantes umas das outras e, conseqüentemente, muito distintas também. Havia muita diferença entre os plantios, pois possuiam diferentes idades, espécies, espaçamento de plantio, tratos culturais. Alguns foram feitos em áreas úmidas e outros em áreas mais secas, e até 
mesmo os solos e o clima não eram os mesmos. Compará-los seria muito complicado. Além do mais, o interesse maior deste trabalho era o de identificar o que havia levado os produtores fomentados a participar, ou desistir, do Programa de fomento florestal da CESP, e como avaliavam o Programa, além de registrar possíveis sugestões e reivindicações destes produtores, que poderiam contribuir para o aprimoramento do Programa. Assim, desistiu-se de acompanhar o desenvolvimento silvicultural das árvores plantadas tanto nas propriedades rurais fomentadas pela CESP, quanto nas da empresa.

Mesmo depois das mudanças relatadas no parágrafo anterior, foi elaborado um formulário de avaliação rápida dos plantios realizados pelo Programa de Fomento Florestal da CESP, com o propósito de fazer um rápido levantamento da qualidade dos plantios das propriedades fomentadas. A intenção era a de visitar algumas propriedades e fazer esta avaliação em uma rápida caminhada pelo plantio, sem a necessidade da presença do proprietário ou funcionário responsável. Como havia sido levantado que boa parte dos proprietários não residiam na propriedade fomentada, e que muitos eram de cidades muito distantes e até mesmo de outros Estados, era necessário um instrumento de avaliação que permitisse a coleta de informações, que não exigisse a presença de terceiros, e que pudesse ser executado por uma única pessoa, no caso o próprio pesquisador. Este instrumento de avaliação, que não chegou a ser utilizado no trabalho, encontra-se no Apêndice 2.

Em fevereiro de 1998 retornou-se a Porto Primavera com o objetivo de levantar todas as propriedades fomentadas pelo viveiro desde o início do Programa, em 1988, até dezembro de 1997. Para isso consultou-se os arquivos do Programa de Fomento daquela unidade da CESP durante uma semana. Havia uma pasta aberta para cada contrato de fomento, onde deveria estar armazenado todo o histórico daquele contrato, como cópia da solicitação de mudas e do contrato de cooperação, etc. Porém, em alguns casos, principalmente nos contratos mais antigos, não havia cópia do contrato, nem mesmo do pedido de mudas. Também não foi encontrado o registro das espécies enviadas para cada 
propriedade. Apesar disso, durante este período, presenciou-se a expedição de mudas para contratos de fomento em vigor, onde o proprietário recebia uma listagem das mudas, com o nome comum, a quantidade, o grupo ecológico de cada espécie, e um esquema simplificado do modelo de plantio.

Mesmo antes do levantamento total de contratos de fomento florestal, imaginavase que seria necessário reduzir o universo de pesquisa para uma determinada região do Estado de São Paulo, com características fundiárias, culturais e socioeconômicas, aparentemente, não tão diferentes quanto se comparada à totalidade dos contratos, que inclusive ultrapassava a divisa com outros estados. Assim, estes municípios foram organizados segundo a classificação da Coordenadoria de Assistência Técnica Integral (CATI), da Secretaria da Agricultura e Abastecimento, que divide o Estado de São Paulo em 40 Escritórios de Desenvolvimento Rural (EDRs), também chamadas de Regionais da CATI. Em média, cada EDR contem de 15 a 20 municípios.

Havia sido elaborado, alguns meses antes, um questionário de entrevista ao proprietário rural fomentado (Apêndice 3), outro para os funcionários da CESP, envolvidos no Programa de Fomento Florestal da empresa (Apêndice 4), e uma ficha de cadastro da propriedade fomentada (Apêndice 5) para controle, que seria preenchida pelo próprio pesquisador, com base nos dois questionários citados acima e nos arquivos da CESP. Nenhum dos três instrumentos chegou a ser utilizado, mas seus conteúdos acabaram servindo como base para a elaboração de formulário de pesquisa a ser apresentado adiante.

Havia uma grande dificuldade em se fazer o contato entre o pesquisador e os produtores fomentados pela CESP, visto que parte deles não reside na propriedade rural, residindo em outros municípios, e vindo esporadicamente à propriedade. Outro agravante é o fato de que as propriedades atendidas pelo fomento da Companhia eram muito distantes umas das outras, como havia sido alertado pela equipe técnica responsável pelo 
fomento. Desta forma, visitas às propriedades exigiria muito tempo e recursos financeiros não disponíveis.

Ao invés de entrevistar pessoalmente alguns produtores ao acaso, optou-se pela elaboração de formulários de pesquisa para serem enviados pelo correio a todos aqueles que tivessem contrato de fomento com a CESP, excluindo-se aqueles que estivessem em nome de órgãos públicos, como prefeituras e escolas, e os que não apresentassem endereço para correspondência.

\subsection{Coleta de dados: a opção por formulários de pesquisa}

O Programa de Fomento Florestal, do Viveiro da CESP de Porto Primavera, conta basicamente com 5 profissionais: o Chefe do setor de Ecossistemas Paranapanema - MIFP; o Chefe da Seção de Silvicultura de Primavera - MIFPS (responsável pela elaboração do Projeto Técnico de reflorestamento); dois Técnicos de Meio Ambiente (responsáveis pelo viveiro e expedição das mudas); e um Auxiliar Administrativo. O Programa de Fomento consiste nas seguintes etapas:

1- Divulgação: a CESP informa os proprietários de terras nas áreas de influência de seus reservatórios, sobre a existência do Programa de Fomento Florestal, através de folhetos (ver Apêndice 1), dias de campo, cartas enviadas juntamente com a conta de energia elétrica, palestras, e visita diretamente ao local.;

2- Solicitação: o proprietário interessado entra em contato com a CESP, por telefone, Fax, correio, ou pessoalmente, informando o nome, o município e a localização da propriedade com indicação de como chegar ao local, telefone, e nome de uma pessoa para contato; 
3- Visita ao local: a partir da solicitação do proprietário, a CESP faz uma visita ao local para recolher informações técnicas necessárias para a elaboração do projeto técnico de reflorestamento;

4- Contrato: o proprietário e a CESP assinam um contrato de cooperação recíproca para implantação de projeto de reflorestamento ciliar, em três vias, ficando uma com o proprietário e duas com a CESP uma no arquivo da empresa em São Paulo e outra no arquivo do viveiro (ver modelo do contrato que estava sendo utilizado em Fevereiro de 1998 apresentado no Apêndice 0);

5- Expedição: saída das mudas do viveiro para a propriedade fomentada. Normalmente são enviadas $50 \%$ de mudas de espécies de rápido crescimento e $50 \%$ de crescimento mais lento, ou a alternativa de $2 / 3$ e 1/3 respectivamente. As mudas também são divididas em espécies de área úmida, plantadas em áreas mais próximas da água ou sujeitas à inundação, e espécies de área seca.

Para facilitar o manuseio dos contratos de fomento, a área administrativa da CESP de Porto Primavera separou-os em três grupos a saber:

a) Vigentes: contratos que ainda estão no período de vigência, que na maioria dos casos é de 4 anos, independentemente das mudas terem sido retiradas ou não;

b) Vencidos: contratos em que o período de vigência já terminou, mesmo que as mudas não tenham sido retiradas do viveiro;

c) Desistentes: contratos que não foram assinados, por desistência da CESP ou do proprietário.

Baseado na classificação acima, adotada pela própria CESP, elaborou-se três formulários de pesquisa distintos (Anexos, $C, D$ e $E$ ), para serem enviados pelo correio (um para cada contrato de fomento), para atender a três públicos diferentes:

a) PÚBLICO 1 (contratos de fomento classificados como vigentes e vencidos)

Público alvo: Propriedades que participam ou participaram do Programa de Fomento Florestal da CESP. 
Objetivo: Identificar os motivos que levaram os produtores rurais incentivados pela CESP, na região do reservatório de Porto Primavera, a plantar floresta nativa em sua propriedade, recuperando a forma como o produtor ficou sabendo do Programa de Fomento Florestal da CESP, e o grau de participação do produtor na tomada de decisão, além de avaliar o Programa de Fomento (incentivo) Florestal da Companhia.

b) PÚBLICO 2 (contratos de fomento classificados como desistentes)

Público alvo: Propriedades que após um contato inicial com a CESP, desistiram de participar do Programa de Fomento Florestal da Companhia.

Objetivo: Identificar os motivos que levaram os produtores rurais incentivados pela CESP, na região do reservatório de Porto Primavera, a plantar floresta nativa em sua propriedade; a desistir do contrato, recuperando a forma como o produtor ficou sabendo do Programa de Fomento Florestal da CESP; e o grau de participação do produtor na tomada de decisão; além de avaliar o Programa de Fomento (incentivo) Florestal da Companhia.

c) PÚBLICO 3 (propriedades não cadastradas no Programa de Fomento do Viveiro) Público alvo: Propriedades que até o momento não participaram do Programa de Fomento Florestal da CESP.

Objetivo: Avaliar a divulgação e o potencial do Programa de Fomento (incentivo) Florestal da CESP, na região do reservatório de Porto Primavera; e o interesse deste grupo de proprietários rurais por atividades florestais.

Nos formulários de pesquisa utilizou-se apenas de questões de múltipla escolha, sendo algumas comuns aos três formulários: PÚBLICO 1 (Anexo C); PÚBLICO 2 (Anexo $D$ ) e PÚBLICO 3 (Anexo $E$ ). Os formulários foram enviados em um envelope contendo também uma carta e outro envelope para resposta já endereçado e selado. Esta carta (Anexo $F$ ) apresentava o trabalho que estava sendo desenvolvido, explicava o propósito do formulário de pesquisa, e passava orientações de como preenchê-lo. 
O primeiro programa de fomento florestal realizado pelo viveiro de mudas, de Porto Primavera, foi em 1988. Porém, só a partir de 1996 foi adotado o procedimento de se preencher uma ficha completa com os dados do proprietário e da propriedade fomentada, o que não tem sido seguido à risca. Apresentamos em anexo um modelo de ficha que foi desenvolvido em 1997, mas que ainda não estava sendo utilizado até fevereiro de 1998 (Apêndice 7). Os formulários possuem um espaço para o preenchimento do nome do proprietário, nome e tamanho da propriedade, endereço e telefone para contato, com o intuito de se confirmar e atualizar estes dados. $\mathrm{O}$ tamanho da propriedade deveria ser registrado com precisão para que se pudesse agrupá-las em classes de tamanho de área. Isso porque havia a hipótese de que pequenos, médios e grandes proprietários poderiam dar respostas diferenciadas às perguntas, o que, se fosse confirmado, indicaria que a CESP deveria tratá-los de forma diferenciada.

Em todos os formulários também perguntou-se através de quem, ou por meio de que instrumento, o proprietário ficou conhecendo o Programa de Fomento Florestal da CESP, para que se pudesse avaliar a divulgação do Programa pela CESP, e os canais mais eficientes neste processo, para que no futuro possam ser melhor explorados. Todos eles continham questões sobre o nível de proteção arbórea nas margens de córregos, rios, lagos e nascentes da propriedade; sobre a existência, tamanho e estado de conservação de eventuais fragmentos de mata existentes na propriedade; e sobre o interesse em adotar uma ou mais de uma lista de cerca de 15 alternativas de atividades florestais, sugeridas para sua unidade de produção agropecuária. Estas questões procuravam identificar o potencial das atividades florestais a ser explorado por este ou outro programa florestal na região, e o lugar destinado pelo produtor ao elemento arbóreo em sua propriedade. Considerou-se, neste estudo, de fundamental importância levantar se os produtores viam a possibilidade, ou tinham interesse, em ter a árvore como uma alternativa produtiva e/ou de proteção ambiental, para que se pudesse enriquecer o repertório técnico do extensionista de forma a contemplar a demanda dos produtores rurais. 
Para os PÚBLICOS 1 e 2, perguntou-se o motivo que os levou a plantar ou querer plantar árvores em suas propriedades, com o objetivo de identificar o grau de comprometimento do produtor com o elemento arbóreo. As alternativas variavam desde a obrigação legal, passando por reserva de produtos florestais, paisagismo, conservação do solo e de recursos hídricos, abrigo para animais e controle de pragas, mudas e assistência técnica gratuitas, até a de seguir o exemplo de vizinhos. Finalizando foi reservado um espaço para outras alternativas por eles levantadas. Conhecendo os principais motivos que têm levado os produtores de uma determinada região a plantar árvores nativas, pode-se desenvolver e aprimorar alternativas diferenciadas e mais adequadas para cada tipo de interesse.

Ainda nos formulários elaborados para os PÚBLICOS 1 e 2, perguntou-se: havia sido feito algum tipo de reflorestamento sem a parceria com a CESP; como o proprietário avaliava o Programa de Fomento Florestal da empresa e se o mesmo teria algum comentário a mais sobre o Programa. Com isso, objetivou-se identificar a iniciativa daqueles produtores em buscar outras alternativas para realizarem reflorestamentos em suas áreas, e qual a sua avaliação e possíveis sugestões para melhorar o Programa.

Especificamente para o PÚBLICO 1, elaborou-se uma questão sobre a mão-deobra utilizada, desde a abertura das covas e plantio até a manutenção do povoamento, classificando-a em familiar, funcionários da propriedade, mão-de-obra contratada para o serviço específico, ou outro tipo. $\mathrm{O}$ uso de mão-de-obra familiar e de funcionários que já trabalham na propriedade pode significar um deslocamento de função, o que pode não ser possível em determinadas épocas do ano, ou depende da quantidade de mudas a ser plantada. Já o uso de mão-de-obra contratada especificamente para este serviço, que pode ser classificada como temporária, indica um produtor mais capitalizado e, possivelmente, uma propriedade de tamanho médio a grande, ou seja, o que no critério ora adotado significa aquelas com mais de 50 hectares de área total. 
Também procurou-se saber, do PÚBLICO 1, se participaram da escolha das espécies, se rejeitaram ou rejeitariam alguma espécie fornecida pela CESP, se alguma espécie lhes trouxe qualquer tipo de inconveniente como invasão de área agrícola ou intoxicação de animais, se entenderam o modelo de plantio proposto pela CESP, e se poderiam reproduzi-lo em outras áreas caso fosse necessário. Estas perguntas dariam uma idéia do grau de participação do produtor na elaboração do modelo de plantio mais adequado às suas necessidades, e se esta ação teve um caráter educativo e participativo, ou apenas de transferência de tecnologia.

Perguntou-se ao PÚBLICO 2 quais os motivos que levaram os proprietários a desistir do contrato de fomento, para identificar os principais pontos a serem revistos no Programa de fomento florestal da CESP, como por exemplo: alguns termos do contrato, a qualificação técnica do funcionário que faz a visita aos produtores, as espécies arbóreas, o modelo de plantio, etc. Perguntou-se também se depois de ter desistido do contrato de fomento com a CESP, o produtor voltou a procurá-la para fazer um outro contrato, ou se ele teria interesse em conversar novamente com a Companhia.

Quanto ao PÚBLICO 3, formado por propriedades não cadastradas no viveiro de Porto Primavera e, portanto, totalmente desconhecido até o momento, perguntou-se de início se já conheciam o Programa de fomento florestal da CESP. Também perguntou-se se sabiam que este Programa poderia fornecer gratuitamente o projeto de reflorestamento, assistência técnica, mudas e transporte das mudas, e se conheciam alguma propriedade fomentada pela CESP. Além disso perguntou-se se gostariam de receber maiores informações sobre o fomento florestal da CESP, e se teriam sugestões para melhorar a divulgação do mesmo. O propósito aqui era o de avaliar a divulgação do Programa, e o seu potencial. 
Para o PÚBLICO 3, perguntou-se também se já haviam feito algum tipo de reflorestamento em suas propriedades, para identificar possíveis iniciativas dos produtores.

Optou-se pela tabulação e análise dos dados em função do número de propriedades fomentadas, visto que se fosse feita em função dos contratos de fomento, os dados referentes à propriedade, como área da mesma, presença e tamanho de fragmento florestal, cobertura florestal das margens dos rios, etc., poderiam ser contabilizados repetidas vezes, pois afinal existiam propriedades com mais de um contrato que, inclusive, poderiam pertencer a grupos distintos (ex.: uma determinada propriedade poderia ter um contrato de fomento classificado como vigente, e um outro, mais antigo, classificado como desistente). Desta forma, uma mesma propriedade, ou um mesmo proprietário, poderia receber mais de uma carta, com formulários de pesquisa diferentes, mas nestes casos, cada item, repetido ou não, dos formulários foi contabilizado apenas uma vez. 


\section{RESULTADOS E DISCUSSÃO}

4.1 Definição do Universo de Estudo: levantamento do número total de contratos de fomento estabelecidos e definição da amostra a ser pesquisada

O primeiro resultado obtido, nesta pesquisa, veio do levantamento do total de contratos de fomento florestal realizados pela Unidade de Produção de Mudas da CESP de Porto Primavera, desde o primeiro contrato firmado, em 1988, até o último a ser assinado no final de mês de dezembro de 1997. Neste período de 10 anos foram cadastrados, nos arquivos daquela unidade, 536 contratos de fomento florestal.

Dos 536 contratos de fomento, há propriedades em 80 municípios, apresentados no Anexo G, sendo 64 no Estado de São Paulo, 11 no Paraná, 4 no Mato Grosso do Sul, e 1 em Minas Gerais. A maioria dos contratos de fomento são em áreas particulares de pessoa física, mas algumas áreas pertencem a empresas ou Prefeituras. É importante destacar que algumas propriedades podem ter mais de um contrato de cooperação com a CESP. O proprietário pode ter feito um segundo contrato após o término do primeiro e, como foi constatado, uma mesma propriedade pode possuir contratos em nome de pessoas diferentes.

Do total de contratos, foram levantados: 274 contratos vigentes, 119 vencidos, e 143 classificados como desistentes, segundo critério adotado pela equipe técnica de 
fomento do viveiro (ver capítulo 3, referente à metodologia da pesquisa). Assim, cerca de $50 \%$ dos contratos ainda estavam em período de vigência, indicando que muitas mudas ainda estavam para sair do viveiro e que o contato da Companhia com o produtor rural em muitos casos só estava começando.

Para se ter uma idéia do que isso representa em número de mudas, o total contratado referente aos 274 contratos vigentes soma 1.221.984 mudas, das quais até o momento foram retiradas cerca de $22 \%$, ou 272.649 mudas. Muitas destas mudas ainda estavam para ser retiradas, visto que o fomentado normalmente tem um prazo de quatro anos para isso. Já os 119 contratos vencidos somavam 1.787.865 mudas contratadas, das quais 631.828 (35,3\%) foram retiradas. Essa grande diferença entre o número de mudas contratadas e o de retiradas indica que deve estar havendo problemas nas etapas seguintes à assinatura do contrato de fomento, que seriam a produção de mudas, a expedição, e a assistência técnica, ou uma insatisfação do produtor rural com o Programa.

Alguns produtores fomentados comentaram a dificuldade em se buscar as mudas no viveiro, principalmente devido à distância, como pode ser visto no seguinte depoimento: “...Depois foi dificil pegar mudas e optei por pegar mudas aqui perto em Assis..." (Propriedade de 73 ha em Pedrinhas Paulista). Este problema não ocorreria se a CESP levasse a muda até a propriedade.

Quanto aos 143 contratos desistentes, as mudas contratadas somavam 1.598.790 unidades. Isso representa cerca de metade das mudas contratadas nos contratos assinados em 10 anos, somando-se os vigentes e vencidos, que totalizaram 3.009.849 mudas. (ver item 4.5.10).

O fomento florestal do viveiro da CESP de Porto Primavera foi direcionado para as seguintes Usinas Hidroelétricas: UHE Esccla Mackenzie, UHE Escola Politécnica, 
UHE Porto Primavera, UHE Canoas I, UHE Canoas II, UHE Rosana, UHE Jurumirim, UHE Chavantes, e UHE Lucas Nogueira Garcez. No período de 1988 a 1994, os contratos de fomento do viveiro estavam mais concentrados nas áreas dos reservatórios da UHE Escola Mackenzie e a UHE Escola Politécnica. Nos anos de 1996 e 1997, os contratos de fomento estavam voltados para a UHE Canoas I e Canoas II.

Neste trabalho, optou-se desde o início por considerar apenas os contratos de fomento florestal de propriedades localizadas no Estado de São Paulo, em um total de 509 contratos, em 64 municípios. Porém, ainda se tratava de um número muito grande de contratos e de propriedades muito dispersas, dificultando o contato com os fomentados.

TABELA 1: $\mathrm{N}^{\circ}$ de contratos de fomento florestal organizados por Escritório de Desenvolvimento Rural da CATI/SAA-SP.

\begin{tabular}{|c|c|c|c|}
\hline EDR & \begin{tabular}{|l|} 
N. ${ }^{\circ}$ de municípios do \\
EDR com propriedades \\
fomentadas pela CESP
\end{tabular} & $\begin{array}{c}.^{\circ} \text { de contratos de } \\
\text { fomento florestal no } \\
\text { EDR }\end{array}$ & $\begin{array}{c}\% \text { do } \mathrm{N}^{0} \text { total de } \\
\text { contratos }\end{array}$ \\
\hline Assis & 12 & 305 & 56,90 \\
\hline Pres. Prudente & 15 & 84 & 15,67 \\
\hline Pres. Venceslau & 10 & 57 & 10,63 \\
\hline Tupã & 7 & 21 & 3,92 \\
\hline Ourinhos & 7 & 18 & 3,36 \\
\hline Dracena & 6 & 14 & 2,61 \\
\hline Avaré & 3 & 6 & 1,12 \\
\hline Marilia & 2 & 2 & 0,37 \\
\hline Araçatuba & 1 & 1 & 0,19 \\
\hline Botucatu & 1 & 1 & 0,19 \\
\hline Outros Estados & 16 & 27 & 5,04 \\
\hline Total & 80 & 536 & 100,00 \\
\hline
\end{tabular}

FONTE: Dados da Pesquisa

Como mostra a tabela do Anexo $G$, apenas 9 municípios continham mais que 10 contratos de fomento florestal, sendo eles: Cândido Mota (108), Palmital (76), Florínea (47), Assis (45), Teodoro Sampaio (20), Presidente Prudente (18), Marabá Paulista (14), Maracaí (12), e Tarabaí (12). Destes, os quatro primeiros pertencem à Regional CATI de 
Assis (EDR de Assis), que por sua vez concentra mais da metade do total contratos de fomento florestal (305 contratos, ou 56,90\% do total), como disposto na TABELA 1 .

Assim, decidiu-se concentrar este estudo nos 12 municípios do EDR de Assis, visto que são uma amostra significativa do fomento daquele viveiro da CESP (305 contratos), estão relativamente próximos uns dos outros, e as diferenças socioeconômicas entre eles não são tão grandes quando comparadas às dos 64 municípios do Estado, atendidos pelo Programa, que juntos somam 509 contratos.

A TABELA 2 relaciona os municípios do EDR de Assis e o número de contratos de fomento florestal classificados por situação em que se encontra o contrato, segundo a classificação apresentada anteriormente (vigentes, vencidos e desistentes). Como ilustra a tabela, os municípios de Cândido Mota, Palmital, Florínea e Assis concentram 90,49\% dos contratos de fomento florestal do EDR de Assis (276 dos 305 contratos), e representam $51,49 \%$ do total de contratos de fomento do viveiro de Porto Primavera (276 dos 536 contratos).

Ainda através da análise da TABELA 2, nota-se que, dos quatro municípios de maior participação no fomento florestal do viveiro da CESP de Porto Primavera, dois, Cândido Mota e Florínea, já ocupavam posição de destaque no Programa de Fomento do viveiro de Porto Primavera há algum tempo, possuindo grande número de contratos classificados como vencidos. Contratos de fomento classificados como desistentes são, na maioria, anteriores ao ano de 1993. A maioria dos contratos de fomento classificados como desistentes foram cadastrados nos anos de 1991 e 1992, principalmente nas áreas de influência das Usinas Hidroelétricas Escola Mackenzie e Canoas I. Sobre os motivos que podem levar à desistência do contrato por parte dos proprietários, temos o seguinte depoimento de um dos Técnicos de Meio Ambiente do Programa de Fomento Florestal da CESP: 
"Um fomentado de Assis desistiu do fomento quando ia assinar o contrato, porque a esposa não deixou ele assinar. A mulher ficou com receio do valor do contrato. Este valor é referente ao preço das mudas, mas é só uma referência, pois o fomentado não tem nenhum custo".

TABELA 2: N. ${ }^{\circ}$ Contratos de fomento organizados por município do EDR de Assis, e classificados em contratos vigentes, vencidos e desistentes.

\begin{tabular}{|l|r|r|r|r|}
\hline \multicolumn{1}{|c|}{ Município } & \multicolumn{1}{c|}{ Vigentes } & \multicolumn{1}{c|}{ Vencidos } & Desistentes & TOTAL \\
\hline Cândido Mota & 47 & 19 & 42 & 108 \\
Palmital & 69 & 1 & 6 & 76 \\
Florínea & 7 & 25 & 15 & 47 \\
Assis & 38 & 3 & 4 & 45 \\
Maracaí & 3 & 8 & 0 & 11 \\
Tarumã & 5 & 1 & 0 & 6 \\
Campos Novos Paulista & 0 & 0 & 5 & 5 \\
Paraguaçu Paulista & 1 & 0 & 1 & 2 \\
Pedrinhas Paulista & 0 & 1 & 1 & 2 \\
Cruzália & 0 & 1 & 0 & 1 \\
Ibirarema & 0 & 0 & 1 & 1 \\
Platina & 0 & 0 & 1 & 1 \\
\multicolumn{1}{r|}{ TOTAL } & $\mathbf{1 7 0}$ & $\mathbf{5 9}$ & $\mathbf{7 6}$ & $\mathbf{3 0 5}$ \\
\hline
\end{tabular}

FONTE: Dados da Pesquisa

Analisando-se detalhadamente a TABELA 2, observa-se que o município de Palmital, nos últimos anos, vem ocupando posição de destaque no fomento florestal do viveiro da CESP de Porto Primavera, pois a grande maioria dos contratos lá assinados ainda estão em vigor. Mais adiante, no capítulo 4.3, este assunto será melhor discutido.

Muitos contratos de fomento não registravam o endereço para correspondência do proprietário, ou o mesmo estava incompleto, nem tampouco o número do telefone para contato. Em consultas realizadas junto às Casas da Agricultura dos municípios, constatou-se que algumas propriedades realmente não possuíam endereço para 
correspondência na cidade, e por isso haviam fornecido apenas o nome do sítio e o município. Assim, a comunicação com esta parcela de proprietários tornou-se inviável.

Do total de 305 contratos, excluiu-se aqueles que estavam em nome de órgãos públicos, como prefeituras e escolas, e os que não continham endereço para correspondência, o que reduziu o universo de trabalho para 280 contratos de fomento florestal, como mostra a TABELA 3. Assim como fez a CESP, para facilitar a organização dos contratos, os mesmos foram separados em três grupos: contratos vigentes, vencidos e desistentes.

TABELA 3: N. $^{\circ}$ Cartas e formulários de pesquisa enviados por município do EDR de Assis, agrupados em contratos vigentes, vencidos e desistentes.

\begin{tabular}{|l|r|r|r|r|}
\hline \multicolumn{1}{|c|}{ Município } & Vigen tes & Vencidos & Desistentes & TOTAL \\
\hline Cândido Mota & 48 & 17 & 40 & 105 \\
Palmital & 66 & 0 & 6 & 72 \\
Florínea & 1 & 19 & 15 & 35 \\
Assis & 36 & 3 & 4 & 43 \\
Maracaí & 4 & 5 & 1 & 10 \\
Tarumã & 3 & 0 & 4 \\
Campos Novos Paulista & 0 & 1 & 0 & 5 \\
Paraguaçu Paulista & 1 & 0 & 1 & 5 \\
Pedrinhas Paulista & 0 & 1 & 1 & 2 \\
Cruzália & 0 & 1 & 0 & 2 \\
Ibirarema & 0 & 0 & 1 & 1 \\
Platina & 0 & 0 & 0 & 1 \\
\multicolumn{1}{|c|}{ TOTAL } & 159 & 47 & $\mathbf{7 4}$ & $\mathbf{2 8 0}$ \\
\hline
\end{tabular}

FONTE: Dados da Pesquisa

Como se pode observar ao analisar TABELA 2, o PÚBLICO 1 era composto de 229 contratos de fomento (170 vigentes e 59 vencidos), e o PÚBLICO 2 de 76 contratos de fomento (76 desistentes), totalizando 305 contratos. Porém, a TABELA 3 mostra que 
foram enviadas 206 cartas para o PÚBLICO 1 (159 vigentes e 47 vencidos) e 74 cartas para o PÚBLICO 2 (74 desistentes), num total de 280 cartas.

Quanto ao PÚBLICO 3 (propriedades não cadastradas no programa de fomento da CESP), decidiu-se enviar cartas para 100 produtores da região tomados ao acaso. Posteriormente, por problemas operacionais, optou-se por distribuir estas cartas, com a ajuda da CATI, para propriedades nos municípios de Cândido Mota, Palmital, Assis e Platina, visto que, segundo os Engenheiros Agrônomos da Casa da Agricultura de Palmital, eram estes os municípios mais próximos da área que está sendo priorizada atualmente pelo Programa de fomento Florestal da CESP na região. Foram destinadas 25 cartas para cada município.

Desta forma, foram enviadas 380 cartas contendo formulários de pesquisa, sendo 206 para o PÚBLICO 1, 74 para o PÚBLICO 2 e 100 para o PÚBLICO 3. A expectativa era a de receber algo em torno de $10 \%$ de resposta, o que já seria uma amostragem suficiente para a análise que desejava-se realizar.

\subsection{Estrutura Fundiária da Região Estudada}

A Secretaria da Agricultura e Abastecimento do Estado de São Paulo (S.A.A.), através da Coordenadoria de Assistência Técnica Integral (CATI), desenvolveu o Levantamento Censitário das Unidades de Produção Agropecuária (LUPA), cadastrando 277.124 propriedades agrícolas nos 641 municípios do Estado de São Paulo, abrangendo uma área de cerca de 20 milhões de hectares. Em cada propriedade foram identificados os tipos de culturas, a área ocupada por cada atividade, criações, benfeitorias, máquinas e equipamentos, número de trabalhadores, grau de instrução do proprietário, infraestrutura, etc. A consulta ao banco de dados do Projeto LUPA é solicitada pelo 
interessado e executada pela equipe do Núcleo de Agronegócios/CATI, a um custo de R\$ 0,10 (dez centavos) por cada cruzamento de dados, sendo que o valor do pedido mínimo será equivalente a 20 cruzamentos. Em nenhuma hipótese serão fornecidos os dados cadastrais ao interessado (Secretaria da Agricultura e Abastecimento de São Paulo, 1997).

As Unidades de Produção Agropecuária do Estado de São Paulo foram estratificadas em classes de tamanho de área pelo Projeto LUPA, como mostra a TABELA 4. Neste trabalho, utilizou-se o mesmo critério de estratificação para facilitar o cruzamento dos dados coletados com os do Projeto LUPA. Segundo estas informações, no Estado de São Paulo há o predomínio de propriedades com área variando de 2,5 a 100 hectares, ou seja, propriedades que podem ser classificadas como pequenas e médias.

TABELA 4: Estratificação das Propriedades Agropecuárias do Estado de São Paulo em classes de tamanho.

\begin{tabular}{|l|r|r|}
\hline $\begin{array}{c}\text { Classe de tamanho das } \\
\text { UPAs (ha) no Estado }\end{array}$ & Número de UPAs & \multicolumn{2}{|c|}{$\begin{array}{c}\text { Participação da classe no } \\
\text { total de UPAs(\%) }\end{array}$} \\
\hline$(0,1]$ ha & 3.765 & 1,359 \\
$(1,2]$ ha & 6.018 & 2,172 \\
$(2,5]$ ha & 30.035 & 10,838 \\
$(5,10]$ ha & 37.340 & 13,474 \\
$(10,20]$ ha & 58.778 & 21,210 \\
$(20,50]$ ha & 71.070 & 25,646 \\
$(50,100]$ ha & 31.385 & 11,325 \\
$(100,200]$ ha & 19.151 & 6,911 \\
$(200,500]$ ha & 13.277 & 4,791 \\
$(500,1.000]$ ha & 4.055 & 1,463 \\
$(1.000,2.000]$ ha & 1.602 & 0,578 \\
$(2.000,5.000]$ ha & 552 & 0,199 \\
$(5.000,10.000]$ ha & 68 & 0,025 \\
P10.000 ha & 277.124 & 0,010 \\
TOTAL & $\mathbf{2 7 0 0}$ \\
\hline
\end{tabular}

FONTE: Secretaria da Agricultura e Abastecimento de São Paulo, Projeto LUPA (Informações Econômicas, SP, v. 27, n. 11, nov. 1997). 
A TABELA 5, apresenta os dados referentes à região do Escritório de Desenvolvimento Rural da CATI de Assis, fornecidos pela mesma fonte, que corresponde à área estudada.

TABELA 5: Estratificação das Propriedades Agropecuárias do Escritório de Desenvolvimento Rural da CATI de Assis. em classes de tamanho.

\begin{tabular}{|lr|r|r|}
\hline $\begin{array}{l}\text { Classe de tamanho das } \\
\text { UPAs (ha) no EDR de }\end{array}$ & Número de UPAs & $\begin{array}{l}\text { Participação da classe no } \\
\text { total de UPAs(\%) }\end{array}$ \\
Assis & & 39 & 0,482 \\
$(0,1]$ ha & 73 & 0,902 \\
$(1,2]$ ha & 537 & 6,637 \\
$(2,5]$ ha & 883 & 10,913 \\
$(5,10]$ ha & 1.703 & 21,048 \\
$(10,20]$ ha & 2.406 & 29,737 \\
$(20,50]$ ha & 1.091 & 13,484 \\
$(50,100]$ ha & 661 & 8,170 \\
$(100,200]$ ha & 533 & 6,588 \\
$(200,500]$ ha & 111 & 1,372 \\
$(500,1.000]$ ha & 37 & 0,457 \\
$(1.000,2.000]$ ha & 14 & 0,173 \\
$(2.000,5.000]$ ha & 3 & 0,037 \\
$(5.000,10.000]$ ha & 0 & 0,000 \\
$>10.000$ ha & $\mathbf{8 . 0 9 1}$ & $\mathbf{1 0 0 , 0 0 0}$ \\
\hline
\end{tabular}

FONTE: Secretaria da Agricultura e Abastecimento de São Paulo, Projeto LUPA (Informações Econômicas, SP. v. 27, n. 11, p.27, nov. 1997).

A análise das TABELAS 4 e 5 mostra que a estrutura fundiária da região de Assis tem a mesma tendência (estatística) da média do Estado de São Paulo, predominando propriedades de até 50 hectares de área o que também pode ser visto pelo gráfico da FIGURA 1. Deste modo, espera-se que uma amostra da região de Assis forneça uma imagem próxima do que se tem em todo o Estado. 


\section{FIGURA 1: Gráfico da estrutura fundiária do Estado de São}

\section{Paulo e da região de Assis}

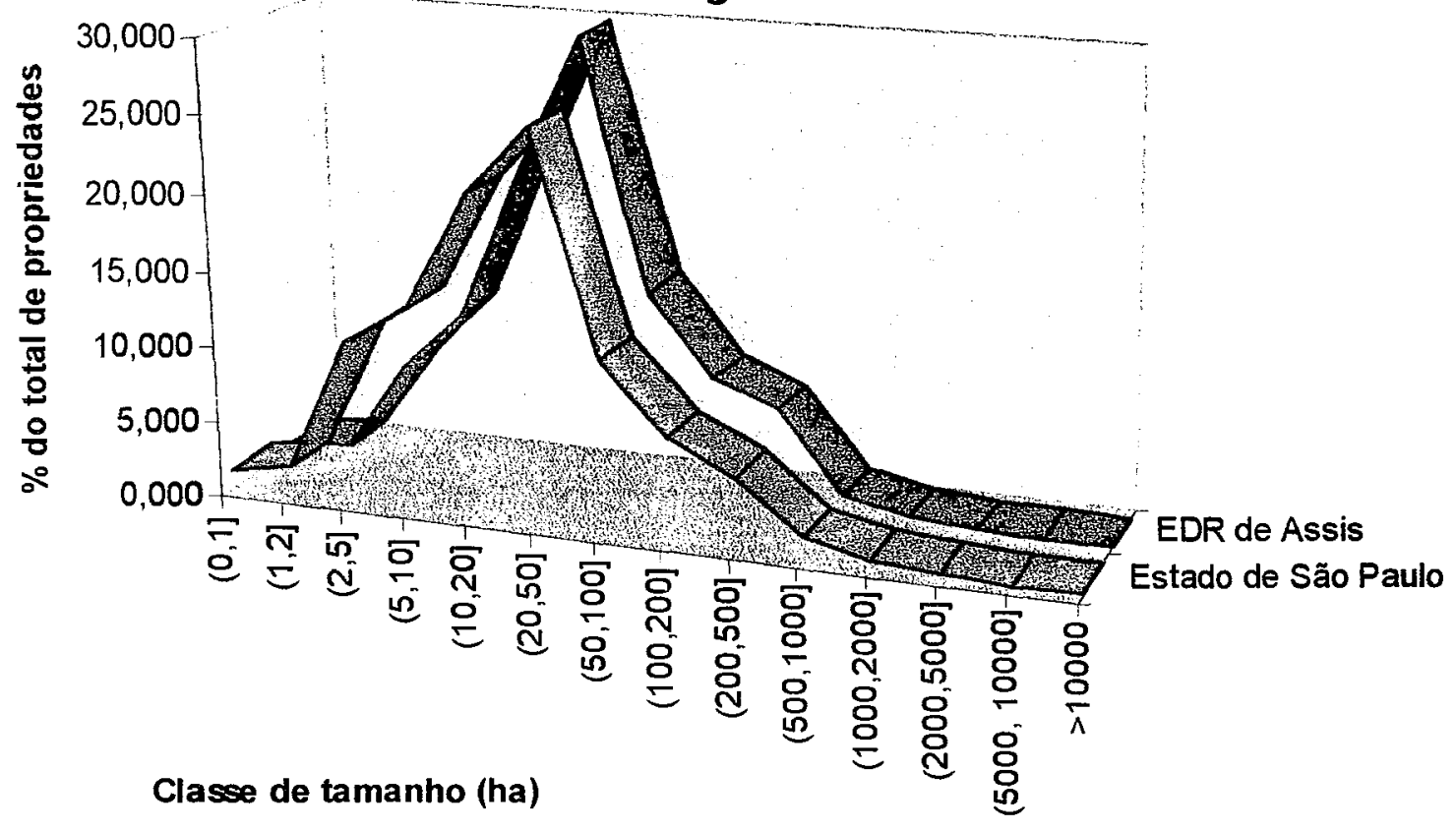

FONTE: Secretaria da Agricultura e Abastecimento de São Paulo, Projeto LUPA (Informações Econômicas, SP, v. 27, n. 11. p.27, nov. 1997).

\subsection{O fomento florestal da CESP no município de Palmital}

Como demonstra a TABELA 6, o número de solicitações de produtores rurais para participação no Programa de Fomento Florestal da CESP tem oscilado bastante de ano para ano, não havendo uma tendência clara de crescimento ou redução.

Silva (1992), ao estudar a evolução da área plantada pelo Programa de Recomposição de Matas Nativas empreendidos pela CESP, no final de década de 1980, observou também uma oscilação grande na área plantada. como mostra a TABELA 7. 
Segundo o autor, a evolução do programa e de suas concepções norteadoras não se deu de forma contínua e homogênea, e esteve relacionada com um contexto histórico, mudando também a importância dada à questão ambiental.

TABELA 6: N. ${ }^{\circ}$ Solicitações de produtores rurais para participar do fomento florestal da CESP, listadas por ano, e situação dos contratos de fomento em dezembro de 1997.

\begin{tabular}{|c|c|c|c|c|}
\hline \multirow[t]{2}{*}{$\begin{array}{l}\text { Ano da Solicitação de } \\
\text { Fomen to Florestal }\end{array}$} & \multirow[t]{2}{*}{$\begin{array}{l}\mathrm{N} .^{\circ} \text { de Solicitações de } \\
\text { Fomento florestal }\end{array}$} & \multicolumn{3}{|c|}{$\begin{array}{l}\text { Situação em que se encontravam } \\
\text { os Contratos de Fomento } \\
\text { Florestal em Dezembro de } 1997\end{array}$} \\
\hline & & Vigentes & Vencidos & Desistentes \\
\hline 1988 & 3 & 0 & 1 & 2 \\
\hline 1989 & 47 & 0 & 42 & 5 \\
\hline 1990 & 28 & 0 & 20 & 8 \\
\hline 1991 & 78 & 0 & 34 & 44 \\
\hline 1992 & 64 & 3 & 11 & 50 \\
\hline 1993 & 34 & 13 & 11 & 10 \\
\hline 1994 & 30 & 18 & 0 & 12 \\
\hline 1995 & 34 & 26 & 0 & 8 \\
\hline 1996 & 50 & 48 & 0 & 2 \\
\hline 1997 & 168 & 166 & 0 & 2 \\
\hline TOTAL & 536 & 274 & 119 & 143 \\
\hline
\end{tabular}

FONTE: Dados da Pesquisa

TABELA 7: Evolução da área plantada, em hectares, pelo Programa de Recomposição de Matas Nativas da CESP.

\begin{tabular}{cccccccccccc}
\hline Anos & 79 & 80 & 81 & 82 & 83 & 84 & 85 & 86 & 87 & 88 & Total \\
$\begin{array}{c}\text { Áreas } \\
\text { (ha) }\end{array}$ & 460 & 160 & 50 & 50 & 128 & 637 & 557 & 603 & 183 & 63 & 2891 \\
\hline
\end{tabular}

FONTE: Silva (1992)

Se o Programa de Recomposição de Matas Nativas da CESP em todo o Estado não consegue se manter estável, já era de se esperar o mesmo para o Programa de Fomento Florestal da empresa. que é apenas mais um dos seus componentes. 
Das 168 solicitações de contrato de fomento florestal registradas em 1997, como mostra a TABELA 6, $48(28,57 \%)$ foram do município de Palmital, 46 (27,38\%) de Cândido Mota, $38(22,62 \%)$ de Assis, e os outros $36(21,43 \%)$ de outros municípios. Palmital também foi o município que mais fez solicitações no ano de 1996, com 21 (42\%) do total de 50 solicitações.

A expressiva participação do município de Palmital no Programa de Fomento Florestal do viveiro da CESP de Porto Primavera nos dois últimos anos, 1996 e 1997, levou ao aprofundamento do estudo naquela direção, e à investigação das razões que teriam contribuido para isso. As perguntas a serem respondidas eram: porque os produtores rurais de Palmital têm feito tantas solicitações de contrato de fomento florestal com a CESP? Qual a diferença entre Palmital e os outros municípios da região?

A própria equipe técnica de fomento florestal do viveiro da CESP de Porto Primavera comentou que a grande participação de Palmital, no Programa nos anos de 1996 e 1997, se devia à atuação do promotor público que estava pressionando os produtores rurais do município a plantar florestas. Posteriormente esta informação foi confirmada pela Casa da Agricultura de Palmital, que acrescentou também uma série de outros motivos.

Em setembro de 1998, ao enviar os formulários de pesquisa aos produtores fomentados pela CESP, foi realizada uma visita à Casa da Agricultura de Palmital. Nesta oportunidade, contatou-se os dois Engenheiros Agrônomos que acompanharam o fomento da CESP no município. um no ano de 1996 e o outro em 1997. Ambos foram bastante receptivos, passaram várias informações interessantes sobre o fomento florestal no município, além de permitir a consulta aos arquivos da Casa da Agricultura.

No final da década de 80, o Programa Estadual de Micro Bacias, da CATI/SAASP, selecionou a Micro Bacia Água das Anhumas (2.800 ha de área e 54 produtores), 
localizada no município de Palmital, como uma das áreas a serem trabalhadas, desencadeando uma série de ações, com as primeiras reuniões com produtores, a partir de 1989.

No período de 1991 a 1993 foram feitos os trabalhos de conservação de solo e hora máquina, eliminando problemas causados pela erosão, realocação e manutenção de estradas, etc. Com o término das ações daquela etapa do Programa de Micro Bacias, a partir de 1996 foram feitos plantios de matas ciliares executados pela Casa da Agricultura de Palmital, em parceria com a Prefeitura (viveiro de espera, transporte das mudas, Agrônomo e mão-de-obra); CESP (mudas); APABEM (Associação para o Bem Estar dos Menores Carentes, que cedeu a mão-de-obra das crianças para parte dos plantios em atividades de educação ambiental); Promotoria de Justiça (exigindo o plantio das matas ciliares); como também o Horto Florestal de Assis e a associação de reposição florestal Flora Vale (consultadas informalmente por telefone para alguns esclarecimentos). Estas informações foram fornecidas pelo Eng. Agrônomo da Prefeitura de Palmital.

Segundo o Eng. Agrônomo da Prefeitura de Palmital (comunicação pessoal), $a$ Promotoria de Justiça pressionou todos os produtores da MBH a reflorestarem as margens dos corpos d'água (rios e lagos) e nascentes, e se não fosse assim, a resistência de alguns produtores teria sido muito grande. Todos os trabalhos de contato direto com o produtor, assistência técnica, etc., foram feitos por funcionários da Prefeitura Municipal e da Casa da Agricultura de Palmital. Estes técnicos receberam orientações da CESP sobre o modelo de plantio, mas nada oficial e por escrito. Esta atitude da CESP poderia acarretar problemas de ordem técnica, visto que a equipe da empresa tem sido exaustivamente treinada para a tarefa, o que não se pode garantir de técnicos de outras instituições.

A seguinte reportagem, retirada de uma edição do Informativo Agrícola Coopermota, publicado em 1996, revela a estratégia utilizada para a adesão dos 
proprietários: "A partir da safra de inverno/96 os produtores da Microbacia da Anhumas,... em Palmital, não poderão mais plantar em a, pelo menos, 15 metros da margem do rio e, na próxima safra, a 30 metros da margem. Essa decisão foi tomada em conjunto com os próprios produtores daquela região no final do ano passado, numa reunião da qual participou a maioria dos produtores desta micro bacia e, inclusive, com a presença da Curadora do Meio Ambiente. Cristiane Patrícia Cabrine, de Palmital. De acordo com a legislação, o produtor não pode utilizar essa área próxima ao rio para cultivo (soja, milho, trigo, arroz, pastagem. etc.). A recomendação é para formar mata ciliar com a utilização de espécies próprias. que serão fornecidas gratuitamente pela Casa da Agricultura de Palmital, através da Flora Vale e CESP. Segundo a Curadora do Meio Ambiente, o produtor poderá sofrer uma ação civil pública, com medida liminar judicial, obrigando-o ao pagamento de uma multa diária até o cumprimento do que ficou estabelecido. ...".

Certamente o envolvimento dos produtores, iniciado em 1989 com o advento do Programa de Micro Bacias, e a participação deles na definição de um cronograma de ações visando a adequação das propriedades à legislação ambiental, além da participação do Estado, e organizações da sociedade civil, foram responsáveis pela adesão dos proprietários nas ações de recuperação das matas ciliares da micro bacia. A adesão dos proprietários de terras da Micro Bacia de Anhumas, em Palmital, ao programa de recuperação da mata ciliar parece ter sido muito mais pela confiança passada pelas instituições públicas comprometidas com eles na busca de uma melhoria na qualidade de vida naquele local, do que simplesmente uma obrigação legal.

Coincidentemente um dos 6 produtores de Palmital que desistiram do fomento da CESP era a esposa de um dos Eng. Agrônomos da Casa da Agricultura. Ele relatou que muitos produtores relacionados como desistentes, na verdade gostariam de ter recebido e plantado as mudas, mas não o fizeram porque a CESP acabou não transportando as mudas para propriedades isoladas. A empresa só enviava as mudas quando completava 
um caminhão, o que nunca acontecia em algumas regiões devido ao pequeno número de mudas solicitado. Desta forma o produtor só tinha duas opções, que seria buscar as mudas na CESP e, neste caso, arcar com o custo do transporte, ou desistir do fomento.

Para solucionar este problema, a Prefeitura de Palmital cedeu uma área para servir de viveiro de espera. Assim, a CESP levava as mudas de todos os produtores fomentados no município para este local, e a Prefeitura tratava de distribuí-las segundo orientações da CESP, que determinava, previamente, as espécies e a quantidade de mudas de cada uma delas que deveria seguir para cada produtor. Esta foi, sem sombra de dúvidas, uma alternativa muito oportuna e eficiente, possibilitando a participação de todos no programa, desde aqueles que plantariam áreas muito pequenas (poucas centenas de mudas), até os que plantariam alguns hectares (alguns milhares de mudas).

Foram visitados alguns plantios com mudas da CESP na Microbacia Hidrográfica de Anhumas, que em geral estavam em boas condições. Alguns produtores cuidaram mais do que outros, principalmente na manutenção do plantio. Os plantios mais antigos estavam com cerca de três anos na data da visita (setembro de 1998) e, em vários deles, foi possível detectar o início da produção de sementes das espécies pioneiras, formando o banco de sementes naquela área. $\mathrm{O}$ recobrimento do solo proporcionado pelas espécies pioneiras plantadas, possibilitou o estabelecimento de espécies secundárias e clímax cujas sementes vieram de fragmentos ou árvores adultas próximas às áreas de plantio, com destaque para o cedro-rosa (Cedrela fissilis Vell.).

Por outro lado, observou-se que alguns produtores não seguiram as recomendações de plantio feitas pela CESP e Casa da Agricultura. Em áreas onde deveriam ter sido plantadas linhas alternadas de espécies pioneiras com linhas de espécies não pioneiras, foram feitos plantios ao acaso. Em outras áreas, as pioneiras foram plantadas separadamente das não pioneiras. Tais problemas poderiam ter sido 
solucionados com o acompanhamento dos plantios por técnicos da CESP ou da Casa da Agricultura, o que nem sempre foi possivel.

Em algumas áreas a diversidade de espécies plantadas era pequena, com menos de 20 espécies. Em vários plantios comprovou-se a baixíssima diversidade de espécies pioneiras, com uma ou duas espécies por plantio, muitas vezes sendo uma espécie para áreas mais secas e outra para áreas mais úmidas. Este pode ter sido um problema operacional da CESP, que poderia ter sido solucionado com um melhor planejamento do viveiro. Porém, esta observação de campo não condiz com o conteúdo apresentado nas TABELAS 8 e 9. Uma das explicações possíveis é que houve mortalidade de mudas no viveiro de espera ou no campo, e as mudas não foram substituídas de acordo com a orientação inicial da CESP. Por outro lado, pode ser que o problema tenha sido no transporte das mudas do viveiro de espera da Prefeitura para as propriedades, não tendo sido seguidas as recomendações da CESP.

Na visita ao viveiro de espera da Prefeitura de Palmital, foi possível perceber que as mudas que não foram repassadas imediatamente para os produtores; elas foram transferidas das embalagens originais, que eram tubetes com $50 \mathrm{~cm}^{3}$ de substrato, para saquinhos plásticos maiores. O Eng. Agrônomo da Prefeitura relatou, e depois mostrou na prática, que a CESP sempre manda uma muda de cada espécie identificada com uma etiqueta, para que as demais sejam identificadas e encanteiradas por espécie. Porém, em alguns casos as etiquetas se perderam com o tempo, e o pessoal do viveiro estava com uma certa dificuldade na identificação de algumas espécies.

Na Casa da Agricultura de Palmital obteve-se cópias das listagens de espécies enviadas pela CESP para a maioria dos produtores da MBH de Anhumas, no ano de 1996, totalizando 20 propriedades e cerca de 15.000 mudas, o que permite uma análise da diversidade de espécies do programa de fomento da CESP naquele ano (TABELA 8). Também foram fornecidas 11 listas de espécies com cerca de 21.000 mudas pạra projetos 
de fomento implantados no ano de 1997, em Palmital (TABELA 9). É importante destacar que nem a própria CESP arquivou estes dados, e que guardá-los foi uma iniciativa do então Eng. Agrônomo da Casa da Agricultura, hoje trabalhando na Prefeitura do município.

TABELA 8: Número de mudas e de espécies fornecidas aos fomentados da CESP em Palmital no ano de 1996.

\begin{tabular}{|r|r|r|r|r|}
\hline Projeto de & Total & \multicolumn{3}{|c|}{ Número de Espécies } \\
& de & & \multicolumn{3}{|c|}{} \\
\cline { 3 - 5 } Fomento & Mudas & Pioneiras & Não Pioneiras & Total \\
\hline 01 & 1400 & 07 & 20 & 27 \\
02 & 300 & 05 & 11 & 16 \\
03 & 750 & 05 & 14 & 19 \\
04 & 650 & 06 & 15 & 21 \\
05 & 120 & 05 & 06 & 11 \\
06 & 1300 & 05 & 18 & 23 \\
07 & 700 & 06 & 14 & 20 \\
08 & 550 & 06 & 16 & 22 \\
09 & 380 & 07 & 14 & 21 \\
10 & 1880 & 07 & 16 & 23 \\
11 & 870 & 07 & 11 & 18 \\
12 & 1000 & 07 & 13 & 20 \\
13 & 380 & 06 & 13 & 19 \\
14 & 700 & 07 & 14 & 20 \\
15 & 550 & 07 & 14 & 20 \\
17 & 950 & 07 & 13 & 19 \\
18 & 1150 & 07 & 14 & 20 \\
19 & 1500 & 06 & 14 & 20 \\
20 & 120 & 06 & 11 & 17 \\
21 & 170 & 06 & 13 & 19 \\
\hline
\end{tabular}

FONTE: Listas fornecidas pela CESP, arquivadas na Casa da Agricultura de Palmital. 
TABELA 9: Número de mudas e de espécies fornecidas aos fomentados da CESP em Palmital no ano de 1997.

\begin{tabular}{|r|r|r|r|r|}
\hline Projeto de & \multicolumn{1}{|c|}{$\begin{array}{c}\text { Total } \\
\text { de }\end{array}$} & \multicolumn{3}{|c|}{ Número de Espécies } \\
\cline { 3 - 5 } Fomento & Mudas & Pioneiras & Não Pioneiras & Total \\
\hline 01 & 270 & 06 & 19 & 27 \\
02 & 570 & 06 & 19 & 27 \\
03 & 500 & 07 & 22 & 29 \\
04 & 1300 & 07 & 21 & 28 \\
05 & 4800 & 05 & 21 & 26 \\
06 & 980 & 06 & 20 & 26 \\
07 & 570 & 06 & 21 & 27 \\
08 & 1200 & 07 & 21 & 28 \\
09 & 650 & 07 & 21 & 28 \\
10 & 300 & 07 & 21 & 28 \\
11 & 3250 & 06 & 21 & 27 \\
\hline
\end{tabular}

FONTE: Listas fornecidas pela CESP, arquivadas na Casa da Agricultura de Palmital.

Segundo informações fornecidas pela equipe técnica do viveiro de Porto Primavera, são enviadas mudas de 20 a 50 espécies diferentes para cada propriedade fomentada, dependendo da época do ano e do número de mudas requisitado. $\mathrm{O}$ viveiro de Porto Primavera produz anualmente mais de um milhão de mudas de 80 espécies nativas', sendo que durante todo o ano conta com uma média de 50 espécies disponíveis.

Pelas listagens de espécies enviadas pela CESP ao viveiro de espera de Palmital para serem entregue posteriormente aos responsáveis pelos 31 contratos de fomento florestal, cujo resumo foi apresentado nas TABELAS 8 e 9, nota-se que apenas 4 possuem menos de 19 espécies diferentes de árvores nativas. Destas, somente o projeto de fomento número 5, de 1996, com 11 espécies, apresenta uma quantidade de espécies bem abaixo do número mínimo indicado pelo próprio viveiro de produção de mudas da empresa em Porto Primavera. que é de 20 espécies. Mesmo assim, trata-se de um dos

\footnotetext{
1 Levantamentos fitossociológicos realizados na região encontraram 111 espécies arbóreas, como informou a equipe técnica do viveiro de produção de mudas da CESP de Porto Primavera.
} 
dois menores contratos, ambos com apenas 120 mudas, o que ameniza bastante o problema.

O número de espécies pioneiras, entendidos aqui como espécies pioneiras e secundárias iniciais da classificação de Budowski (1965), variou entre 5 e 7 nas 31 listagens. Este padrão é adequado, visto que na natureza são poucas as espécies que cumprem a função de colonizar as grandes clareiras e preparar o ambiente, através do sombreamento do solo, preparando-o para a chegada das espécies mais tolerantes à sombra.

$\mathrm{Na}$ floresta tropical. a diversidade é proporcionada pelas espécies não pioneiras, que nada mais são do que as classificadas por Budowski (1965) como secundárias tardias e clímax. Observa-se, pelos dados das TABELAS 8 e 9, que a CESP tem procurado seguir está linha também nos plantios realizados pelos seus fomentados. Isso fica mais evidente na TABELA 9, contratos de 1997, onde a diversidade das mudas enviadas para os contratos de fomento é maior do que do ano anterior (TABELAS 8). Em 1997, a quantidade de espécies de pioneiras continuou a mesma que a do ano anterior, mas a quantidade de espécies não pioneiras aumentou sensivelmente. $O$ fato sugere também que a CESP estaria se empenhando em aumentar a cada ano, na medida do possível, a diversidade e, conseqüentemente, a qualidade dos plantios em propriedades fomentadas.

Por sugestão do Professor Oriowaldo Queda (ESALQ/USP), foi possível ter acesso ao resultado de um levantamento socioeconômico relacionado ao reflorestamento, realizado na Micro Bacia Água das Anhumas, no município de Palmital, supostamente realizado pelo Instituto Florestal, e enviadas em janeiro de 1995 para o Diretor Executivo do CDVale (Centro de Desenvolvimento do Vale do Paranapanema). Segundo o levantamento, trata-se de produtores de nível econômico médio e médio-alto, que moram na cidade, com propriedades de 10 a 50 alqueires. com solo de terra roxa, e plantio 
agrícola de soja, milho e trigo. Eles não se interessam pelo reflorestamento comercial, mas são favoráveis ao reflorestamento para a conservação da natureza, com espécies frutíferas e nativas. A mata ciliar é quase inexistente. Apesar de conscientizados, os produtores apresentam muita resistência em reconstituí-la, temendo a diminuição das áreas de plantio. A quantidade de árvores nas propriedades é muito pequena.

O relatório do levantamento socioeconômico da Micro Bacia Água das Anhumas informa que o Programa de implantação de Micro Bacia, iniciado quatro anos antes (1991), trazendo várias melhorias para a região, quando foram feitas curvas de nível, as estradas foram levantadas, de forma que grande parte dos problemas da Micro Bacia foram resolvidos. Entretanto, continua o relatório, a única coisa que não foi possível ainda fazer, foi a reconstituição da mata ciliar, que está praticamente ausente. A resistência é grande, pois plantam até quase a beira do rio e não querem perder nenhum metro de área agrícola.

O levantamento da Micro Bacia aponta que os produtores consideram que $20 \%$ de área de reserva legal é um valor elevado e, assim. é difícil cumprir a lei. Defendem a idéia de que a quantidade deveria ser proporcional à área da propriedade (propriedade maior, reserva maior, e vice-versa). Mudas gratuitas animam alguns proprietários a realizar o plantio. Outros sentiriam-se incentivados caso a iniciativa de plantar árvores fosse em conjunto e somente na beira dos rios.

Iniciativas como as do município de Palmital deveriam ser incentivadas pela CESP, aumentando a área efetivamente plantada e a eficiência dos plantios. Porém, a empresa deveria ter uma participação mais efetiva no processo, garantindo a manutenção do padrão de qualidade do modelo de reflorestamento misto com espécies nativas desenvolvido pela empresa. 


\subsection{Caracterização das propriedades que responderam os formulários de pesquisa enviados pelo correio}

Como revela a $T A B E L A 10$, as respostas recebidas foram classificadas por contrato de fomento e por propriedade fomentada, visto que algumas propriedades que enviaram as respostas, possuíam mais de um contrato de fomento. Nestes casos os proprietários receberam mais de um formulário de pesquisa, porém só retornaram um deles respondido.

Mesmo tendo revisado os endereços para correspondência de todos os fomentados, 30 cartas foram devolvidas pelo correio, o que corresponde a $10,71 \%$ do total enviado. Obteve-se resposta de 56 contratos de fomento, 20,00\% do total, que representam 51 propriedades rurais diferentes, como demonstra a TABELA 10. Optou-se por analisar os dados obtidos através dos formulários respondidos por propriedade rural, ou Unidade de Produção Agropecuária (UPA), que é o objeto desse estudo.

Das cartas devolvidas, 20 devoluções foram justificadas pelo correio como NÃO PROCURADO/ZONA RURAL, sendo que deste total 17 eram do município de Cândido Mota e 3 de Florínea. Este tipo de problema dificulta ainda mais um trabalho como este. Além da dificuldade para se chegar até as propriedades rurais, devido à ausência de mapa (ou croqui) de localização e à grande distância entre elas, muitos dos proprietários não indicaram um endereço para correspondência na cidade, e o correio não chega às suas propriedades.

As 5 cartas do município de Palmital que foram devolvidas não apresentaram o motivo da devolução, assim como uma de Cândido Mota. As demais justificativas de devolução, todas com um caso registrado foram: mudou-se; desconhecido; o número indicado não existe; e endereço insuficiente. 
TABELA 10: $\mathrm{N} .^{\circ}$ de formulários de pesquisa enviados e respondidos, e cartas devolvidas pelo correio, listadas por município do EDR de Assis.

\begin{tabular}{|l|r|r|r|r|}
\hline \multicolumn{1}{|c|}{ Município } & $\begin{array}{c}\text { Formulários } \\
\text { enviados }\end{array}$ & $\begin{array}{c}\text { Formulários } \\
\text { respondidos por } \\
\text { contrato de } \\
\text { fomento }\end{array}$ & $\begin{array}{c}\text { Formulários } \\
\text { respondidos por } \\
\text { propriedade rural } \\
\text { (UPA) }\end{array}$ & $\begin{array}{c}\text { Cartas } \\
\text { devolvidas }\end{array}$ \\
\hline Cândido Mota & 105 & 16 & 16 & 19 \\
Palmital & 72 & 17 & 17 & 5 \\
Assis & 43 & 2 & 2 & 1 \\
Florínea & 35 & 9 & 7 & 3 \\
Maracaí & 10 & 3 & 1 & 0 \\
Campos Novos & 5 & 2 & 2 & 1 \\
Paulista & 4 & 4 & 3 & 0 \\
Tarumã & 3 & 1 & 1 & 0 \\
Pedrinhas Paulista & 2 & 2 & 2 & 0 \\
Paraguaçu Paulista & 1 & 0 & 0 & 1 \\
Cruzália & 280 & & $\mathbf{5 1}$ & $\mathbf{3 0}$ \\
\hline \multicolumn{1}{r|}{ TOTAL } & & & & \\
\hline
\end{tabular}

FONTE: Dados da Pesquisa

No momento em que se estava revisando os endereços dos fomentados, percebeuse que alguns deles eram comuns a várias propriedades, e posteriormente constatou-se que esses produtores haviam fornecido o endereço das Casas da Agricultura dos municípios mais próximos. Mais uma vez destacou-se a importância da Casa da Agricultura, e da CATI, para a comunidade rural do Estado de São Paulo, como também para qualquer tipo de trabalho de extensão rural, fomento e pesquisa agropecuária no Estado. 
TABELA 11: Estratificação das Unidades de Produção Agropecuárias do EDR de Assis e das Propriedades Amostradas em classes de tamanho.

\begin{tabular}{|c|c|c|c|c|}
\hline \multirow[t]{2}{*}{$\begin{array}{l}\text { Classe de tamanho } \\
\text { das UPAs (ha) }\end{array}$} & \multicolumn{2}{|c|}{ EDR de Assis ( $\left.{ }^{*}\right)$} & \multicolumn{2}{|c|}{$\begin{array}{l}\text { Propriedades Amostradas } \\
\text { (formulários respondidos) }\end{array}$} \\
\hline & $\begin{array}{c}\text { Número de } \\
\text { UPAs }\end{array}$ & $\begin{array}{l}\text { Participação da classe } \\
\text { no total de UPAs }(\%)\end{array}$ & $\begin{array}{c}\text { Número de } \\
\text { UPAs }\end{array}$ & $\begin{array}{l}\text { Participação da } \\
\text { classe no total de } \\
\text { UPAs(\%) }\end{array}$ \\
\hline$(0,1]$ ha & 39 & 0,482 & 0 & 0,000 \\
\hline$(1,2]$ ha & 73 & 0,902 & 0 & 0,000 \\
\hline$(2,5]$ ha & 537 & 6,637 & 1 & 1,961 \\
\hline$(5,10]$ ha & 883 & 10,913 & 4 & 7,843 \\
\hline$(10,20]$ ha & 1.703 & 21.048 & 14 & 27,451 \\
\hline$(20,50]$ ha & 2.406 & 29,737 & 11 & 21,569 \\
\hline$(50,100]$ ha & 1.091 & 13,484 & 7 & 13,725 \\
\hline$(100,200]$ ha & 661 & 8.170 & 5 & 9,804 \\
\hline$(200,500]$ ha & 533 & 6,588 & 3 & 5,882 \\
\hline$(500,1.000]$ ha & 111 & 1,372 & 1 & 1,961 \\
\hline$(1.000,2.000]$ ha & 37 & 0,457 & 0 & 0,000 \\
\hline$(2.000,5.000]$ ha & 14 & 0,173 & 2 & 3,922 \\
\hline$(5.000,10.000]$ ha & 01 & 0,037 & 0 & 0,000 \\
\hline acima de 10.000 ha & 0 & 0,000 & 1 & 1,961 \\
\hline Não informou & & & 2 & 3,922 \\
\hline TOTAL & 8.091 & 100.000 & 51 & 100,000 \\
\hline
\end{tabular}

(*) FONTE: Secretaria de Agricultura e Abastecimento de São Paulo, Projeto LUPA (Informações Econômicas, SP, v. 27, n. 11, nov. 1997).

A estratificação das propriedades amostradas em classes de tamanho de área foi uma das alternativas encontradas para averiguar se o Programa de Fomento Florestal do viveiro da CESP de Porto Primavera atendia a todo tipo de produtor, neste caso, pequenas, médias e grandes propriedades. Utilizou-se a mesma metodologia do Projeto LUPA, Secretaria da Agricultura e Abastecimento de São Paulo (1997), o que possibilitou a comparação da amostra obtida com o os dados do LUPA referentes ao EDR de Assis, como ilustram a TABELA 11 e a FIGURA 2. A amostra segue a tendência da estrutura fundiária revelada pelo censo agropecuário da região. Cerca de metade das 
propriedades, em ambos os casos, concentra-se em apenas duas classes de tamanho, de 10 a 20 , e de 20 a 50 hectares.

Na TABELA 11, ao analisar-se a classe de tamanho das propriedades com área acima de 10.000 ha, encontra-se uma aparente contradição. Segundo esta TABELA, não há no EDR de Assis nenhuma propriedade com área acima de 10.000 ha. Porém, a mesma TABELA indica que foi amostrada uma propriedade com área superior a 10.000 ha, o que não seria possível segundo os dados do Projeto LUPA, Secretaria da Agricultura e Abastecimento de São Paulo (1997), visto que a amostra foi feita com propriedades localizadas naquele EDR. O caso é que esta propriedade é de uma Companhia Agrícola do município de Tarumã, que na verdade é composta por várias fazendas, que juntas somam 20.000 ha.

Este fato relatado no parágrafo anterior serve de alerta para que se analise com cautela os dados referentes à situação fundiária do Estado de São Paulo, apresentadas no Projeto LUPA, Secretaria da Agricultura e Abastecimento de São Paulo (1997) que, ao fazer um levantamento censitário das Unidades de Produção Agropecuária do Estado, encontrou apenas 28 , num total de 277.124 propriedades, com área superior a 10.000 ha. Por mais que se tenha, no Estado de São Paulo, poucas propriedades com área superior a 10.000 ha, deve-se lembrar que uma mesma pessoa ou empresa pode ter várias propriedades, anexas ou não, que se tiverem suas áreas somadas, certamente, resultarão em áreas totais superiores a 10.000 ha. 


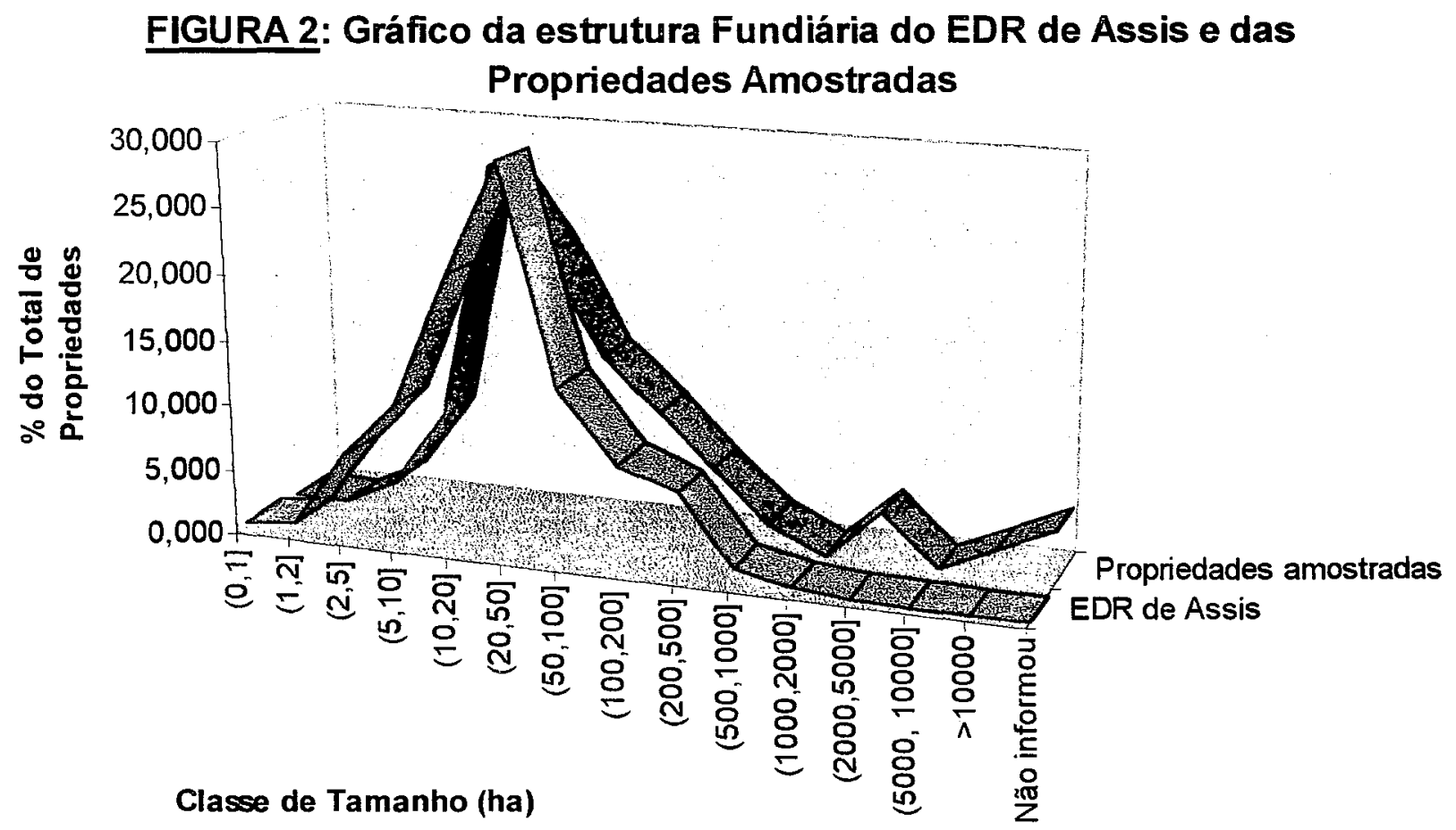

Duas das 51 propriedades amostradas não informaram a sua área total, tendo sido agrupadas à parte, como se pode ver tanto na TABELA 11 quanto na FIGURA 2. A CESP também não dispunha desta informação em seus arquivos.

\subsection{Análise das respostas aos formulários de pesquisa}

Para análise das informações obtidas nos formulários de pesquisa, eles foram tabulados, sendo o resumo apresentado em anexo. No Anexo $H$ estão as respostas fornecidas pelos proprietários com contratos de fomento florestal vigentes (PÚBLICO 1 , 
com as respostas de 35 propriedades). O resumo das respostas da segunda parte do PÚBLICO 1, relativas aos contratos vencidos, encontra-se no Anexo I, com respostas de 6 propriedades. Finalmente, o Anexo $J$ traz o resumo das respostas dos formulários do PÚBLICO 2, contratos desistentes, respondidas por 10 propriedades $(9$ responderam o formulário e 1 enviou apenas uma carta).

Não houve nenhuma resposta aos formulários de pesquisa enviados ao PÚBLICO 3, correspondente aos agricultores não cadastrados no arquivo do Programa de Fomento Florestal do viveiro da CESP de Porto Primavera. Para este grupo foram distribuídos 100 formulários, e esperava-se um retorno semelhante ao obtido para os demais. Pode ter havido falhas na distribuição dos formulários (Casas da Agricultura), ou pode ser que os produtores tenham se sentido intimidados por essa forma de abordagem. Posteriormente, técnicos da Casa da Agricultura de Palmital revelaram que alguns proprietários comentaram ter ficado com receio de sofrer algum tipo de punição dos órgãos de fiscalização a partir de informações que poderiam fornecer ao responderem os formulários.

\subsubsection{A divulgação do Programa}

A primeira pergunta, comuns aos três formulários, tinha o objetivo de identificar de que maneira os proprietários ficaram conhecendo o Programa de Fomento Florestal da CESP. Das 51 propriedades, 34 souberam do Programa através da Casa da Agricultura/CATI, o que representa $66,7 \%$ do total. Apenas 5, ou 9,8\% foram procurados por técnicos da CESP que trabalham no Programa, e outros 2 (3,9\%) através de conversas informais com técnicos que não fazem parte da equipe do Programa. Somente 4 propriedades, ou $7.8 \%$ foram informados do Programa através de material de divulgação da Companhia. 
Uma curiosidade é que tanto nas propriedades com contratos vencidos, quanto nas que desistiram do contrato, apenas 33\% delas conheceram o Programa através da CATI. Já nos contratos vigentes, que são os mais recentes, $82,9 \%$ souberam do Programa por intermédio da CATI. Isto mostra o crescente envolvimento da CATI nas questões referentes ao setor florestal.

Como se pode ver pelas respostas aos formulários, enquanto a divulgação feita diretamente pela CESP foi responsável por $21,5 \%$ dos contatos com os produtores, a CATI foi responsável por $66,7 \%$. Parcerias como esta podem aumentar muito a eficiência do Programa e devem ser estimuladas. Neste caso, a tecnologia de restauração florestal desenvolvida pela empresa, e a quantidade e qualidade das mudas produzidas por ela, podem chegar com mais facilidade e rapidez ao produtor rural, através de uma instituição especializada em extensão rural e que está em contato permanente com o homem do campo, como é o caso da CATI. O inverso também é verdadeiro, ou seja, o conhecimento técnico da CESP poderia ser mais requisitado e utilizado pelas instituições que atuam na extensão rural.

A CESP não tem investido muito na divulgação do seu Programa de Fomento Florestal. De acordo com a equipe do Programa de Fomento Florestal do viveiro da CESP de Porto Primavera, de um modo geral, são os proprietários que procuram a CESP, e que as motivações são variadas, desde aqueles que são pressionados pelo DEPRN (Departamento Estadual de Proteção aos Recursos Naturais) ou pela Promotoria de Justiça, passando por aqueles que querem ter uma propriedade produtiva para contar ponto contra a reforma agrária, até aqueles que fazem isso com o intuito de conservar o solo, a água, a fauna e a flora.

A dificuldade da CESP em contactar os proprietários rurais nas áreas de influência de seus reservatórios é muito grande, principalmente pela falta de equipamentos e corpo 
técnico para a realização da tarefa e pela grande amplitude da área. Assim como neste estudo, a CESP também utilizou-se de correspondências para chegar aos produtores, como revela o seguinte depoimento: "De 1.000 cartas enviadas pela CESP aos proprietários, junto com a conta de energia elétrica, para divulgar o Programa de Fomento Florestal da empresa, apenas uma deu retorno mostrando interesse em participar. Dia de campo com a CATI e o BANESPA é mais eficiente" (Informações fornecidas oralmente por um integrante da equipe técnica de fomento florestal da CESP de Porto Primavera). Enviar carta de divulgação do Programa de Fomento Florestal com a conta de energia elétrica não é um bom procedimento, visto que o simples fato de vir anexada à cobrança deste serviço já pode indispor o destinatário a ler a mesma. Uma divulgação desvinculada da cobrança do serviço de energia elétrica talvez gerasse melhores resultados.

\subsubsection{Motivos que têm levado os produtores a plantar árvores nativas}

Cerca de $60 \%$ dos produtores, ou 31 deles, responderam que têm plantado espécies florestais nativas em suas propriedades para cumprir a lei, sem terem sido autuados ou multados, ao passo que nenhum informou ter plantado após ter sido autuado ou multado. Isso revela uma preocupação desses proprietários em cumprir a lei e evitar problemas com as autoridades ambientais, e não uma motivação espontânea para o plantio.

Em cerca de $75 \%$ das propriedades com área total de até 20 ha, 59\% das com área de 20 a 100 ha e $42 \%$ das propriedades com área superior a 100 ha, um dos motivos indicados para o plantio de nativas foi a preocupação em se cumprir a lei. É interessante se observar que este percentual decresceu em função do aumento da área da propriedade. Muitas vezes o reduzido tamanho de uma pequena propriedade facilita a fiscalização, pois 
pode ser visualizada da estrada de acesso, sem a necessidade de ser adentrada. Já nas grandes propriedades algumas áreas podem ficar menos à vista, dificultando a ação da fiscalização. Além disso, muitas vezes o custo de uma multa pesa mais ao pequeno do que ao grande agricultor.

A força da lei torna-se um mecanismo de persuasão bastante eficiente quando há fiscalização, mas muitas vezes os agricultores se sentem injustiçados, como comprova o seguinte depoimento de um agricultor que desistiu do contrato de fomento: "Essas indicações são porque o DEPRN estão ixigindo junto com P.M. florestal; continuando eu o faço para cumprir a Lei, mas acho injustiça só os agricultores carregar esse fardo, pois as grandes fontes poluidoras nas grandes cidades, com suas enormes fábricas, $e$ esgotos, as autoridades deveriam se preocupar também com as cidades, nós da agricultura estamos descaptalizados devido plano Real, com insumos nas alturas e preços dos nossos produtos lá em baixo. Não podemos pagar sozinhos o reflorestamento" (Propriedade de 13,31 ha em Cândido Mota). Um outro agricultor, com contrato de fomento em vigência fez a seguinte colocação sobre o assunto: "Quanto a CESP não sei, mas órgãos demais chegam multando. ofendendo, sem que a gente saiba de nada, chegam aplicando a multa sem os mesmos sermos avisados. Devíamos ter um pouco mais de diálogo, mas não é assim. Por serem da Lei, acham que podem fazer o que bem entendem, sem a mínima chance pra gente. Isto revolta!" (Propriedade de 41,14 ha em Florínea).

Por outro lado, boa parte dos produtores plantam árvores para conservação dos recursos hídricos (47\% para conservação de margens de rios: $25,5 \%$ para margens de represas e lagos; e 23,5\% para conservação de nascentes), o que já mostra uma preocupação para com a manutenção destes recursos. cada vez mais escassos e muito importantes para qualquer propriedade rural, como reforça o depoimento de um agricultor com contrato de fomento com a CESP em estado de vigência: "...é de suma importância a presença da mata ciliar para a proteção dos mananciais de água. 
Estamos cuidando das árvores plantadas e nossa mata ciliar logo estará formada" (Propriedade de 19,36 ha em Cândido Mota).

$\mathrm{Na}$ conservação dos recursos hídricos, destaca-se o fato de que $75 \%$ das propriedades com área total acima de 100 ha tenham indicado a conservação das margens de rios como a razão para o plantio de espécies nativas, contra $40 \%$ das propriedades com até 20 ha e $41 \%$ daquelas com área entre 20 e 100 ha. Margem de represas, lagos e nascentes foram menos citadas, independentemente do tamanho da propriedade.

Cerca de $30 \%$ dos proprietários (15 propriedades) informaram que a conservação do solo é o que os motiva a plantar árvores em suas propriedades, o que está diretamente ligado com a produção agrícola e, portanto, com a renda da propriedade. Essa motivação foi apontada por $50 \%$ das propriedades com área superior a 100 ha, $35 \%$ pelas com área de 20 a 100 ha, e $15 \%$ pelas propriedades com área menor que 20 ha.

Apenas $11,8 \%$ dos produtores (6 propriedades) citaram a doação de mudas como um dos motivadores para que plantassem árvores em suas áreas, sendo que apenas 2 proprietários, 3,9\% do total, foram motivados pela assistência técnica gratuita prestada pela Companhia. Porém, se for levado em conta o tamanho das propriedades, das $12 \mathrm{com}$ área superior a 100 ha, $4(33 \%)$ assinalaram mudas gratuitas como motivação para o plantio, sendo que em propriedades menores a importância foi consideravelmente menor. É preciso que sejam oferecidos outros atrativos para o produtor rural, de forma que não se pode separar o componente ambiental, do social, e do econômico. Um produtor descapitalizado, sem crédito agrícola, e sem alternativas econômicas à vista, certamente será mais resistente ao plantio de árvores para conservação, alegando redução de área agrícola, altos custos para implantação e manutenção. etc.

Considera-se fundamental que a CESP desenvolva alternativas econômicas para os produtores que estejam baseadas no elemento arbóreo. Nas áreas de preservação 
permanente, onde a forma da floresta é o mais importante (o mais próximo possivel da vegetação original), poderiam ser utilizadas espécies com potencial apícola, por exemplo, o que deveria ser contemplado também pela assistência técnica ao produtor. Para áreas de reserva legal ou fora da área de preservação permanente, onde a função da vegetação é o objetivo principal, muito importantes na conservação do solo e dos recursos hídricos, poderiam ser desenvolvidos modelos passíveis de manejo, com espécies nativas e também exóticas, como por exemplo os sistemas agroflorestais. Isso seria um grande avanço para o Programa de Fomento Florestal da empresa, e certamente teria a adesão de um número bem maior de produtores.

Para incentivar os produtores a reflorestar as margens dos tributários de seus reservatórios, é muito importante que a CESP dê o exemplo aos produtores reflorestando também as margens de suas represas. Esse trabalho vem sendo feito em vários reservatórios da Companhia, porém muitas vezes o público não vê ou não é informado sobre o trabalho que está sendo feito na região, e acha que a empresa não faz aquilo que preconiza em suas áreas, como comprovam os depoimentos: "O Programa é muito burocrático. A CESP precisa dar o exemplo reflorestando a margem da represa capivara" (Eng. Agrônomo que desistiu do contrato de fomento, com propriedade de 200 ha em Assis); "A CESP só planta árvores aonde é só de interesse próprio" (Comerciante que desistiu do contrato de fomento, com propriedade de 16,94 ha em Campos Novos Paulista).

\subsubsection{Situação das margens de rios, córregos e lagos, e das nascentes da propriedade}

Segundo $66,7 \%$ (34 propriedades) dos produtores rurais, boa parte, ou todas as margens de rios, córregos e lagos, e as nascentes de suas propriedades estão protegidas por árvores. Apenas $19,6 \%$, ou 10 propriedades, revelaram que apenas uma pequena 
parte está protegida por árvores, e somente 5,9\% (3 propriedades) que não há nenhum tipo de árvore nestas áreas.

Estas informações não estão de acordo com a situação encontrada na maioria das regiões do Estado, o que sugere que estes valores tenham sido superestimados pelos proprietários, ou que eles julgam que poucas árvores em parte do rio já sejam suficientes para promover a proteção das suas margens. Da mesma forma que alguns produtores não cadastrados no Programa de fomento da CESP que, ao passarem pela Casa da Agricultura de Palmital, não quiseram receber os formulários de pesquisa temendo que os órgãos de fiscalização pudessem utilizar o material para identificar e punir possíveis irregularidades em suas propriedades, estes produtores poderiam estar temerosos por algum tipo de punição. Seriam necessárias visitas a campo para confirmar estas informações, pois a metodologia utilizada neste trabalho não se mostrou eficiente para o levantamento das condições reais em que se encontram as matas ciliares em propriedades particulares.

\subsubsection{Existência de fragmentos de mata na propriedade}

Das 51 propriedades, 17 , ou 33,3\%, disseram que possuíam área de mata, e na maioria das vezes com uma área de 1 a 2,5 ha. Uma das propriedades possui um fragmento com 568 ha. Destes, mais da metade disse que se tratava de mata que não havia sido mexida (explorada).

Pelo que foi possível observar na região nas visitas realizadas, não há muitos fragmentos de matas, e quando existem são pequenos e mal conservados, sujeitos ao fogo e invasão por grandes animais domésticos, como bovinos, eqüinos e muares. 
Cerca de um ano antes do envio dos formulários de pesquisa para as propriedades, havia sido feita uma visita à fazenda que citou o grande fragmento florestal de 568 ha, onde foi possível comprovar a preocupação do proprietário em conservá-lo e uni-lo a outros fragmentos menores. Porém, isso é uma exceção na região, mesmo porque trata-se de uma grande fazenda, cujo proprietário possui outras maiores ainda.

\subsubsection{Alternativas florestais de interesse dos produtores}

As quatro opções mais citadas foram, respectivamente: reflorestamento de margens de rios ( $41,2 \%$, ou 21 propriedades), reflorestamento de proteção a nascentes (35,3\%, ou 18 propriedades), pomar (33,3\%, ou 17 propriedades), e reflorestamento de margens de represas e lagos (29,4\%, ou 15 propriedades). Isso não varou muito com a classe de tamanho das propriedades. Das demais opções, a que mais se destacou foi a de arborização de estradas internas, com $17,6 \%$ (9 propriedades), apontado por quase um terço das propriedades com área total superior a 20 ha.

Plantios comerciais foram pouco citados, sobressaindo o de eucalipto, tanto para uso na propriedade $(15,7 \%$, ou 8 propriedades $)$ quanto para venda $(13,7 \%$, ou 7 propriedades). É interessante destacar que as propriedades maiores tenderam a se interessar mais pelo plantio de eucalipto para venda $(25 \%$ das propriedades com área superior a $100 \mathrm{ha}$ ) do que para o uso da madeira na propriedade ( $8 \%$ das propriedades com área superior a 100 ha). Já as propriedades menores se interessaram mais pelo plantio de eucalipto para uso na propriedade $(25 \%$ das propriedades com área inferior a 20 ha, e 23 das com área entre 20 e 100 ha) do que para a venda da madeira, que por sua vez interessou apenas a 5\% dos proprietários com área inferior a 20 ha. Desta forma o eucalipto parece surgir como uma nova opção econômica para as propriedades médias e grandes, que comercializariam a madeira. e como uma forma de se reduzir gastos com a 
compra de madeira em propriedades menores, que poderiam plantar pequenos talhões, ou renques de árvores.

Menores ainda são as citações de plantios de espécies nativas com fins econômicos (6 propriedades o fariam para uso interno e 2 para venda da madeira), mostrando que os produtores ainda não conhecem esta alternativa, e que é preciso evidenciar melhor essa "economia". Nenhuma propriedade com área inferior a 20 ha indicou o interesse pelo plantio de nativas para venda da madeira, mas $20 \%$ gostariam de plantá-las para usar a madeira na propriedade.

Apenas 2 proprietários falaram do interesse em desmatar novas áreas, ambos pertencentes ao que denominou-se de PÚBLICO 2, ou seja, que desistiram do contrato de fomento florestal.

Arborização de pastagens e quebra-vento não foram citados pelas propriedades menores, mas ambas são de interesse de cerca de $18 \%$ das propriedades com área entre 20 e 100 ha, o mesmo ocorrendo com as de área superior a 100 ha.

\subsubsection{Mão-de-obra utilizada para plantio e manutenção}

Esta questão só estava presente nos formulários enviados ao PÚBLICO 1 (contratos vigentes e vencidos), dos quais 41 foram respondidos.

A mão-de-obra familiar foi utilizada em $46,3 \%$ das propriedades (19 delas), seguida de perto pelas que utilizaram funcionários que já trabalhavam na propriedade, com $36,6 \%$ dos casos. Isso significa que na grande maioria das vezes estas atividades são realizadas por uma mão-de-obra fixa na propriedade e, conseqüentemente, sem 
experiência na área, visto que não se trata de uma região de tradição em atividades florestais. Em alguns casos isso pode interferir negativamente na qualidade dos plantios, mas, por outro lado, pode ser visto como uma oportunidade educativa para estas pessoas, que passaram a conhecer uma atividade nova.

Cerca de $70 \%$ das propriedades com até 20 ha de área utilizaram mão-de-obra familiar para o plantio, sendo que este percentual desceu para $50 \%$ no caso de propriedades com área de 20 a 100 ha, e $10 \%$ para aquelas com área superior a 100 ha. Nestas propriedades maiores o plantio foi feito na grande maioria das vezes $(70 \%)$ por funcionários que já vinham trabalhando em outras atividades na propriedade.

Como mais de $80 \%$ das propriedades utilizam mão-de-obra fixa, que possuem suas atividades rotineiras na propriedade, toda e qualquer ação florestal deve ficar em segundo plano, quando os funcionários não estiverem ocupados com colheita, plantio agrícola, etc. Isso deve ser levado em conta, pois em determinadas épocas do ano, a mãode-obra está toda mobilizada para as atividades produtivas, o que pode por a perder todo um trabalho, caso coincida com o período do plantio ou manutenção florestal.

Apenas $19,5 \%$, ou 8 produtores, utilizaram mão-de-obra contratada especificamente para o trabalho, sendo que, destes, um utilizou mão-de-obra da CESP e um segundo de funcionários contratados pela Casa da Agricultura. Com exceção do pessoal da CESP, muito provavelmente, estes funcionários também não deveriam ter experiência na área, o que pode acarretar alguns problemas, como os que foram levantados por um agricultor com contrato de fomento ainda em vigor com a CESP: "Não sei se os funcionários, contratados pela Casa da Agricultura, que fizeram o plantio receberam alguma explicação da CESP. Em todo caso acredito que não, pois no meu caso eles plantaram muito raso as plantas, que muitas morreram, tive que pegar meus funcionários e replantar nas covas que as mudas morreram e tive que aguar com bomba e trator com mangueira assim resistiram ao veranico que às vezes acontece em 
janeiro, que foi esse caso de 98, e fazer capinagem manualmente, e no meio da rua passar um tritão" (Propriedade de 111,32 ha em Cândido Mota).

\subsubsection{Implantação de reflorestamentos sem a parceria da CESP}

Das 51 propriedades que retornaram os formulários de pesquisa, 21 delas $(41,2 \%)$ informaram ter implantado reflorestamentos sem a parceria da CESP. A maioria deles fez plantios de espécies nativas (beira de rios e açudes, pasto apícola), além de eucalipto (área de encosta, quebra-vento) e grevílea (quebra-vento), em parceria com escolas, DEPRN, Horto Florestal de Assis, Casa da Agricultura, Flora Vale de Assis, e Prefeituras. Alguns citaram a compra de mudas em viveiros comerciais.

Houve um caso em que o produtor, um economista cujo contrato de fomento já havia vencido, conseguiu algumas mudas com a CESP, mas acabou tendo que completar o plantio da área com mudas de outra origem, como comprova o depoimento: " $O$ Programa da CESP era bom. A orientação foi fraca. Fiz duas etapas. Depois foi difícil pegar mudas e optei por pegar mudas aqui perto em Assis. As mudas que peguei na CESP eram boas e teria gostado de continuar a pegar para acabar a margem da represa - faltam ainda $2 \mathrm{~km}$ "(Propriedade de 73 ha em Pedrinhas Paulista).

Às propriedades, com contrato de fomento enquadrados no grupo dos desistentes (PÚBLICO 2), perguntou-se também se após desistirem daquele contrato eles haviam feito outro. Apenas 1 entre 9 respondeu que sim, cerca de 55\% (5 produtores) responderam que não, 2 disseram que quem desistiu foi a CESP que não os procurou mais, e 1 disse ter pedido mudas à CESP para plantar numa encosta e acabou plantando 
eucalipto fornecido pela Casa da Agricultura. Outro agricultor de Cândido Mota que enviou apenas uma carta, não retornando o formulário de pesquisa acrescentou: “... $\mathrm{Na}$ minha propriedade eu plantei árvores de boa qualidade dos matos que tem aqui que eu conheço e outras mudas que peguei no florestal e Casa da Lavoura sem comunicar técnico algum ...".

Ainda para os proprietários que desistiram do contrato de fomento, ao perguntarse se teriam interesse em conversar novamente com a CESP para participar do Programa de fomento florestal, 5 produtores $(55,6 \%)$ responderam que sim, sendo que um deles acrescentou que "sim, mas desde que a CESP ou o próprio Estado dessem ajuda de custo". Apenas $2(22,2 \%)$ responderam que não; 1 disse que "gostaria de saber se eucalipto serve para reflorestamento"; e 1 não respondeu a questão.

As respostas indicam que há outras instituições fomentando o plantio de árvores nativas e exóticas na região, e que há gente disposta inclusive a comprar mudas, o que sugere que a CESP poderia aumentar a produção de mudas para o Programa de Fomento Florestal, se tivesse interesse.

\subsubsection{Participação na escolha das espécies plantadas}

Apenas o PÚBLICO 1, formado por 41 contratos de fomento vencidos e vigentes, respondeu a esta questão.

Somente 7 proprietários, o que representa $17,1 \%$ do total. tiveram a oportunidade de participar da escolha das espécies plantadas. A maioria, $78,0 \%$ ou 32 produtores, não 
teve esta chance, sendo que quase a metade deles (14 proprietários) gostaria de ter participado da escolha. Quando perguntou-se se rejeitaram ou rejeitariam alguma espécie caso tivessem opção, $19,5 \%$ (8 proprietários) disseram que sim, e 78,0\% (32 proprietários) que não. Isso pode sugerir que a CESP tem tomado o cuidado de não fornecer mudas de espécies que possam causar inconvenientes aos produtores.

Aqueles que rejeitaram ou rejeitariam alguma espécie, citaram as seguintes:

- paineira: espécie secundária tardia, longeva, de ampla dispersão, com pouca utilidade econômica, mas utilizada no passado para confecção de travesseiros;

- angico: espécie secundária inicial, bastante comum em algumas regiões, rápido crescimento, flores melíferas, boa para lenha, carvão e carpintaria;

- pau-d'alho: secundária tardia de rápido crescimento, madeira não muito valiosa e empregada em caixotaria e embalagens;

- amoreira-brava: secundária inicial, de rápido crescimento, madeira de boa durabilidade externa, de ampla ocorrência;

- cerejeira: secundária tardia, madeira pesada e bastante utilizada na marcenaria, de odor agradável, e ornamental, de maior ocorrência no nordeste;

- mogno: secundária tardia, madeira muito valiosa e usada na movelaria, nativa da amazônia;

- "mudas muito pouco durativa": entenda-se por pioneiras, de rápido crescimento, e de pouco ou nenhum valor econômico.

Algumas espécies rejeitadas pelos produtores foram uma surpresa para, como a paineira, que foi a única citada duas vezes; e a cerejeira e o mogno, de alto valor madeireiro. Por outro lado, foram citadas várias espécies de rápido crescimento, pioneiras e secundárias iniciais, que ocorrem normalmente em alta densidade de indivíduos, de baixo valor econômico, e que podem invadir áreas agrícolas. Sobre este assunto, perguntou-se também se alguma espécie plantada veio a causar algum tipo de inconveniente, como invasão de área agrícola e pastagem. ou intoxicação de animais. 
Cerca de $66,0 \%$ (27 proprietários) disse não ter tido problemas, ao passo que $14,6 \%$ (6 proprietários) disse que teve problemas com invasão de área agrícola e de pastagem, apesar de não ter citado particularmente nenhuma espécie. Aquilo que cientificamente pode estar correto, do ponto de vista da adoção pode não ser viável, como no caso do leiteiro (Sapium glandulatum (Vell.) Pax.) que pode ser uma excelente pioneira, mas que pode invadir áreas de pastagem anexas ao plantio.

De qualquer forma, para se evitar qualquer tipo de inconveniente, recomenda-se que os proprietários participem de alguma forma da escolha das espécies, pelo menos na exclusão de algumas que eles não queiram. A simples possibilidade de participação na escolha das espécies poderia ser também uma maneira de estimular os produtores a plantar. Nos comentários feitos por pessoas que responderam aos formulários, encontram-se pedidos de mudas de espécies de madeira nobre, frutíferas, que produzam flores ornamentais, e que sejam resistentes na região.

Um bom projeto de revegetação, para uma propriedade agrícola particular, deve começar pelo estabelecimento de uma comunicação entre o técnico responsável e o proprietário da área ou funcionário responsável, de forma que a construção do conhecimento seja fomentada por este diálogo. O projeto, para ter sucesso, precisa contemplar os objetivos do proprietário da área e levar em conta a disponibilidade de fatores como: mão-de-obra, máquinas e implementos, área, recursos financeiros, tempo, etc. Além disso, as pessoas que vivem no local podem ajudar a identificar as espécies nativas que ocorrem naturalmente na região e que, por este motivo, devem estar mais adaptadas àquelas condições. Esta forma de relacionamento entre o técnico e o proprietário rural é bastante discutida em Freire (1983). 


\subsubsection{Compreensão pelo produtor do modelo de plantio da CESP}

Também foi perguntado aos produtores, com contratos de fomento vencidos e vigentes, se eles receberam alguma explicação sobre o modelo de plantio da CESP, que combina de 20 a 30 espécies nativas, e é organizado em linhas de plantas que crescem mais rápido e se desenvolvem bem à pleno sol, ao lado de linhas de plantas que crescem mais lentamente e que têm um desenvolvimento melhor na sombra. Este é um ponto fundamental, para o sucesso do plantio, e do fomento. É fundamental que o produtor saiba o que está fazendo, e que conheça os princípios do modelo para que possa utilizálos em outras áreas de sua propriedade, ou em qualquer outro local.

Apenas 4 dos 41 proprietários, ou 9,8\%, disseram não ter recebido nenhuma explicação sobre o modelo de plantio adotado, e outros 26,8\% (11 proprietários) disseram que apesar de terem recebido explicação, não teriam condições de implantá-lo em outras áreas, por não terem entendido, não lembrarem, etc. Assim, cerca de $36 \%$ dos produtores não tiveram a oportunidade de realmente aprender aqueles conhecimentos para poder usá-los no seu cotidiano.

Um produtor que conhece o papel que as espécies pioneiras desempenham na floresta, e em áreas em que não há mais floresta, não as verá mais apenas como pragas de pasto ou plantas que invadem áreas agrícolas e não servem para nada. Poderá inclusive aproveitá-las em atividades econômicas, como produção de mel, "substrato" para o plantio de espécies econômicas que necessitem de sombra para se desenvolver, como o palmito jussara (Euterpe edulis Mart.), o jequitibá (Cariniana sp.), a peroba-rosa (Aspidosperma polyneuron Muell. Arg.), o cedro-rosa (Cedrela fissilis Vell.), etc. Também poderão começar a enxergar uma capoeira, com apenas espécies pioneiras, como o começo de uma nova floresta, onde no futuro poderão surgir espécies valiosas. 
Por outro lado, 22 produtores rurais, o que representa $53,7 \%$ do total, disseram não só ter recebido a explicação, mas ter entendido e ter condições de implantá-lo em outras áreas. Esta segurança demonstrada por mais da metade dos proprietários cria a expectativa de que alguns deles possam ser agentes multiplicadores desse conhecimento, atingindo um número ainda maior de pessoas.

De qualquer modo, é preciso que a CESP não permita que nenhum produtor fique sem conhecer e entender os princípios básicos que foram utilizados na elaboração do projeto técnico de plantio, de forma que ele possa ter uma ação ativa e uma visão crítica do trabalho que está sendo implantado em suas terras.

\subsubsection{Razões que levaram alguns produtores a desistir do contrato de fomento florestal com a CESP}

Para aqueles que desistiram do contrato de fomento florestal com a CESP, grupo do qual foram recebidos 9 formulários respondidos e uma carta, perguntou-se o motivo pelo qual desistiram, mas não foi possível identificar nenhuma razão que predominasse.

Os motivos diretamente ligados à CESP foram: discordância com os termos do contrato de cooperação; dificuldade em buscar as mudas no viveiro da CESP; a CESP nunca ter retornado ao local depois da primeira visita; demora da CESP para fazer a visita; discordância com o espaçamento de plantio.

Nos documentos a que teve-se acesso, inclusive o modelo do contrato de fomento (conferir Apêndice 2), não está especificada a parte que ficará responsável pelo transporte das mudas. Porém, o que foi ouvido informalmente de membros da equipe técnica de fomento florestal do viveiro de Porto Primavera é que a CESP levaria as mudas e o 
produtor apenas arcaria com custos de plantio e manutenção. $\mathrm{Na} 4^{\mathrm{a}}$ cláusula do contrato de fomento entre a CESP e o proprietário, está escrito que cabe à CESP "fornecer, por sua exclusiva conta, as mudas de essências florestais necessárias à implantação do projeto de reflorestamento, na faixa de proteção".

É importante que fique claro desde o primeiro contato, e que esteja explícito no contrato, todos os direitos e deveres de cada parte, neste caso, a CESP e o proprietário.

Em conversas informais com pessoas da região, inclusive agrônomos da CATI, obteve-se a informação de que em muitos casos a CESP fez uma visita ao produtor e nunca mais voltou para trazer o contrato de fomento, sendo que o nome destes produtores entrou na lista de contratos desistentes. Em dois formulários respondidos foi dito que "quem desistiu do contrato foi a CESP, que não os procurou mais".

\subsubsection{Avaliação do Programa pelo produtor}

Dos 51 proprietários que responderam os formulários de pesquisa, 70,6\% (36 produtores) avaliaram o Programa como sendo de bom a ótimo. Regular foi a avaliação feita por 7,8\% (4 proprietários) e apenas outros 7,8\% disseram que o Programa é péssimo ou muito ruim. Cerca de 11\% (6 proprietários) não responderam a questão.

Apesar da boa aceitação pela maioria do público, há produtores descontentes com o Programa e com o tratamento que receberam da CESP. As maiores reclamações são referentes à dificuldade do produtor em buscar a muda no viveiro, e a falta de retorno da CESP após a primeira visita. Isso mostra que a empresa deve investir mais no contato com o produtor, capacitando melhor os seus técnicos na área de extensão rural, e 
respondendo a todas as solicitações de fomento, mesmo quando a empresa desistir de atuar em determinadas regiões.

Alguns trechos de comentários selecionados dos formulários de pesquisa respondidos pelos produtores retratam a opinião deles sobre o Programa:

"Preciso que a CESP melhore mais o sistema de distribuição de mudas e fiscalização nas áreas..." (Agricultor, contrato vigente, com propriedade de 24 ha em Palmital);

“É um Programa muito bom, pois além de fornecer mudas é também fornecido o sistema de reflorestamento a ser feito na mata ciliar" (Empresário, contrato vigente, com propriedade de 80,72 ha em Tarumã);

“O Programa é muito interessante e deveria ser melhor divulgado..." (Usina, contrato vencido, com propriedade de 2258 ha em Maracaí);

“...É um programa bom e eficiente, no entanto é desejável uma assistência técnica mais intensiva" (Eng. Agrônomo, contrato vencido, com propriedade de 240 ha em Florínea); "O Programa é muito burocrático" (Eng. Agrônomo, contrato desistente, com propriedade de 200 ha em Assis);

"É um programa interessante. Porém, deve ser ampliado e facilitado" (Contrato desistente, com propriedade de 90,75 ha em Paraguaçu Paulista). 


\section{CONCLUSÕES}

O uso de formulários de pesquisa enviados pelo correio, para se conhecer a forma com que o produtor vê as questões relacionadas à presença da árvore e o seu papel na propriedade rural, apresenta uma série de inconvenientes e, certamente, não é a melhor forma de coleta de dados. Erros no registro dos endereços para correspondência, alterações de endereços; o não atendimento do serviço de correios em algumas áreas rurais; a dificuldade de compreensão do formulário; a formalidade desse instrumento de pesquisa e a intimidação que pode proporcionar; e o pequeno espaço disponível para comentários e sugestões, estão entre os maiores problemas. Nada melhor que o contato direto com o objeto de estudo e a oportunidade do diálogo. Porém, em casos como este, onde as propriedades estão muito distantes uma das outras de forma a inviabilizar ou onerar muito a ida ao campo, torna-se uma importante ferramenta para se conhecer mais sobre o universo estudado para que se possa efetuar os devidos recortes e/ou aperfeiçoar as ações.

Avaliando o Programa de Fomento Florestal do viveiro de produção de mudas da CESP de Porto Primavera, nos seus primeiros 10 anos (1988 a 1997), foi possível constatar uma evolução considerável. Hoje a empresa dispõe de um conhecimento técnico muito avançado, testado e aprovado em plantios de mais de 10.000 hectares e em diversos municípios do Estado de São Paulo (IPEF, 1999). São produzidas e plantadas apenas mudas de espécies nativas das regiões de plantio, e o custo de produção de mudas e plantio foi bastante reduzido. Segundo IPEF (1999), o custo de implantação de florestas da CESP diminuiu de US\$ 4 mil por hectare para US\$1,5 mil o hectare. Um 
ponto fraco do fomento florestal realizado pelo viveiro de Porto Primavera, neste período, é que este se encontra muito fragmentado, atendendo a propriedades dispersas em 80 municípios em 4 estados diferentes da federação, o que dificulta as atividades de visita ao local, expedição (saída das mudas) e assistência técnica.

É preciso melhorar o sistema de arquivo de dados referentes aos contratos de fomento, pois muitas informações importantes, que poderiam ajudar na avaliação e aperfeiçoamento do Programa de Fomento do viveiro e na compreensão da realidade em que vive o produtor rural, estão deixando de ser registradas ou sendo perdidas.

A partir dos resultados obtidos, não se pode confirmar a hipótese de que grande parte dos produtores aderiram ao Programa de Fomento principalmente pelo fato de poder receber mudas e assistência técnica gratuitas, o que indica tratar-se de um incentivo necessário, mas não suficiente. Cerca de $41 \%$ das propriedades que responderam aos formulários informaram ter implantado outros reflorestamentos, na maioria com espécies nativas, sem a parceria com a CESP. Alguns proprietários disseram ter comprado mudas de viveiros comerciais.

Verifica-se que a questão legal, aliada ao temor da ação do DEPRN, da Polícia Florestal, Promotoria de Justiça, e demais instituições ligadas ao setor de meio ambiente, foi o motivo principal que levou os produtores rurais a participar do fomento florestal da CESP, na região de Assis. Constatou-se que a pressão legal influenciou mais as propriedades menores. Esta tendência, muito provavelmente, deve se repetir em outras regiões, o que sugere a necessidade da Companhia investir, cada vez mais, no trabalho conjunto com estes órgãos.

Por outro lado, a conservação dos recursos hídricos e do solo também têm motivado muitos produtores para o plantio de espécies florestais nativas, o que indica que os produtores estão preocupados diretamente com a conservação dos recursos naturais, 
mais diretamente ligados à produção agropecuária, disponiveis em suas áreas. Esta tendência foi mais evidente nas grandes do que nas pequenas propriedades.

O exemplo do município de Palmital, onde o produtor pôde ver o compromisso de diversas instituições atuando em parceria na busca de uma melhoria de qualidade de vida para a região, através de ações nas esferas social, econômica e ambiental, é uma alternativa a ser considerada por outros programas de fomento florestal.

Um programa de fomento florestal não é apenas um instrumento para se plantar árvores, mas uma oportunidade de se incentivar a adoção de uma nova postura dos proprietários rurais frente ao elemento arbóreo, e também de buscar novas alternativas que venham a melhorar a qualidade de vida destas pessoas e de toda a sociedade. Não se pode mais promover o trabalho paralelo e independente das várias instituições públicas, com ações fragmentadas e desvinculadas de uma política pública definida. É preciso que haja um compromisso do Estado, assim como um esforço para o trabalho conjunto das diversas instituições, na busca da construção de um modelo de desenvolvimento e uso do solo mais equilibrado. Uma única instituição como a CESP não pode ter a pretensão de resolver sozinha uma questão tão complexa, mas, por outro lado, assumiu o compromisso com a implantação das barragens, desalojando populações, destruindo e alterando ecossistemas, etc.

O Programa de Fomento Florestal do viveiro da CESP de Porto Primavera não oferece muitos incentivos ao produtor, além das mudas e assistência técnica gratuitas. Não há, por exemplo, redução no preço da energia elétrica cobrado àquele que restaurar áreas diretamente ligadas aos reservatórios da Companhia, ou outras formas de premiar as iniciativas que venham a aumentar a vida útil dos reservatórios e melhorar a qualidade da água. Em alguns casos, até mesmo o transporte das mudas fica por conta do fomentado, que ainda tem que arcar com os custos de implantação e manutenção. 
O principal enfoque do Programa de Fomento Florestal do viveiro de Porto Primavera está na produção de mudas, aproveitando toda a estrutura física do viveiro, que tem capacidade para produzir muito mais mudas de boa qualidade genética e fisiológica, do que a Companhia tem capacidade de plantar. A maior dificuldade está na efetivação do plantio, tanto em áreas da Companhia quanto em propriedades particulares. Neste sentido, o Programa deveria se ater mais às ações de divulgação, sensibilização do produtor rural, e busca de alternativas que possibilitasse a presença do elemento arbóreo na propriedade agrícola, tanto como componente econômico quanto ambiental.

Como sugestões para aperfeiçoamento do Programa, a partir do que foi levantado pela pesquisa realizada nos municípios da região de Assis, é possível citar:

a) O estabelecimento de parceiras com outras instituições, governamentais ou não, principalmente para o desenvolvimento de ações de extensão florestal, visto que há instituições mais equipadas e aptas para isso. Seria importante uma parceria formal com a CATI, para divulgação do Programa através dos técnicos das Casas da Agricultura, do Programa de Micro Bacias, Programa "Margem Verde" e outros. A CESP poderia treinar os extensionistas da CATI para fazer a divulgação e a assistência técnica com o produtor rural;

b) $\mathrm{O}$ desenvolvimento de modelos de reflorestamento que também sejam alternativas econômicas para o produtor rural, mesmo que para a implantação em áreas que não sejam de preservação permanente, de forma a incentivar a presença da árvore na propriedade, além de oferecer uma alternativa econômica;

c) Levar em conta o calendário agrícola da região na distribuição das mudas, para evitar perdas por falta de mão-de-obra para o plantio e manutenção, principalmente no caso das propriedades pequenas, que se utilizam basicamente da mão-de-obra familiar; 
d) Incentivar a participação dos produtores na elaboração do projeto técnico de reflorestamento. ou seja, da escolha das espécies a serem plantadas, do espaçamento de plantio, etc., dentro dos procedimentos técnicos adequados. O proprietário da área deve ser visto como um parceiro, e não como um objeto do Programa. Assim, poderá compreender melhor o trabalho e ter um maior compromisso para com ele;

e) Definir quais são as micro bacias mais críticas, dentro das bacias hidrográficas onde estão localizados os reservatórios da Companhia e os rios tributários, e concentrar o fomento nestas áreas, facilitando a operacionalidade do Programa;

f) Desenvolver ações específicas para cada região, ou reservatório, de forma a atender melhor às demandas locais, ao passo de se trabalhar com apenas uma metodologia para realidades distintas.

Finalizando, é importante destacar que, mais do que a repressão, as informações obtidas a partir desta pesquisa indicam que o incentivo à adoção do elemento arbóreo na propriedade rural, desenvolvendo-se alternativas florestais que respondam às demandas do produtor, são o melhor caminho para o crescimento do Programa de Fomento Florestal na região. O modelo de reflorestamento misto com espécies nativas desenvolvido pela CESP, mais do que um modelo de implantação de um trecho de mata ciliar dentro de uma propriedade, é uma oportunidade para que se veja a árvore e a floresta com outros olhos. Conhecendo a dinâmica da floresta, a função de cada árvore no sistema, técnicas de plantio e manejo, o proprietário pode entender melhor o ambiente em que vive, e conviver com a natureza, sem agredi-la e sem sofrer as conseqüências de um manejo incorreto. Compreendendo os princípios do modelo, que nada mais são do que a aplicação da própria diversidade e dinâmica da floresta tropical, o produtor pode participar ativamente da elaboração do projeto técnico de plantio, pois conhece o clima, o solo, os animais e as plantas da região. E, assim, potencializar os efeitos da assistência técnica dentro do programa de fomento. 
ANEXO A: Carta de apresentação e intenções ao Diretor de Meio Ambiente da CESP.

Piracicaba - SP, 18 de julho de 1997.

Ilmo. Sr. Daniel Antonio Salati Marcondes

Diretor de Meio Ambiente da Companhia Energética do Estado de São Paulo (Cesp)

Como parte de um projeto de dissertação, ligado ao curso de mestrado em Ciências Florestais da ESALQ/USP, intitulado "Avaliação de Plantios Mistos de Espécies Nativas em Propriedades Rurais, no Entorno de Reservatórios da Cesp", conforme projeto em anexo, o aluno André Rocha Ferretti, sob a orientação do Prof. Dr. Paulo Yoshio Kageyama e do Prof. Dr. Oriowaldo Queda, vem por meio desta pedir à Companhia Energética de São Paulo (Cesp), uma autorização para a avaliação de alguns de seus plantios mistos de espécies nativas no entorno do reservatório da unidade de Porto Primavera (Rosana - SP).

Os principais objetivos desta dissertação são: avaliar os plantios mistos de espécies nativas em propriedades rurais atendidas pelo fomento florestal da Cesp, na unidade de Porto Primavera, tendo como referência os reflorestamentos implantados nas áreas da própria empresa; identificar possíveis causas do sucesso ou insucesso dos reflorestamentos nas propriedades particulares fomentadas; conhecer melhor o desenvolvimento das diferentes espécies utilizadas nos plantios, bem como dos diferentes grupos sucessionais e as relações entre eles; e fornecer elementos que possam contribuir para melhorar o programa de fomento da Cesp.

A reconhecida qualidade dos plantios mistos de espécies nativas realizados pela Cesp no entorno de seus reservatórios, a extensão da área efetivamente plantada, e a tecnologia desenvolvida pela empresa desde a coleta de sementes até o estabelecimento da floresta, faz com que a Cesp seja uma referência para qualquer programa de revegetação com espécies nativas no Brasil. 
A avaliação desses plantios instalados em propriedades particulares fomentadas pela Cesp é uma tarefa bastante importante, visto que os mesmos apresentam a característica de poderem ser reproduzidos em outros locais caso tenham obtido sucesso no seu desenvolvimento. Além disso, o contato com os produtores pode fornecer informações que venham a contribuir para aperfeiçoar ainda mais o programa de fomento florestal da Cesp.

É importante destacar a colaboração do Prof. Dr. Oriowaldo Queda, Departamento de Economia e Sociologia Rural da ESALQ/USP, no tocante ao aspecto da forma de abordagem aos produtores rurais, bem como de aspectos sócio-cuiturais e análise da relação homem-natureza.

Gostaríamos de enfatizar que não haverá nenhum tipo de ônus para a Cesp, contanto o mestrando com bolsa concedida pela CAPES para o desenvolvimento do projeto, além de recursos próprios. Contamos também com algum recurso para transporte e alojamento proveniente do Projeto "Florestas Sociais: o elemento arbóreo nas unidades rurais", junto ao convênio Fundação Florestal/Instituto Florestal/ESALQ-USP-LCF-IPEF, do qual participa juntamente com outros alunos de mestrado, professores e estagiários do curso de graduação em Engenharia Florestal da ESALQ/USP.

A análise dos dados será realizada no Departamento de Ciências Florestais da ESALQ/USP, que também fornecerá os equipamentos necessários para a avaliação dos experimentos, como trena, fita dendrométrica. suta, etc.

Certos de contar com vossa compreensão, agradecemos desde já a vossa atenção,

Eng. Florestal André Rocha Ferretti Aluno de mestrado da ESLAQ/USP
Paulo Yoshio Kageyama

Orientador 
ANEXO B: Carta de autorização da CESP para o desenvolvimento do trabalho.

Dato

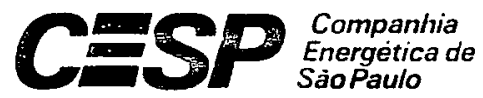

Ref. CESP CT/M/4425/97

São Paulo, 12 de setembro de 1997

IImo. Sr.

Prof. Dr. Paulo Yoshio Kageyama

Departamento de Ciências Florestais

Escola Superior de Agricultura Luiz de Queiroz

Caixa Postal 9

Piracicaba - SP

Prezado Senhor,

Em atenção a carta datada de 18/7/97, solicitando-nos autorização para a avaliação de alguns plantios de espécies nativas, integrantes do fomento florestal praticado pela CESP na região de Porto Primavera, ou entāo Promissão, que é bem mais próxima e de melhor acesso, como suporte para o desenvolvimento de dissertação de mestrado orientada por V.Sa. e pelo Prof. Orivaldo Queda, temos a considerar o que segue.

Acreditamos que o tema proposto para o desenvolvimento da referida dissertação representa uma oportunidade interessante par a realizaçāo de um diagnóstico concebido mediante metodologia cientifica, enfocando o fomento florestal através da análise dos seus compartimentos: ambientais, silviculturais, sócio-econômicos e legais, entre outros.

Tais resultados certamente teriam aplicaçōes práticas pela Companhia no auxilio do planejamento estratégico da atividade com o propósito de aperfeiçoamento continuo da mesma.

Näo obstante um produto com essas caracteristicas possa ter interesse institucional, o desenvolvimento do mesmo requer a consideração de algumas questóes corporativas, como, por exemplo, a citação do nome da CESP no corpo do trabalho, o encaminhamento do plano de dissertação, a comunicaçäo prévia das visitas ao campo, além do envio do trabalho concluido.
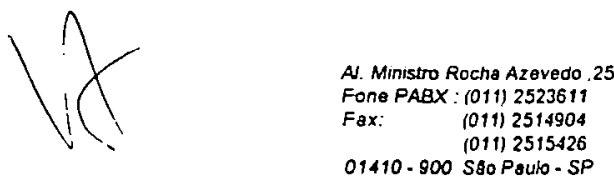
Telex: 1131004 CESP BR 1130496 CESP BR 1131930 CESP BR 1134420 CESP BR

- segue 01410 - 900 S80 Psulo-SP 


\section{Companivia SàoPaulo}

Gostariamos de sugerir ao orientado que procurasse conhecer as publicaçōes mais recentes que abordam o fomento florestal praticado pela CESP, com o intuito de melhor conceituá-lo, visto que a bibliografia consultada (Fernandes, O.R. 1985), näo reflete com exatidão o trabalho atual. Finalizando, acreditamos ser oportuna uma abordagem dos aspectos legais que permeiam o cenario do fomento florestal envolvendo os conceitos de preservação permanente, reserva legal, além das resoluçōes do CONAMA referentes ao assunto.

Atenciosamente,

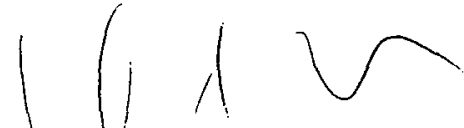

Daniel António Salati Marcondes

Diretor de'Meio Ambiente 
ANEXO C: Formulário de pesquisa para o PÚBLICO 1

\title{
Formulário para levantamento sobre o Programa de Fomento Florestal da CESP na região do Reservatório de Porto Primavera
}

\author{
André Rocha Ferretti (versão 2.1)
}

\author{
PÚBLICO 1 (contratos de fomento vigentes e vencidos)
}

Nome do proprietário:

Nome da propriedade:

Tamanho da propriedade:

Endereço para contato:

Telefone para contato:

1) Como ficou sabendo do programa de fomento florestal da CESP?

( ) Através da Casa da Agricultura (CATI)

( ) Foi procurado por um técnico da CESP

( ) Através de outro produtor rural

( ) Rádio; ( ) Televisão

( ) Recebeu algum folheto ou material de divulgação da CESP

( ) Banco financiador

( ) Pela Prefeitura

( ) Outros (escreva se necessario):

2) Por que você optou pelo plantio de árvores nativas em sua propriedade?

( ) Para cumprir a lei, sem ter sido advertido, autuado ou multado

( ) Para cumprir a lei, depois de ter sido advertido, autuado ou multado

( ) Reserva de madeira; ( ) outros produtos florestais

( ) Paisagismo da propriedade

( ) Mudas; ( ) assistência técnica gratuita fornecidas pela CESP

Conservação de recursos hídricos: ( )nascentes, ( )margens de rios ( )margens de represas e lagos

( ) Conservação do solo

( ) Abrigo para animais; ( ) controle de pragas

( ) Seguiu o exemplo de outras propriedades

( ) Outros (escreva se necessário): 
3) A mão-de-obra utilizada para a abertura das covas, plantio e manutenção foi:

( ) Familiar (família do proprietário da terra)

( ) Funcionários que já trabalhavam na propriedade

( ) Mão-de-obra contratada especialmente para este serviço

( ) Outros (escreva se necessário):

4) Você participou da escolha das espécies de árvores plantadas na sua propriedade?

( ) $\operatorname{Sim}$

( ) Não

( ) Não, mas gostaria de ter participado da escolha

Obs. (se houver) :

5) Você rejeitou ou, caso tivesse tido a opção, rejeitaria algumas das espécies de árvores indicadas pela CESP?

( ) Sim. Quais?

( ) Não

6) O modelo de plantio da CESP combina o plantio de 20 a 30 espécies de árvores nativas da região. Esse plantio é organizado em linhas de plantas que crescem mais rapidamente ao lado de linhas de plantas que crescem mais devagar e que gostam de sombra. O proprietário ou algum responsável pelo plantio recebeu explicações da CESP sobre esse modelo de reflorestamento?

( ) Não recebeu nenhuma explicação

( ) Recebeu explicação, mas não entendeu

( ) Recebeu explicação, mas não lembra

( ) Recebeu explicação, entendeu o modelo de plantio, mas não teria condições de implantá-lo em outras áreas

( ) Recebeu explicação, entendeu o modelo de plantio, e teria condições de implantá-lo em outras áreas

7) Algumas das espécies adotadas no plantio causaram algum tipo de inconveniente: ( )invasão de pastagem; ( )invasão de área agrícola; ( )intoxicação de animais?

( ) Sim. Quais as espécies?

( )Não

8) Na sua propriedade foi feito algum tipo de reflorestamento sem a parceria com a CESP?

( ) Sim. Descreva-o:

( ) Não 
9) Como estão as margens de rios, córregos e lagos, e as nascentes presentes na sua propriedade?

( ) Estão todas protegidas por árvores

( ) Boa parte está protegida por árvores

( ) Uma pequena parte possui árvores

( ) Não há nenhum tipo de árvore nestas áreas

Obs. (se houver):

10) Há alguma área (capão) de mata na sua propriedade?

( ) Sim. Qual o tamanho?

( ) Não

Esta mata é: ( ) mata virgem ( ) mata mexida (explorada)

11) Como você avalia o programa de fomento florestal da CESP?

( )Ótimo ( )Muito bom ( )Bom ( )Regular ( )Ruim ( )Muito ruim ( )Péssimo

12) Marque as aiternativas que você teria interesse em adotar em sua propriedade:

Plantio de eucalipto: ( ) para venda; ( ) para uso na propriedade

Plantio de espécies arbóreas nativas de valor econômico: ( )para venda; ( )para uso na propriedade

Reflorestamento de: ( )margens de rios; ( )margens de represas e lagos; ( )proteção de nascentes

( ) Arborização de pastagem

( ) Cerca viva

( ) Quebra-vento

( ) Sistema agroflorestal (plantio consorciado de árvores e culturas agrícolas)

( ) Pomar

( ) Arborização de estradas internas

( ) Desmatar novas áreas na propriedade

( ) Outros (escreva se necessário):

13) Você teria algum comentário a mais sobre o programa de fomento florestal da CESP? 
ANEXO D: Formulário de pesquisa para o PÚBLICO 2

\title{
Formulário para levantamento sobre o Programa de Fomento Florestal da CESP na região do Reservatório de Porto Primavera
}

André Rocha Ferretti (versão 2.0)

\begin{abstract}
PÚBLICO 2 (propriedades que desistiram do contrato com a CESP)
\end{abstract}
Nome do proprietário:

Nome da propriedade:

Tamanho da propriedade:

Endereço para contato:

Telefone para contato:

1) Como ficou sabendo do programa de fomento florestal da CESP?

( ) Através da Casa da Agricultura (CATI)

( ) Foi procurado por um técnico da CESP

( ) Através de outro produtor rural

( ) Rádio; ( ) Televisão

( ) Recebeu algum folheto ou material de divulgação da CESP

( ) Banco financiador

( ) Pela Prefeitura

( ) Outros (escreva se necessário):

2) Por que plantar árvores nativas em sua propriedade?

( ) Para cumprir a lei, sem ter sido advertido, autuado, ou multado

( ) Para cumprir a lei, depois de ter sido advertido, autuado, ou multado

( ) Reserva de madeira; ( ) outros produtos florestais

( ) Paisagismo da propriedade

( ) Mudas; ( ) assistência técnica gratuita fornecidas pela CESP

Conservação de recursos hídricos: ( )nascentes, ( )margens de rios ( )margens de represas e lagos

( ) Conservação do solo

( ) Abrigo para animais; ( ) controle de pragas

( ) Seguiu o exemplo de outras propriedades

( ) Outros (escreva se necessario): 
3) Por que você desistiu de participar do Programa de Fomento Florestal da CESP?

( ) Não concordou com os termos do contrato de cooperação entre a CESP e o proprietário

( ) Não gostou da conversa com o técnico da CESP que fez a visita a propriedade

Custos: ( ) plantio; ( ) manutenção, muito elevados para o proprietário

Demora da CESP para: ( )fazer a visita; ( )assinar o contrato de cooperação

Não concordou com o modelo de plantio indicado pela CESP: ( )espaçamento; ( )disposição das mudas; ( )espécies arbóreas

Falta de: ( ) tempo; ( ) mão-de-obra, para o plantio e manutenção

( ) Outros (escreva se necessário):

4) $\mathrm{Na}$ sua propriedade foi feito algum tipo de reflorestamento sem a parceria com a CESP?

( ) Sim. Descreva-o:

( ) Não

5) Como estão as margens de rios, córregos e lagos, e as nascentes presentes na sua propriedade?

( ) Estão todas protegidas por árvores

( ) Boa parte está protegida por árvores

( ) Uma pequena parte possui árvores

( ) Não há nenhum tipo de árvore nestas áreas

Obs. (se houver) :

6) Há algum área (capão) de mata na sua propriedade?

( ) Sim. Qual o tamanho?

( ) Não

Esta mata é: ( ) mata virgem ( ) mata mexida (explorada)

7) Após ter desistido deste contrato de cooperação com a CESP, você fez outro contrato?

( ) Sim, mas voltei a desistir

( ) Sim, e ainda estou fazendo o plantio

( ) Sim, e já terminei o plantio

( ) Não

Obs. (se houver) : 
8) Você teria interesse em conversar novamente com a CESP para participar do Programa de Fomento Florestal da Companhia?

( ) $\mathrm{Sim}$

( ) Não

Obs. (se houver) :

9) Como você avalia o programa de fomento florestal da CESP?

( )Ótimo ( )Muito bom ( )Bom ( )Regular ( )Ruim ( )Muito ruim ( )Péssimo

10) Marque as alternativas que você teria interesse em adotar em sua propriedade Plantio de eucalipto: ( ) para venda; ( ) para uso na propriedade Plantio de espécies arbóreas nativas de valor econômico: ( )para venda; ( )para uso na propriedade

Reflorestamento de: ( )margens de rios; ( )margens de represas e lagos; ( )proteção de nascentes

( ) Arborização de pastagem

( ) Cerca viva

( ) Quebra-vento

( ) Sistema agroflorestal (plantio consorciado de árvores e culturas agrícolas)

( ) Pomar

( ) Arborização de estradas internas

( ) Desmatar novas áreas na propriedade

( ) Outros (escreva se necessário):

11) Você teria algum comentário a mais sobre o programa de fomento florestal da CESP? 
ANEXO E: Formulário de pesquisa para o PÚBLICO 3

\section{Formulário para levantamento sobre o Programa de Fomento Florestal da CESP na região do Reservatório de Porto Primavera}

André Rocha Ferretti (versão 2.0)

PÚBLICO 3 (propriedades não cadastradas no programa de fomento da CESP)

Nome do proprietário:

Nome da propriedade:

Tamanho da propriedade:

Endereço para contato:

Telefone para contato:

1) Você já ouviu falar sobre o Programa de Fomento Florestal da CESP?

( ) $\operatorname{Sim}$ (vá para a questão n. ${ }^{\circ}$ )

( . ) Não (và para a questão n. ${ }^{\circ}$ )

Obs. (se houver) :

2) Se você já conhece, como ficou sabendo do programa de fomento florestal da CESP?

( ) Através da Casa da Agricultura (CATI)

( ) Foi procurado por um técnico da CESP

( ) Através de outro produtor rural

( ) Rádio; ( ) Televisão

( ) Recebeu algum folheto ou material de divulgação da CESP

( ) Banco financiador

( ) Pela Prefeitura

( ) Outros (escreva se necessário):

3) Você sabia que, através do seu Programa de Fomento Florestal, a CESP pode fornecer: ( )o projeto técnico; ( ) assistência técnica total; ( ) mudas de essências florestais nativas; ( )transporte destas mudas até a área de plantio, para as propriedades rurais que tenham interesse em recompor matas ciliares de proteção aos seus reservatórios e às nascentes, córregos e rios que neles deságuam, cabendo ao proprietário apenas o plantio e a condução do reflorestamento?

( ) Sim. Por que não participou? 
4) Você conhece alguma propriedade rural que tenha participado do Programa de Fomento Florestal da CESP?

( ) Sim
( ) Não

5) Você já fez algum tipo de reflorestamento em sua propriedade?

( ) Sim, para produção de madeira

( ) Sim, com função de paisagismo

Sim, como: ( )cerca viva; ( ) quebra-vento

Sim, com o objetivo de: ( ) conservação de solos; ( ) proteção de rios; ( ) proteção de lagos e represas; ( ) proteção de nascentes

( ) Não

( ) Outros (escreva se necessario):

6) Como estão as margens de rios, córregos e lagos, e as nascentes presentes na sua propriedade?

( ) Estão todas protegidas por árvores

( ) Boa parte está protegida por árvores

( ) Uma pequena parte possui árvores

( ) Não há nenhum tipo de árvore nestas áreas

Obs. (se houver) :

7) Há alguma área (capão) de mata na sua propriedade?

( ) Sim. Qual o tamanho?

( ) Não

Esta mata é: ( ) mata virgem ( ) mata mexida (explorada)

8) Marque as alternativas florestais que você teria interesse em adotar em sua propriedade:

Plantio de eucalipto: ( ) para venda; ( ) para uso na propriedade

Plantio de espécies arbóreas nativas de valor econômico: ( )para venda; ( )para uso na propriedade

Reflorestamento de: ( )margens de rios; ( )margens de represas e lagos; ( )proteção de nascentes

( ) Arborização de pastagem

( ) Cerca viva

( ) Quebra-vento

( ) Sistema agroflorestal (plantio consorciado de árvores e culturas agrícolas)

( ) Pomar

( ) Arborização de estradas internas

( ) Desmatar novas áreas na propriedade

( ) Outros (escreva se necessário): 
9) Você gostaria de receber mais informações sobre o Programa de Fomento Florestal da CESP?

( ) $\mathrm{Sim}$

( ) Não

10) Você teria alguma sugestão para a divulgação do Programa de Fomento Florestal da CESP? 


\title{
ANEXO F: Carta ao proprietário rural fomentado pela CESP
}

Piracicaba - SP. 28 de setembro de 1998.

Prezado senhor(a),

Sou Engenheiro Florestal e estou fazendo curso de Pós-graduação - Mestrado em Ciências Florestais na Escola Superior de Agricultura "Luiz de Queiroz", da Universidade de São Paulo (ESALQ/USP).

Para concluir o Mestrado estou fazendo um estudo sobre os motivos que levaram os produtores rurais da região de influência da Unidade da CESP de Porto Primavera, a realizar ou não plantios de árvores nativas em suas propriedades. Estarei avaliando também o próprio programa de incentivo ao plantio de árvores nativas desenvolvido pela CESP, chamado "Programa de Fomento Florestal". Isso para que se possa fazer proposições de como desenvolver um programa de reflorestamento com nativas que realmente funcione.

Sou estudante e não trabalho para a CESP. Fui autorizado por esta Companhia. através do seu Diretor de Meio Ambiente, a desenvolver este estudo. Para tanto. a CESP me permitiu consultar seus arquivos e todo o material referente ao "Programa de Fomento Florestal". Assim. foi possível estudar a documentação referente às mais de 500 propriedades rurais, distribuídas em 80 municípios, que até hoje participaram deste Programa. Neste grupo estão incluídas também aquelas que desistiram do Programa. Porém, para avaliar melhor o alcance do "Programa de Fomento Florestal da CESP" na região. também estaremos incluindo, no estudo, propriedades rurais que nunca participaram do Programa.

É importante destacar que em nenhum momento será revelado o nome dos proprietários ou das propriedades envolvidas neste estudo. Os dados específicos de cada propriedade são todos confidenciais. No trabalho final constará apenas dados gerais, como por exemplo o que a maioria dos proprietários rurais acha do Programa de Fomento Florestal da CESP, ou os principais motivos que levaram os proprietários a plantar árvores em suas propriedades ou a desistir do Programa.

Junto com esta carta estou enviado um formulário para ser preenchido pelo proprietário ou funcionário responsável, tanto no caso das propriedades que participam ou participaram do "Programa de Fomento Florestal da CESP", quanto daquelas que nunca participaram.

Para realizar este trabalho preciso da sua ajuda. Afinal, é você, proprietário rural quem melhor conhece o dia-a-dia do homem do campo, suas necessidades e seus interesses. Minha intenção é conhecer melhor o que os produtores rurais desta região pensam sobre a questão tlorestal, para que possam ser melhor atendidos no futuro. Sei que seu tempo é precioso. Peço sua ajuda e compreensão, preenchendo o formulário que acompanha esta carta. Para não tomar mais do seu tempo, estou enviando um envelope selado, já endereçado, que só precisa ser colocado numa caixa de correio. Para preencher o formulário. basta marcar com um "X" sempre que aparecer este símbolo "( )". Não se preocupe, pois não existe resposta certa ou errada.

A minha intenção é a de terminar todo o trabalho até julho de 1999, e para isso preciso que sua resposta me seja remetida no prazo máximo de três semanas após o recebimento desta (final do mês de outubro de 1998). Comprometo-me a enviar resumo do trabalho final e principais resultados para os que participarem da pesquisa.

Agradeço sua atenção e colaboração. fundamentais para a realização deste estudo.

Atenciosamente.

\author{
André Rocha Ferretti \\ Av. Rio das Pedras. n. ${ }^{\circ} 1908$ - Casa 9 - Vila Prudente \\ Piracicaba - SP - CEP. 13425-380
}


ANEXO G: Lista de municípios com contratos de fomento florestal com o viveiro da CESP de Porto Primavera até dezembro de 1997.

\begin{tabular}{|c|c|c|c|c|c|c|}
\hline $\begin{array}{|ll|}\text { Município } & \mathrm{da} \\
\text { propriedade } & \mathrm{do} \\
\text { contrato } & \mathrm{de} \\
\text { fomento } & \\
\end{array}$ & EDR & Estado & \begin{tabular}{|l|} 
Contratos \\
Vigentes
\end{tabular} & \begin{tabular}{|l|} 
Contratos \\
Vencidos
\end{tabular} & $\begin{array}{l}\text { Contratos } \\
\text { Desistentes }\end{array}$ & Total \\
\hline Adamantina & Dracena & $\mathrm{SP}$ & 2 & 1 & 0 & 3 \\
\hline \begin{tabular}{|l} 
Álvares \\
Machado
\end{tabular} & $\begin{array}{l}\text { Presidente } \\
\text { Prudente }\end{array}$ & SP & 1 & 4 & 0 & 5 \\
\hline Anaurilândia & E & MS & 0 & 0 & 1 & 1 \\
\hline Anhumas & \begin{tabular}{|l} 
Presidente \\
Prudente
\end{tabular} & SP & 0 & 0 & 3 & 3 \\
\hline Assis & Assis & SP & 38 & 3 & 4 & 45 \\
\hline Arapongas & - & PR & 0 & 1) & 0 & 1 \\
\hline Avaré & Avaré & SP & 2 & 0 & 0 & 2 \\
\hline Bataiporã & E & MS & $1]$ & 1 & 1 & 3 \\
\hline Caiuá & $\begin{array}{l}\text { Presidente } \\
\text { Venceslau }\end{array}$ & $\mathrm{SP}$ & 1 & 0 & 0 & 1) \\
\hline Cambará & - & PR & 0 & 0 & 2 & 2 \\
\hline $\begin{array}{|ll|}\text { Campos } & \text { Novos } \\
\text { Paulista } & \\
\end{array}$ & Assis & SP & 0 & 0 & 5 & 5 \\
\hline Cândido Mota & Assis & SP & 47 & 19 & 42 & 108 \\
\hline Cerqueira César & Avaré & SP & 0 & 0 & 1 & 1 \\
\hline Colorado & - & PR & 0 & 1 & 0 & 1 \\
\hline Cruzália & Assis & SP & 0 & 1 & 0 & 1 \\
\hline Dracena & Dracena & SP & 0 & 1 & 2 & 3 \\
\hline Estrela do Norte & $\begin{array}{l}\text { Presesidente } \\
\text { Prudente }\end{array}$ & SP & 8 & 1 & 1 & 10 \\
\hline \begin{tabular}{|l} 
Euclides \\
Cunha
\end{tabular} & $\begin{array}{l}\text { Presidente } \\
\text { Venceslau }\end{array}$ & SP & 6 & 1 & 0 & 7 \\
\hline Fartura & Ourinhos & SP & 2 & 0 & 1 & 3 \\
\hline Flórida Paulista & Dracena & SP & 1 & 1 & 0 & 2 \\
\hline Florínea & Assis & SP & 7 & 25 & 15 & 47 \\
\hline Herculândia & Tupã & SP & 0 & 0 & 1 & 1 \\
\hline Ibiporã & - & PR & 0 & 1 & 0 & ) \\
\hline Ibirarema & Assis & SP & 0 & 0 & 1 & 1 \\
\hline Iêpe & $\begin{array}{l}\text { Presidente } \\
\text { Prudente }\end{array}$ & SP & 0 & $1]$ & 3 & 3 \\
\hline Indiana & $\begin{array}{l}\text { Presidente } \\
\text { Prudente }\end{array}$ & SP & 0 & 1 & 0 & ) \\
\hline Inúbia Paulista & Tupã & SP & 0 & 2 & 0 & ) \\
\hline Itaguajé & - & PR & 0 & 0 & 1 & 1 \\
\hline
\end{tabular}




\begin{tabular}{|c|c|c|c|c|c|c|}
\hline $\begin{array}{ll}\text { Município } & \text { da } \\
\text { propriedade } & \text { do } \\
\text { contrato } & \text { de } \\
\text { fomento } & \\
\end{array}$ & EDR & Estado & $\left|\begin{array}{l}\text { Contratos } \\
\text { Vigentes }\end{array}\right|$ & $\left|\begin{array}{l}\text { Contratos } \\
\text { Vencidos }\end{array}\right|$ & $\left|\begin{array}{l}\text { Contratos } \\
\text { Desistentes }\end{array}\right|$ & Total \\
\hline Itaí & Avaré & SP & 3 & 0 & 0 & 3 \\
\hline Itatinga & Botucatu & SP & 1 & 0 & 0 & 1 \\
\hline Jacarezinho & - & PR & 1 & 0 & 0 & 1 \\
\hline Jaraguari & - & MS & 1 & 0 & 0 & 1 \\
\hline Junqueirópolis & Dracena & SP & 1 & 2 & 0 & 3 \\
\hline Lucélia & Tupã & SP & 1 & 3 & 2 & 6 \\
\hline Lupércio & Marília & SP & 0 & 1 & 0 & 1 \\
\hline Lupionópolis & - & PR & 5 & 0 & 1 & 6 \\
\hline Marabá Paulista & $\begin{array}{l}\text { Presidente } \\
\text { Venceslau }\end{array}$ & SP & 14 & 0 & 0 & 14 \\
\hline Maracaí & Assis & SP & 3 & 8 & 0 & 11 \\
\hline Maringá & - & PR & 3 & 0 & 0 & 3 \\
\hline \begin{tabular}{|l|} 
Mirante do \\
Paranapanema
\end{tabular} & $\begin{array}{l}\text { Presidente } \\
\text { Venceslau }\end{array}$ & SP & 0 & 0 & 2 & 2 \\
\hline Moema & - & MG & 0 & 0 & 1 & 1 \\
\hline Nantes & \begin{tabular}{|l|} 
Presidente \\
Prudente
\end{tabular} & SP & 1 & 0 & 0 & 1 \\
\hline Narandiba & $\begin{array}{l}\text { Presidente } \\
\text { Prudente }\end{array}$ & SP & 0 & 1 & 1 & 2 \\
\hline Ocauçu & Marilia & SP & 0 & 0 & 1 & 1 \\
\hline Oswaldo Cruz & Tupã & SP & 5 & 0 & 0 & 5 \\
\hline Ourinhos & Ourinhos & SP & 3 & 0 & 0 & 3 \\
\hline Palmital & Assis & SP & 69 & 1 & 6 & 76 \\
\hline Panorama & Dracena & SP & 0 & 2 & 0 & 2 \\
\hline $\begin{array}{l}\text { Paraguaçu } \\
\text { Paulista }\end{array}$ & Assis & SP & 1 & 0 & 1 & 2 \\
\hline Parapuã & Tupã & SP & 0 & 2 & 2 & 4 \\
\hline Pedrinhas Pta. & Assis & SP & 0 & 1 & 1 & 2 \\
\hline Piacatú & Araçatuba & SP & 0 & 1 & 0 & 1 \\
\hline Piquerobi & $\begin{array}{l}\text { Presidente } \\
\text { Venceslau }\end{array}$ & SP & 1 & 0 & 0 & 1 \\
\hline Pirapozinho & \begin{tabular}{|l} 
Presidente \\
Prudente
\end{tabular} & SP & 6 & 2 & 0 & 8 \\
\hline Platina & Assis & SP & 0 & 0 & 1 & 1 \\
\hline $\begin{array}{l}\text { Presidente } \\
\text { Bernardes }\end{array}$ & \begin{tabular}{|l} 
Presidente \\
Prudente
\end{tabular} & SP & 1 & 0 & 0 & j \\
\hline \begin{tabular}{|l} 
Presidente \\
Epitácio
\end{tabular} & $\begin{array}{l}\text { Presidente } \\
\text { Venceslau }\end{array}$ & SP & 1 & 1 & 3 & \\
\hline
\end{tabular}




\begin{tabular}{|c|c|c|c|c|c|c|}
\hline $\begin{array}{|ll|}\text { Município } & \mathrm{da} \\
\text { propriedade } & \mathrm{do} \\
\text { contrato } & \mathrm{de} \\
\text { fomento } & \\
\end{array}$ & EDR & Estado & \begin{tabular}{|l|} 
Contratos \\
Vigentes
\end{tabular} & \begin{tabular}{|l|} 
Contratos \\
Vencidos
\end{tabular} & \begin{tabular}{|l|} 
Contratos \\
Desistentes
\end{tabular} & Total \\
\hline $\begin{array}{l}\begin{array}{l}\text { Presidente } \\
\text { Prudente }\end{array} \\
\end{array}$ & $\begin{array}{l}\text { Presidente } \\
\text { Prudente }\end{array}$ & $\mathrm{SP}$ & 6 & 2 & 10 & 18 \\
\hline $\begin{array}{l}\text { Presidente } \\
\text { Venceslau }\end{array}$ & $\begin{array}{l}\text { Presidente } \\
\text { Venceslau }\end{array}$ & SP & 0 & 1 & 1 & 2 \\
\hline Rancharia & Pres. Prudente & SP & 3 & 2 & 2 & 7 \\
\hline Regente Feijó & $\begin{array}{l}\text { Presidente } \\
\text { Prudente }\end{array}$ & SP & 0 & 1 & 2 & 3 \\
\hline Ribeirão do Sul & Ourinhos & $\mathrm{SP}$ & 0 & 0 & 1 & 1 \\
\hline Rosana & $\begin{array}{l}\text { Presidente } \\
\text { Venceslau } \\
\end{array}$ & SP & 4 & 0 & 0 & 4 \\
\hline Sagres & Tupã & $\mathrm{SP}$ & 1 & 0 & 0 & 1 \\
\hline Salmourão & Tupã & $\mathrm{SP}$ & 0 & 2 & 0 & 2 \\
\hline Salto Grande & Ourinhos & $\mathrm{SP}$ & 1 & 2 & 4 & 7 \\
\hline Sandovalina & $\begin{array}{l}\text { Presidente } \\
\text { Prudente }\end{array}$ & SP & 2 & 3 & 0 & 5 \\
\hline Santa Inês & - & PR & 0 & 1 & 1 & 2 \\
\hline $\begin{array}{l}\text { Santa Rita do } \\
\text { Rio Pardo }\end{array}$ & & MS & 0 & 1 & 0 & 1 \\
\hline Santo Anastácio & $\begin{array}{l}\text { Presidente } \\
\text { Venceslau }\end{array}$ & $\mathrm{SP}$ & 0 & 0 & 1 & 1 \\
\hline $\begin{array}{l}\text { Santo Antônio - } \\
\text { do Caiuá }\end{array}$ & & PR & 0 & 1 & 0 & 1 \\
\hline \begin{tabular}{|ll}
$\begin{array}{l}\text { São } \\
\text { Turvo }\end{array}$ \\
\end{tabular} & Ourinhos & SP & 1 & 0 & 1 & 2 \\
\hline Sarutaiá & Ourinhos & SP & 0 & 1 & 0 & 1 \\
\hline Sertanópolis & - & PR & 0 & 1 & 0 & 1 \\
\hline Taciba & $\begin{array}{l}\text { Presidente } \\
\text { Prudente }\end{array}$ & $\mathrm{SP}$ & 1 & 1 & 2 & 4 \\
\hline Tarabaí & \begin{tabular}{|l} 
Presidente \\
Prudente
\end{tabular} & SP & 10 & 0 & 2 & 12 \\
\hline Tarumã & Assis & SP & 5 & 1 & 0 & 6 \\
\hline $\begin{array}{l}\text { Teodoro } \\
\text { Sampaio }\end{array}$ & $\begin{array}{l}\text { Presidente } \\
\text { Venceslau } \\
\end{array}$ & SP & 1 & 9 & 10 & 20 \\
\hline Timburi & Ourinhos & SP & 1 & 0 & 0 & 1 \\
\hline Tupi Paulista & Dracena & $\mathrm{SP}$ & 1 & 0 & 0 & 1 \\
\hline TOTAL & & 4 & 274 & 119 & 143 & 536 \\
\hline
\end{tabular}

FONTE: Dados da pesquisa 
ANEXO H: Resumo das respostas fornecidas pelos proprietários com contratos de fomento florestal vigentes

\section{CONTRATOS VIGENTES}

35 propriedades responderam o formulário

1) Como ficou sabendo do programa de fomento florestal da CESP?

(29) Através da Casa da Agricultura (CATI)

(4) Foi procurado por um técnico da CESP

(1) Através de outro produtor rural

(1) Rádio; ( 1 ) Televisão

(2) Recebeu algum folheto ou material de divulgação da CESP

(0) Banco financiador

(1) Pela Prefeitura

(4) Outros

(1) Programa de Microbacias

(1) Procurou a CESP por iniciativa própria

( 1) Flora Vale (Associação de Reposição Florestal de Assis)

( 1) Não especificou

2) Por que você optou pelo plantio de árvores nativas em sua propriedade?

(27) Para cumprir a lei, sem ter sido advertido, autuado ou multado

( 0) Para cumprir a lei, depois de ter sido advertido, autuado ou multado

(1) Reserva de madeira; ( 0 ) outros produtos florestais

(5) Paisagismo da propriedade

( 5) Mudas; ( 2) assistência técnica gratuita fornecidas pela CESP

Conservação de recursos hídricos: ( 6)nascentes, (14)margens de rios ( 8)margens de represas e lagos

(9) Conservação do solo

(3) Abrigo para animais; (2) controle de pragas

( 0) Seguiu o exemplo de outras propriedades

(3) Outros

(1) Piscicultura

( 1) Conservar a margem da represa onde cultivo peixes

( 1) Proteção para o Meio Ambiente

(0) Não respondeu 
3) A mão-de-obra utilizada para a abertura das covas, plantio e manutenção foi:

(17) Familiar (família do proprietário da terra)

(11) Funcionários que já trabalhavam na propriedade

(6) Mão-de-obra contratada especialmente para este serviço

(4) Outros

(2) Ainda não plantou

(1) Funcionários da CESP

(1) Funcionários contratados pela Casa da Agricultura

( 0 ) Não respondeu

OBS: Duas propriedades utilizaram funcionários que já trabalhavam na propriedade e também contratou mão-de-obra especificamente para o plantio.

4) Você participou da escolha das espécies de árvores plantadas na sua propriedade?

(7) $\mathrm{Sim}$

(13) Não

(13) Não, mas gostaria de ter participado da escolha

( 1) gostaria de plantar mudas de ipê e muitas de árvores mais durativas

(1) ainda não plantou, nem recebeu as mudas, mas gostaria de participar da escolha

(1) ainda não plantou

5) Você rejeitou ou, caso tivesse tido a opção, rejeitaria algumas das espécies de árvores indicadas pela CESP?

(7) Sim. Quais?

(1) Angico

(2) Paineira

(1) Mudas muito pouco durativas

(1) Pau d'alho e amoreira brava

( 1) Não especificou

( 1) Várias espécies (geralmente árvores que caem)

(27) Não

(1) Plantio ainda não foi feito

6) O modelo de plantio da CESP combina o plantio de 20 a 30 espécies de árvores nativas da região. Esse plantio é organizado em linhas de plantas que crescem mais rapidamente ao lado de linhas de plantas que crescem mais devagar e que gostam de sombra. O proprietário ou algum responsável pelo plantio recebeu explicações da CESP sobre esse modelo de reflorestamento?

( 3) Não recebeu nenhuma explicação

(1) Recebeu explicação, mas não entendeu

(1) Recebeu explicação, mas não lembra

( 8) Recebeu explicação, entendeu o modelo de plantio, mas não teria condições de implantá-lo em outras áreas

(19) Recebeu explicação, entendeu o modelo de plantio, e teria condições de implantá-lo em outras áreas

( 3) Não respondeu 
7) Algumas das espécies adotadas no plantio causaram algum tipo de inconveniente:

( 1)invasão de pastagem; ( 4)invasão de área agrícola; ( 0)intoxicação de animais?

(5) Sim. Quais as espécies?

(22)Não

$$
\text { ( 5) não especificou }
$$

(5) Plantio muito novo ou ainda não plantou

(2) Não respondeu

8) Na sua propriedade foi feito algum tipo de reflorestamento sem a parceria com a CESP?

(11) Sim. Descreva-o:
(1) Eucaliptos
(1) Dia da árvore (alunos de $1^{\circ}$ grau)
( 1) DEPRN - Assis
(1) Parceria com a Casa da Agricultura
(1) Em parceria com a Flora Vale de Assis
(1) Mudas compradas na Chácara Bela Vista - Assis
(1) 500 árvores como quebra-vento (eucalipto, grevílea, etc)
( 1)Deixamos um pedaço de mata nativa na margem do rio, hoje já está formada
( 1) Recomposição de mata ciliar ao lado de um açude
( 1) Decisão própria
( 1) Não especificou

(20) Não

(4) Não respondeu

9) Como estão as margens de rios, córregos e lagos, e as nascentes presentes na sua propriedade?

(13) Estão todas protegidas por árvores

(11) Boa parte está protegida por árvores

(5) Uma pequena parte possui árvores

( 3) Não há nenhum tipo de árvore nestas áreas

(1) Se houver, afearia a área de plantio, o prejuizo é enorme, pois num rio de $2 \mathbf{m}$ de largura, $30 \mathrm{~m}$ é muito.

(1) Plantei 280 mudas

(2) Não respondeu

10) Há alguma área (capão) de mata na sua propriedade?

(9) Sim. Qual o tamanho?
(4) 1 ha
(2) 2 ha
( 1) 2,4 ha
(1) 568 ha
(1) não especificou

(21) Não

Esta mata é: (6) mata virgem ( 1) mata mexida (explorada)

(5) Não respondeu 
11) Como você avalia o programa de fomento florestal da CESP?

(9)Ótimo ( 5)Muito bom (14)Bom (3)Regular (0)Ruim ( 1)Muito ruim ( $1^{*}$ )Péssimo (2) Não respondeu

* fizeram visita, mas não plantaram

12) Marque as alternativas que você teria interesse em adotar em sua propriedade: Plantio de eucalipto: ( 4) para venda; ( 7) para uso na propriedade Plantio de espécies arbóreas nativas de valor econômico: ( 2)para venda; ( 6)para uso na propriedade

Reflorestamento de: (16)margens de rios; (10)margens de represas e lagos; (11)proteção de nascentes

( 3) Arborização de pastagem

(2) Cerca viva

(4) Quebra-vento

(3) Sistema agroflorestal (plantio consorciado de árvores e culturas agrícolas)

(12) Pomar

(7) Arborização de estradas internas

(0) Desmatar novas áreas na propriedade

(3) Outros:

(1) Nenhuma alternativa

(1) Já adotei todas as alternativas acima

( 1) Na nossa opinião, a propriedade já tem um perfil definido quanto aos itens anteriores

(6) Não respondeu

13) Você teria algum comentário a mais sobre o programa de fomento florestal da CESP?

AGRICULTOR 111,32 ha em Cândido Mota - "Não sei se os funcionários, contratados pela Casa da Agricultura, que fizeram o plantio receberam alguma explicação da CESP. Em todo caso acredito que não, pois no meu caso eles plantaram muito raso as plantas, que muitas morreram, tive que pegar meus funcionários e replantar nas covas que as mudas morreram e tive que aguar com bomba e trator com mangueira assim resistiram ao veranico que às vezes acontece em janeiro, que foi esse caso de 98 , e fazer capinagem manualmente, e no meio da rua passar um tritão".

AGRICULTOR 60,5 ha em Cândido Mota - "No meu entender o programa funciona bem pois não existe custo para o produtor adquirir as mudas e é bem orientado a sua execução. Só é lamentável que o órgão regulamentador (DEPRN) de áreas de piscicultura não aceita o plantio destas mudas, obrigando os piscicultores a recolher taxa, o que onera os custos de implantação".

AGRICULTOR 19,36 ha em Cândido Mota - "Sem muito comentários, apenas dizer que é de suma importância a presença da mata ciliar para a proteção dos mananciais de água. Estamos cuidando das árvores plantadas e nossa mata ciliar logo estará formada". 
PROFISSÃO NÃO INDICADA 12,1 ha em Cândido Mota - "Precisariam maiores orientações, mais assistência técnica na conservação das árvores plantadas".

AGRICULTOR 116,16 ha em Cândido Mota - "Deveria todas os agricultores reflorestar as margens dos rios para proteger seus rios em 50 metros".

AGRICULTOR 9,68 ha em Palmital - "A exigência da Lei (metros do córrego) toma muita área agricultável e de alto valor. A distância poderá ser diminuída sem prejudicar o programa".

AGRICULTOR 24 ha em Palmital - "Preciso que a CESP melhore mais o sistema de distribuição de mudas e fiscalização nas áreas. Fornecendo mais espécies de madeira nobre resistente na região e uma físcalização melhor do IBAMA sobre a invasão de caçadores criminosos de animais silvestres.

AGRICULTOR 9,68 ha em Palmital - "Viveiro no município de reflorestamento; iscas para controle de formiga, bem como treinamento para o controle; técnico específico para a região (acompanhamento); mais reuniões; calcareo para correção de covas e NPK; Roundup para controle de ervas daninhas, no início da formação das árvores".

DO LAR 1,5 ha em Assis - "Tenho uma área de mais ou menos 3.000 metros quadrados que tô usando para plantio de horta. Hoje gostaria de fazer tanques para criame de peixes, não para comércio (venda), somente para uso próprio, mas tenho certa dificuldade devido custo da hora da máquina. Gostaria de uma visita para me ajudar de que maneira poderia desfrutar dessa área sem dar prejuízo para o rio ou problema com o IBAMA (esta propriedade fica na divisa da cidade e área rural. Mais ou menos 1.500 metros do centro da cidade)".

EMPRESÁRIO 80,72 ha em Tarumã - "É um Programa muito bom, pois além de fornecer mudas é também fornecido o sistema de reflorestamento a ser feito na mata ciliar".

AGRICULTOR 16,94 ha em Pedrinhas Paulista - "Possuo uma propriedade no município de Pedrinhas Paulista, margeando com a represa de capivara (CESP) aonde já preparei a terra e plantei 650 mudas de grevilhas, comprada em Paraguaçú Paulista por mim, e me faltam mais de 1.000 mudas para plantar e não tenho condições de comprar, pois vivo de aposentadoria. Peço o favor para me arrumar estas mudas para mim e eu irei buscar com minha camioneta seja o lugar que for ou envie as mudas para a minha propriedade. Prefiro mudas de árvores floríferas e madeiras nobres, se for possível com urgência. Desde já antecipo meus agradecimentos e espero a sua compreensão de me ajudar com as mudas".

CIA. AGRÍCOLA várias propriedades com 20.000 ha em Tarumã - "No momento (28/10/98) estamos sem mudas para o plantio".

AGRICULTOR 68 ha em Florínea - "Plantar somente o necessário em nossa região, pois é uma região de terras férteis e produtivas".

AGRICULTOR 250 ha em Florínea - "Eu queria acrescentar que poderia haver um trabalho a ser feito de conscientização aos produtores que obtêm. rios, lagos, córregos. em suas propriedades, da 
importância de fazer o reflorestamento sobre as margens, e não somente dizer que precisa plantar. Nós agricultores faríamos até com mais vontade, se pela parte intendida do meio ambiente, com sua capacidade de estudo, pudessem transmitir para o Homem do campo a necessidade do reflorestamento, ao invés de dizer, por parte, do promotor e curador do meio ambiente, e a polícia Florestal, que tem que reflorestar os 30 metros, ou se não será autuado".

AGRICULTOR 41,14 ha em Florínea - "Quanto a CESP não sei, mas órgãos demais chegam multando, ofendendo, sem que a gente saiba de nada, chegam aplicando a multa sem os mesmos sermos avisados. Devíamos ter um pouco mais de diálogo, mas não é assim. Por serem da Lei, acham que podem fazer o que bem entendem, sem a mínima chance pra gente. Isto revolta!".

\section{ATENÇÃO}

1 não respondeu o formulário (propriedade foi arrendada para outra pessoa que não se comunica com o proprietário)

2 Não responderam as questões que estavam no verso do formulário 
ANEXO I: Resumo das respostas fornecidas pelos proprietários com contratos de fomento florestal vencidos

\section{CONTRATOS VENCIDOS}

6 propriedades responderam o formulário

1) Como ficou sabendo do programa de fomento florestal da CESP?

(2) Através da Casa da Agricultura (CATI)

(0) Foi procurado por um técnico da CESP

(1) Através de outro produtor rural

( 0) Rádio; ( 0 ) Televisão

(1) Recebeu algum folheto ou material de divulgação da CESP

(0) Banco financiador

(0) Pela Prefeitura

(2) Outros:

(1) Horto Florestal de Assis

(1) Conversa informal com o técnico da CESP

2) Por que você optou pelo plantio de árvores nativas em sua propriedade?

(1) Para cumprir a lei, sem ter sido advertido, autuado ou multado

( 0) Para cumprir a lei, depois de ter sido advertido, autuado ou multado

(0) Reserva de madeira: $(0)$ outros produtos florestais

( 0) Paisagismo da propriedade

( 0) Mudas; ( 0) assistência téenica gratuita fornecidas pela CESP

Conservação de recursos hídricos: ( 1)nascentes, ( 3)margens de rios ( 1)margens de represas e lagos

(2) Conservação do solo

(1) Abrigo para animais; ( 1 ) controle de pragas

( 0 ) Seguiu o exemplo de outras propriedades

(0) Outros

( 0 ) Não respondeu

3) A mão-de-obra utilizada para a abertura das covas, plantio e manutenção foi:

(2) Familiar (família do proprietário da terra)

(4) Funcionários que já trabalhavam na propriedade

( 0) Mão-de-obra contratada especialmente para este serviço

(0) Outros 
4) Você participou da escolha das espécies de árvores plantadas na sua propriedade?

(0) $\mathrm{Sim}$

(5) Não

( 1) Não, mas gostaria de ter participado da escolha

5) Você rejeitou ou, caso tivesse tido a opção, rejeitaria algumas das espécies de árvores indicadas pela CESP?

(1) Sim. Quais?

(5) Não

( 1) Mogno e cerejeira

( 1) as árvores da CESP eram muito bonitas

6) O modelo de plantio da CESP combina o plantio de 20 a 30 espécies de árvores nativas da região. Esse plantio é organizado em linhas de plantas que crescem mais rapidamente ao lado de linhas de plantas que crescem mais devagar e que gostam de sombra. O proprietário ou algum responsável pelo plantio recebeu explicações da CESP sobre esse modelo de reflorestamento?

(1) Não recebeu nenhuma explicação OBS: Embora constasse no projeto

(0) Recebeu explicação, mas não entendeu

(0) Recebeu explicação, mas não lembra

(1) Recebeu explicação, entendeu o modelo de plantio, mas não teria condições de implantá-lo em outras áreas

( 3) Recebeu explicação, entendeu o modelo de plantio, e teria condições de implantá-lo em outras áreas

(1) Não respondeu

7) Algumas das espécies adotadas no plantio causaram algum tipo de inconveniente:

( 1)invasão de pastagem; ( 1 )invasão de área agrícola; ( 0)intoxicação de animais?

(1) Sim. Quais as espécies?

(5)Não

(1) Sangra d'água e candiuva

8) Na sua propriedade foi feito algum tipo de reflorestamento sem a parceria com a CESP?

(4) Sim. Descreva-o:

(1) Apícolas

(2) Eucalipto

(1) Projeto REPEMIR, Prefeitura de Florínea e Flora Vale - todos com incentivo

(muda gratuita e assistência técnica

(2) Não

9) Como estão as margens de rios, córregos e lagos, e as nascentes presentes na sua propriedade?

(3) Estão todas protegidas por árvores

(2) Boa parte está protegida por árvores

(1) Uma pequena parte possui árvores

(0) Não há nenhum tipo de árvore nestas áreas 
10) Há alguma área (capão) de mata na sua propriedade?

(3) Sim. Qual o tamanho?
( 1) 0,60 ha
( 1) 1,5 ha
(1) 2,5 ha

Esta mata é: ( 1) mata virgem ( 1) mata mexida (explorada), Sofreu queimada involuntária ( 1 ) não especificou

( 3) Não

11) Como você avalia o programa de fomento florestal da CESP?

(2)Ótimo (2)Muito bom (1)Bom (0)Regular (0)Ruim (0)Muito ruim (0)Péssimo (1) Não respondeu

12) Marque as alternativas que você teria interesse em adotar em sua propriedade:

Plantio de eucalipto: ( 2) para venda; ( 1 ) para uso na propriedade

Plantio de espécies arbóreas nativas de valor econômico: ( 0$)$ para venda; ( 0 )para uso na propriedade

Reflorestamento de: ( 2)margens de rios; ( 2)margens de represas e lagos; ( 3)proteção de nascentes

(2) Arborização de pastagem

(1) Cerca viva

(0) Quebra-vento

(0) Sistema agroflorestal (plantio consorciado de árvores e culturas agrícolas)

(1) Pomar

(1) Arborização de estradas internas

(0) Desmatar novas áreas na propriedade

( 0) Outros

( 1) Não respondeu

13) Você teria algum comentário a mais sobre o programa de fomento florestal da CESP?

ENG. AGRÔNOMO 240 ha em Florínea - "O plantio iniciou-se em 1989 e quase 10 anos depois o reflorestamento apresenta-se com um vigor impressionante. Graças à boa qualidade das mudas a \% de falha foi inexpressiva. É um programa bom e eficiente, no entanto é desejável uma assistência técnica mais intensiva".

ECONOMISTA 73 ha em Pedrinhas Paulista - "O Programa da CESP era bom. A orientação foi fraca. Fiz duas etapas. Depois foi dificil pegar mudas e optei por pegar 
mudas aqui perto em Assis. As mudas que peguei na CESP eram boas e teria gostado de continuar a pegar para acabar a margem da represa - faltam ainda $2 \mathrm{~km}$ ".

USINA 2258 ha em Maracaí - "O Programa é muito interessante e deveria ser melhor divulgado, pois pequenos proprietários poderiam usá-lo para cumprirem a determinação de formação de mata ciliar em suas propriedades, e proteção de nascentes".

PROFISSÃO NÃO INDICADA 14,52 ha em Florínea - "Deveriam fornecer árvores frutiferas". 
ANEXO J: Resumo das respostas fornecidas pelos proprietários que desistiram do contrato de fomento florestal com a CESP

\section{CONTRATOS DESISTENTES}

9 propriedades responderam o formulário e uma outra enviou apenas uma carta no lugar do formulário

1) Como ficou sabendo do programa de fomento florestal da CESP?

(3) Através da Casa da Agricultura (CATI)

(1) Foi procurado por um técnico da CESP

(1) Através de outro produtor rural

( 0) Rádio; ( 0 ) Televisão

(1) Recebeu algum folheto ou material de divulgação da CESP

( 0) Banco financiador

(0) Pela Prefeitura

(4) Outros

(1) Técnicos da CESP - Setor de Hidrobiologia de Salto Grande-SP

(2) Foi procurar saber, pois queria reflorestar a margem do rio

(1) Aqui não esteve ninguém da CESP; foi o pessoal do DEPRN em uma reunião com a

Polícia Militar Florestal que comecei a me inteirar dos fatos

2) Por que plantar árvores nativas em sua propriedade?

(3) Para cumprir a lei, sem ter sido advertido. autuado, ou multado

( 0) Para cumprir a lei, depois de ter sido advertido, autuado, ou multado

(0) Reserva de madeira; ( 0 ) outros produtos florestais

(2) Paisagismo da propriedade

( 1) Mudas; ( 0) assistência técnica gratuita fornecidas pela CESP

Conservação de recursos hídricos: ( 5)nascentes, ( 7)margens de rios (4)margens de represas e lagos

(4) Conservação do solo

( 5) Abrigo para animais; ( 0) controle de pragas

( 0 ) Seguiu o exemplo de outras propriedades

(3) Outros

(1) Eucalipto

(1) gosto de plantar árvores

(1) na região há pouquíssimas áreas reflorestadas 
3) Por que você desistiu de participar do Programa de Fomento Florestal da CESP?

(2) Não concordou com os termos do contrato de cooperação entre a CESP e o proprietário

(0) Não gostou da conversa com o técnico da CESP que fez a visita a propriedade

Custos: ( 0) plantio; ( 1 ) manutenção, muito elevados para o proprietário

Demora da CESP para: ( 1 )fazer a visita; (0)assinar o contrato de cooperação

Não concordou com o modelo de plantio indicado pela CESP: (1)espaçamento; ( 0)disposição das mudas; ( 0)espécies arbóreas

Falta de: ( 1) tempo; ( 1) mão-de-obra, para o plantio e manutenção

(6) Outros

(1) Dificuldades administrativas, pois tem outra profissão e não mora no local

(1) Não tinha como buscar as mudas

(1) Custo para buscar as mudas em Porto Primavera $(300 \mathrm{~km})$

(2) Visitaram a propriedade há 4 anos atrás e nunca se manifestaram a mandar as mudas

( 1) Os custos deveriam ser custeados pelo Estado, já que caros, além disso são as

melhores terras

4) Na sua propriedade foi feito algum tipo de reflorestamento sem a parceria com a CESP?

(6) Sim. Descreva-o:

(1) Mata ciliar com mudas compradas

(2) 200 mudas na beira do rio doadas pelo Horto Florestal

(1) Já tem nativo

(1) ganhou do Horto Florestal de Assis e comprou outras

( 1) Eu não tive contato com a CESP. Em uma das áreas fiz um pequeno reflorestamento com Eucalipto na encosta

(3) Não

5) Como estão as margens de rios, córregos e lagos, e as nascentes presentes na sua propriedade?

(2) Estão todas protegidas por árvores

(3) Boa parte está protegida por árvores

(4) Uma pequena parte possui árvores

(0) Não há nenhum tipo de árvore nestas áreas

( 1) OBS: Acho que os agricultores não podem arcar com este custo sozinhos, pois as grandes cidades são as que mais poluem o ambiente

6) Há algum área (capão) de mata na sua propriedade?

(5) Sim. Qual o tamanho?

(2) 2,42 ha

(1) 3 ha

(1) 7 ha

(1) Não especificou

Esta mata é: (2) mata virgem ( 3 ) mata mexida (explorada)

(4) Não 
7) Após ter desistido deste contrato de cooperação com a CESP, você fez outro contrato?

(0) Sim, mas voltei a desistir

(0) Sim, e ainda estou fazendo o plantio

(1) Sim, e já terminei o plantio (novo contrato feito no nome da mãe)

(5) Não

(2) Quem desistiu foi a CESP, que não nos procurou mais

( 1) Eu fiz um pedido de mudas para a CESP para plantar nas encostas, através da Casa da Agricultura e ainda não obtive nem resposta

8) Você teria interesse em conversar novamente com a CESP para participar do Programa de Fomento Florestal da Companhia?

(5) $\mathrm{Sim}$

(2) Não

(1) Desde que a CESP ou o próprio Estado dessem ajuda de custo

(1) Gostaria de saber se eucalipto serve para reflorestamento

( 1) Não respondeu

9) Como você avalia o programa de fomento florestal da CESP?

(0)Ótimo ( 1)Muito bom ( 2)Bom ( 1)Regular ( 0)Ruim ( 0)Muito ruim ( 2)Péssimo ( 1) não respondeu (2) Não tenho conhecimento

10) Marque as alternativas que você teria interesse em adotar em sua propriedade Plantio de eucalipto: ( 1) para venda; ( 0) para uso na propriedade

Plantio de espécies arbóreas nativas de valor econômico: ( 0)para venda; ( 0)para uso na propriedade

Reflorestamento de: ( 3)margens de rios; ( 3)margens de represas e lagos; ( 4)proteção de nascentes

( 0) Arborização de pastagem

(1) Cerca viva

(1) Quebra-vento

(2) Sistema agroflorestal (plantio consorciado de árvores e culturas agrícolas)

(4) Pomar

(1) Arborização de estradas internas

(2) Desmatar novas áreas na propriedade

(1) Outros: Não conheço esse programa nem participo

( 1) Não respondeu 
11) Você teria algum comentário a mais sobre o programa de fomento florestal da CESP?

AGRICULTOR 13,31 ha em Cândido Mota - "Essas indicações são porque o DEPRN estão ixigindo junto com P.M. florestal; continuando eu o faço para cumprir a Lei, mas acho injustiça só os agricultores carregar esse fardo, pois as grandes fontes poluidoras nas grandes cidades, com suas enormes fábricas, e esgotos, as autoridades deveriam se preocupar também com as cidades, nós da agricultura estamos descaptalizados devido plano Real, com insumos nas alturas e preços dos nossos produtos lá em baixo . Não podemos pagar sozinhos o reflorestamento".

PROFISSÃO NÃO INDICADA 90,75 ha em Paraguaçu Paulista - "É um programa interessante. Porém, deve ser ampliado e facilitado para cumprir as Leis ambientais e recuperar os ecossistemas aquáticos e terrestre extremamente impactados pela ação equivocada e predatória do homem moderno".

ENG. AGRÔNOMO 200 ha em Assis - "O Programa é muito burocrático. A CESP precisa dar o exemplo reflorestando a margem da represa capivara".

COMERCIANTE 16,94 ha em Campos Novos Paulista - "A CESP só planta árvores aonde é só de interesse próprio".

PROFISSÃO NÃO INDICADA 41,14 ha em Campos Novos Paulista - "A CESP só planta árvores aonde é só de interesse próprio".

COMERCIANTE 14,52 ha em Cândido Mota - "Eu acho que é muito válido plantar árvores e reflorestar, mas deveria ser do jeito que o sitiante achar melhor, pois o que protege os rios e as nascentes são curvas de níveis. As árvores servem para proteger a natureza para quem gosta como eu, que já plantei muita árvore (mais ou menos 2.000) em meu sítio e já tenho mata quase formada. É o meu maior orgulho. Parabéns para vocês que lutam por isso".

AGRICULTOR Cândido Mota (não respondeu o formulário) - "A você muito sucesso por este Brasil amado. Concordo com o plantio de árvores que seja madeira de boa serventia como a peroba, marfim, ipê, canelãn, canelinha, pau-brasil e outras que eu conheço por aqui. Na minha propriedade eu plantei árvores de boa qualidade dos matos que tem aqui que eu conheço e outras mudas que peguei no florestal e Casa da Lavoura sem comunicar técnico algum. Não concordo com o reflorestamento às margens de rios pequenos ou corgos, as terras do vale é de boas cultura e está protegida de curva de nível, o pequeno agricultor sente-se dezenludido sem poder cultivar a beira do rio seja planta ou pasto. Se plantar árvores as beira dos rios pode acontecer com até a déca 1938 a 1940 o proprietário precisava limpar o leito do rio devido sértas doenças como maleita, febre amaréla, tifo e outras". 


\section{REFERÊNCIAS BIBLIOGRÁFICAS}

ALMEIDA, J. A . Pesquisa em Extensão Rural: um manual de metodologia. Brasília, MEC/ABEAS, 1989.

ANDREWS, C. W. Associações de Recuperação Florestal e a Questão Ambiental Regional. IN: Seminário sobre aspectos econômicos, sociais e ambientais do fomento florestal, Belo Horizonte, 1990. Anais. Viçosa, SIF: 1991, p. 51-63.

BARRoS, G. P. P.; Botelho, N. M. A.; BRAGA, G. M. Ação Pedagógica da Extensão Rural: discurso e prática. Economia Rural, Viçosa, MG, 9(3), Jul./Set., 1998.

BUDOWSKI, G. Distribution of Tropical American rain forest species in the light of successional process. Turrialba, 15(1), 40-42, 1965.

CELULOSE \& PAPEL. Fomento: uma boa idéia. Celulose \& Papel, São Paulo, 5(24):40-4. Set./Out. 1989.

CESP. Fomento Florestal: CESP e você, juntos, conservando o Meio Ambiente. Folder de divulgação. Governo do Estado de São Paulo, Secretaria de Energia, CESP. 
CESP. Guia de arborização. $3^{\mathrm{a}}$ ed. SP, 1988. 33p. (Coleção Ecossistemas Terrestres, 006).

CESP. Recomposição de Matas Nativas pela CESP. IN: Curso Recuperação de Áreas Degradadas, Curitiba, 1993. Anais. Curitiba: UFPR/FUPEF, 1993. V. 2, p. 32231 .

CESP. Espécies vegetais de ocorrência nas matas ciliares, indicadas para a alimentação dos peixes./ CESP. São Paulo. 1997, 19p. (Série Divulgação e Informação, 200).

DIESEL, V. A educação e a degradação ambiental no meio rural - uma abordagem crítica sobre a eficácia de programas educacionais na preservação da qualidade ambiental Dissertação de mestrado em Extensão Rural da Universidade Federal de Santa Maria (RS). 1988, 281p.

ENGEL, V. L. Restau ração x Recuperação: tendências e perspectivas mundiais. In: Anais do I Simpósio sobre Restauração Ecológica de Ecossistemas Naturais: Conferências. Departamento de ciências Florestais, ESALQ/USP, Piracicaba - SP. 1999.

FERNANDES, O . R. O Plano de Fomento Florestal da Cesp. In: Anais do I Encontro Brasileiro de Extensão Florestal, Piracicaba - SP. 1985.

FERRETTI, S. F.. Repensando o Sincretismo: Estudo sobre a Casa das Minas. São Paulo: EDUSP; São Luís: FAPEMA, 1995.

FERRO, S. Fomento Florestal: quando o dinheiro nasce em árvore. Silvicultura, São Paulo, 12(44):24-8. Jul./Ago. 1992. 
FREIRE, P. Extensão ou comunicação? Rio de Janeiro, Paz e Terra. 7a edição. 93p. (O Mundo, Hoje, v. 24), 1983.

GALJART, B. Difusão cultural, modernização e subdesenvolvimento. IN: Vida Rural e Mudança Social: leituras básicas de sociologia rural, Capítulo 5. Org. Oriowaldo Queda e Tamás Szmrecsányi. São Paulo, 1972, Ed. Nacional, 244p.

Informativo Agrícola - Coopermota - MICROBACIA: Curadora do meio ambiente acompanha formação de mata ciliar (reportagem). Março 96. Ano I - N. ${ }^{\circ} 140$, página 6.

IPEF. III SIMPÓSIO IPEF - Silvicultura Intensiva e o Desenvolvimento Sustentável. IPEF - Série Técnica, Piracicaba-SP, 8(24):1-89, jun. 1992.

IPEF. Convênio CESP e IPEF desenvolve método pioneiro de restauração de mata nativa. IPEF Notícias. Piracicaba-SP, 23(146):6-7, Setembro/Outubro - 1999

KAGEYAMA, P. Y. Extractive Reserves in the Brazilian Amazonia and Genetic Resources Conservation. In: X World Forestry Congress. Paris, 1991.

KAGEYAMA, P. Y. \& CESP - Equipe Técnica do Departamento de Meio Ambiente-e Recursos Naturais. Recomposiçãa da Vegetação com Espécies Arbóreas Nativas em Reservatórios de Usianas Hidrelétricas da CESP. Série Técnica IPEF, v. 8, n. 25, p. 1-43, set. 1992.

KAGEYAMA, P. Y. \& GONÇALVES, J. L. de M. Relatório de Pesquisas: Cooperação CESP - ESALQ - IPEF. Piracicaba, maio 1997. 
MAZUCHOWSKI, J. Z. Extensão Rural Aplicada a Área Florestal. Colégio Florestal de Iratí. Iratí - PR, 1991. 259 páginas.

NEVES, J. do C. O Fomento Florestal e seus Reflexos a Nível de Meio Ambiente. IN: Anais do Encontro Técnico Florestal, 6, Belo Horizonte: ABRACAVE, 1994. 186p.

PASSOS, C. A. M. Sistemas Agroflorestais com Eucalipto para uso em Programas de Fomento Florestal, na Região de Divinópolis, MG. Tese de Doutorado apresentada à UFV. Viçosa-MG, 1996.

POSEY, D. A . Manejo da Floresta Secundária, Capoeiras, Campos e Cerrados (Kaiapó). In: Suma Etnológica Brasileira: Edição atualizada do HANDBOOK OF SOUTH AMERICAN INDIANS. Darcy Ribeiro (Editor) et alii. Vol. 1 Etnobiologia. Petrópolis: Vozes; FINEP, 1986.

QUEDA, O. \& SZMRECSÁNYI, T. 1972. O papel da educação escolar e da assistência técnica. IN: Vida Rural e Mudança Social: leituras básicas de sociologia rural, Capítulo 17. Org. Oriowaldo Queda e Tamás Szmrecsányi. São Paulo, Ed. Nacional, 244p.

RIZZINI, C. T. Árvores e Madeiras Úteis do Brasil: manual de dendrologia brasileira. São Paulo, Ed. Edgard Blücher LTDA. 1990. $4^{\mathrm{a}}$ reimpressão da $2^{\mathrm{a}}$ edição. 296 páginas.

SECRETARIA DA AGRICULTURA E ABASTECIMENTO DE SÃO PAULO, Projeto LUPA - Levantamênto Censitário das Unidades de Produção Agropecuária . Informações Econ̂omicas, São Paulo, v. 27, n. 11, nov. 1997. 
SILVA, L. O . da. Recomposição de Matas Nativas Empreendida pela CESP: Evolução do Programa e Concepções Norteadoras. Dissertação de Mestrado apresentada ao Curso de Pós-graduação da Escola de Administração de Empresas de São Paulo da Fundação Getúlio Vargas. 1990.

SILVA, L. O . da. Recomposição de Matas Nativas Empreendida pela CESP: evolução do programa e concepções norteadoras. IN: Anais - $2^{o}$ Congresso Nacional sobre Essências Nativas - 29/3/92 a 3/4/92.

SOUZA, I. S. F. de. A importância do relacionamento pesquisa/extensão para a agropecuária. EMBRAPA, Cad. Dif. Tecnol., Brasilia, 5(1/3):63-76, jan./dez. 1988.

SZMRECSÁNYI, T. Pequena História da Agricultura no Brasil. Coleção Repensando a história. São Paulo, Ed. Contexto. 1990. 102 páginas.

VEIGA, J. E. da. Como transformar seu plano de trabalho em projeto de pesquisa. Apostila. $2^{\mathrm{a}}$ versão, 10-03-1995. 10 páginas.

VIANA, V. M. Manejo Integrado dos Recursos Florestais nas Reservas Extrativistas: A Questão da Extração de Madeira. Trabalho apresentado no Seminário sobre Alternativas Ecớnômicas para Reservas Extrativistas, C.N.S./I.E.A ., Rio Branco, Acre, 25-28/02/1991. 
APÊNDICE 1: Folder: Fomento Florestal

Se o seu rio está assím...

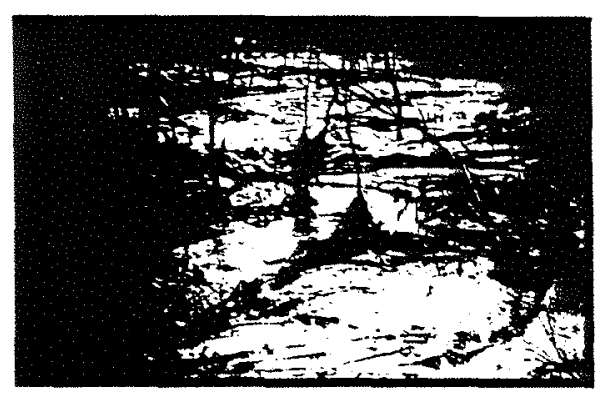

você pode recuperá-lo.

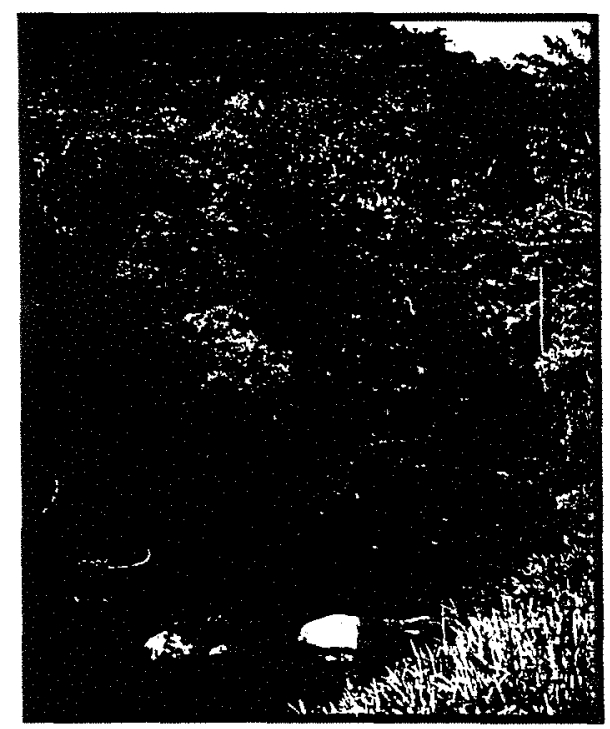

CESP Companhia Energetica de Sao Paulo Diretoria de Meio Ambiente

Endereços para correspondència:

Setor de Ecossistemas Paraná-Grande Caixa Postal 331

79601-970 - Très Lagoas - MS

Fone: (067) 521.3332

Setor de Ecossistemas Paranapanema

Viveiro de Mudas de Porto Primavera

19293-000- Primavera-SP

Fone: (018) 2841175

Setor de Ecossistemas Paraiba, Pardo e Ribeira Caixa Posta 55

12260-000 - Paraibuna - SP

Fone: (012) $3740075 \cdot 101213740491$

Setor de Ecossistemas Tieté

Rua Prefeito Dante Rochi, $\pi^{i} 1$

16370-000 - Promissáo - SP

Fone: 1014$) 5410366$ - ramal: 192

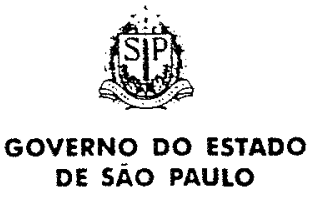

SECRETARIA

DE ENERGIA

$C \equiv S P P$

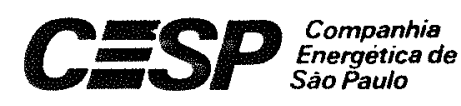

Fomento Florestal

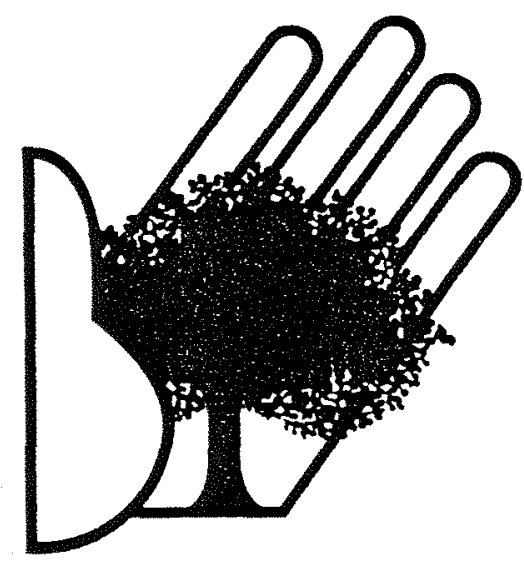

CESP e você, juntos, conservando o Meio Ambiente 


\section{O que e Programa de Fomento Florestal?}

O Programa de Fomento Florestal e uma proposta de parceria entre a CESP e proprietarios rurais e/ou empre sas, com o objetivo de recompor as matas ciliares de proteção aos seus reservatorios e as nascentes, corregos e rios que neles desaguam.

A parceria e feita atraves de um Contrato de Coope ração Reciproca em que a CESP se compromete a for necer o projeto tecnico, dotado dos mais avançados mo delos de reflorestamento. a assistència tecnica total, com tecnicos experientes e prontos para melhor orientar os parceiros, e a doaçào de mudas de essencias florestais nativas, com alta diversidade de especies (fiores, frutos madeira, importảncia ecologica etc) alem do reconhecido padráo de qualidade. Ao proprietario caberá apenas o plantio e a conducáo do refiorestamento.

Mudas de alta diversidade e qualidade e assistência técnica tota

\section{Por que a Mata Ciliar?}

A palavra "ciliar" vem de cilios, que tèm a funçào de proteger os olhos, da mesma forma que as matas prote gem as margens das nascentes e rios, garantindo a quan. tidade $e$ a qualidade da agua, entre outros beneficios

$\checkmark$ Evitar o assoreamento provocado pelas erosóes

$\checkmark$ Diminuir o risco de enchentes lou minimizar seus impactos).

$\checkmark$ Garantir o bem comum (agua) em quantidade e qualidade.

$\checkmark$ Melhorar as condiçóes para a vida aquática lpeixes outros organismos)

$\checkmark$ Proteger o solo contra a erosáo.

$\checkmark$ Oferecer abrigo e alimentaçáo à fauna

$\checkmark$ Evitar o carreamento de produtos toxicos para orio.

$\checkmark$ Contribuir no controle das pragas da lavoura, com o aumento de seus inimigos naturais.

$\checkmark$ Adequar a propriedade as determinaçoes das leis estaduais e federais (Lei $4771 / 65$ ).

\section{E ainda mais}

$\checkmark$ Condiçōes adequadas para os criterios da ISO 14000

$\checkmark$ Prevençào contra possiveis objeçoes dos orgãos fiscalizadores, quanto a garantia do uso da água.

$\checkmark$ Adequaçăo aos preceitos legais.

$\checkmark$ Melhoria da imagem junto ao publico consumidor.

$\checkmark$ Embelezamento das paisagens, para os casos de in vestimentos em turismo e lazer.

A água e um dos principais recursos para a manu tençào da vida. As açóes para preserva-ta e perpetua-la devem ser iniciativa de todos: poder publico. empresa. rios, proprietarios rurais e comunidade em geral.

\section{3 - O que a CESP tem a ver com isso?}

A preservaça dos recursos hidricos é fundamental para que a Empresa garanta a quantidade e a qualidade de sua maior "materia-prima" (águal e para assegurar a conservaçào e a viabilidade de seu parque gerador de energia.

É isso mesmo, a mata ciliar tem grande relaçào com a qualidade. quantidade e custos da energia elétrica que chega ate vocè

A CESP atua em conjunto com os demais órgáos e instituiçōes no desenvolvimento de projetos de recuperaçāo ou conservação dos Recursos Hidricos.

\section{4 - Como participar?}

Para integrar-se ao Programa, basta escrever a CESP Companhia Energenca de São Paulo informando o nome, a municipio e a localizaçảo da propriedade, com indicaça de como chegar ao local latraves de um desenho ou mapal, o nome da pessoa para contato e. se possivel, seu telefone. Depois e so aguardar a visita de um tecnico da CESP à sua propriedade.

Teremos o maior prazer em atendè-lo!
O contrato é de cooperaçâo: vocè assume o plantio es tratos culturais do reflorestamento.

O resto écom a CESP

\section{5-Algumas das espécies oferecidas:}

Araça

Guabiroba

Cambuci

Sangra d'Água

Peroba

Jequitibá

Alelueiro

Ingá

Bracatinga

Jatobá

Angico

Quaresmeira Cambará

Caiuia Figueira

Capixingui Palmito

Pau Jacaré Suinà

Saguaragi Unha de Vaca

Copaiba Olho de Cabra

Cabreuva Guapuruvu

Cedro Canela

Cedro

Bicuiba

Canela

Gerivá

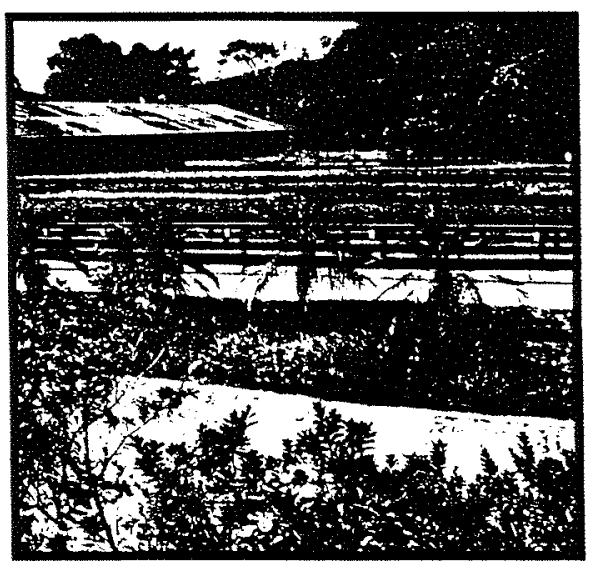

Vivairo de mudas 
APÊNDICE 2: Formulário de avaliação rápida a campo dos plantios fomentados.

\title{
Avaliação dos Plantios Fomentados pela CESP
}

\author{
André Rocha Ferretti
}

\author{
Versão 1.0 (setembro 1997)
}

Público alvo: Áreas revegetadas pelo Programa de Fomento da CESP

Objetivo: Avaliar a qualidade do plantio e o envolvimento do proprietário para com a manutenção do mesmo (levantamento rápido no campo)

Nome da Propriedade:

Nome do Proprietário:

Área revegetada:

Área de Preservação Permanente:

( ) não

( ) margem do reservatório. Largura da faixa revegetada:

( ) margem de rio. Largura do rio:

Largura da faixa revegetada:

( ) açude/lago. Diâmetro do espelho d'água:

( ) declividade $<45^{\circ}$

Largura da faixa revegetada:

( ) declividade $>45^{\circ}$

OBS:

Data/Idade do Plantio: 
1) Desenvolvimento de plantas invasoras:

( ) muito reduzido, praticamente sem plantas invasoras

( ) reduzido, sem competição com as árvores

( ) controlado, competindo sem causar prejuizos graves ao plantio

( ) avançado, competindo e causando prejuizos ao plantio

( ) muito avançado, comprometendo o plantio (morte de muitas mudas)

OBS:

2) Presença de pragas:

Tipo: ( )formiga ( )cupim ( )lagarta ( )lebre ( )outros:

( ) ausente, sem nenhum sinal

( ) reduzida, sinais pouco aparentes e sem danos às plantas

( ) controlada, presença visível e pequenos danos ao plantio

( ) alta, grandes danos comprometendo o plantio

( ) muito alta, destruindo o plantio

OBS:

3) Risco de incêndio:

3.1) Aceiro

( ) sem aceiro

( ) com aceiro: ( ) mal conservado; ( ) bem conservado

3.2) Sinais de fogo

( ) sinal de fogo, sem grandes prejuizos ao plantio

( ) sinal de incêndio, com grandes danos ao plantio

OBS:

4) Proteção da área contra a entrada de grandes animais (gado, cavalos, ...):

4.1) Presença de cerca

( ) sem cerca

( ) com cerca: ( ) bem conservada; ( ) mal conservada

4.2) Sinais de danos causados por grandes animais

( ) sem danos causados por grandes animais

( ) com danos causados por grandes animais

OBS: 
5) Periodicidade das manutenções até o $2^{\circ}$ ano (capina, aceiro, cerca, ...):
( ) até 4 meses
( ) $5-7$ meses
( ) 8-10 meses
( ) 10-12 meses
( ) mais que 12 meses

OBS:

6) Implantação do modelo proposto pela CESP:

( ) conforme recomendações

( ) alterações pouco visíveis

( ) alterações visiveis

( ) alterações significativas

( ) não seguiu as recomendações

Quais alterações?

7) Mortalidade das Pioneiras:
( ) $0-20 \%$
( ) $20-40 \%$
( ) $40-60 \%$
( ) $60-80 \%$
( ) $80-100 \%$
OBS:

8) Mortalidade das Não Pioneiras:
( ) $0-20 \%$
( ) $20-40 \%$
( ) $40-60 \%$
( ) $60-80 \%$
( ) $80-100 \%$
OBS: 
9) Crescimento das espécies Pioneiras:

( ) cresceram acima do esperado

( ) cresceram dentro do esperado

( ) cresceram um pouco abaixo do esperado

( ) cresceram muito abaixo do esperado ou não cresceram nada

( ) morreram

OBS:

10) Crescimento das espécies Não Pioneiras:

( ) cresceram acima do esperado

( ) cresceram dentro do esperado

( ) cresceram um pouco abaixo do esperado

( ) cresceram muito abaixo do esperado ou não cresceram nada

( ) morreram

OBS:

11) Uniformidade das Pioneiras plantadas:

( ) sem diferença no desenvolvimento das diferentes espécies e entre os indivíduos de cada espécie

() sem diferença no desenvolvimento das diferentes espécies e alguma diferença entre os indivíduos de cada espécie

( ) alguma diferença no desenvolvimento das diferentes espécies e sem diferença entre os indivíduos de cada espécie

( ) diferença significativa no desenvolvimento entre os individuos de cada espécie

( ) diferença significativa no desenvolvimento das diferentes espécies

12) Uniformidade das Não Pioneiras plantadas:

( ) sem diferença no desenvolvimento das diferentes espécies e entre os indivíduos de cada espécie

() sem diferença no desenvolvimento das diferentes espécies e alguma diferença entre os indivíduos de cada espécie

( ) alguma diferença no desenvolvimento das diferentes espécies e sem diferença entre os indivíduos de cada espécie

( ) diferença significativa no desenvolvimento entre os indivíduos de cada espécie

( ) diferença significativa no desenvolvimento das diferentes espécies 
13) Regeneração de espécies Pioneiras:

( ) com regeneração, manutenção da regeneração

( ) com regeneração, eliminação da regeneração

( ) com sinais de regeneração (produção de flores e/ou frutos, mudas, ...)

( ) sem regeneração

( ) sem regeneração, plantio muito jovem

OBS:

14) Regeneração de espécies Não Pioneiras:

( ) com regeneração, manutenção da regeneração

( ) com regeneração, eliminação da regeneração

( ) com sinais de regeneração (produção de flores e/ou frutos, mudas, ...)

( ) sem regeneração

( ) sem regeneração, plantio muito jovem

OBS:

15) Alinhamento do Plantio

( ) em nível, em quinquôncio

( ) em nível, mas não em quinquôncio

( ) linhas em desnível

( ) linhas retas em quinquôncio

( ) morro à baixo

OBS:

Espaçamento de plantio:

Espécies Pioneiras (sombreadoras):

Espécies Não Pioneiras (sombreadas): 
Croqui:

OBS: 
APÊNDICE 3: Questionário de entrevista aos proprietários fomentados.

\section{Questionário(Proprietários)}

André Rocha Ferretti

Versão 1.0 (setembro 1997)

Público alvo: propriedades fomentadas pela CESP

Objetivo: Levantar informações sobre a propriedade; motivações do proprietário para a revegetação; avaliação do proprietário sobre o programa de fomento da CESP.

Nome do Proprietário:

Nome da Propriedade:

Município:

Área da Propriedade:

1) Há quanto tempo a propriedade pertence a este dono?

2) Alguma atividade econômica é desenvolvida na propriedade? Qual?

3) O proprietário reside na área? Ele possui outras propriedades?

4) Quando a propriedade foi adquirida, a área que está sendo, ou foi revegetada, possuía vegetação nativa ou não? Em caso positivo, porque esta vegetação foi retirada?

5) Quais as razões que levaram o proprietário a revegetar parte de sua propriedade?

6) Como o proprietário ficou sabendo do programa de fomento da CESP e como foi o contato com a Companhia? 
7) Qual o tamanho, em hectares, da área revegetada? Quando foi feito o plantio e em quanto tempo?

8) Seria possível fazer uma descrição da área que está sendo, ou foi revegetada?

9) Quantas mudas foram fornecidas?

10) Quem escolheu as espécies que foram plantadas? O proprietário teve alguma participação?

11) Quem elaborou o modelo de plantio? O proprietário teve alguma participação?

12) O proprietário entendeu o modelo de reflorestamento da CESP? Tem alguma dúvida?

13) O proprietário ficou satisfeito com o plantio?

14) Qual o custo do projeto para o proprietário?

15) Após o plantio foi feita alguma intervenção na área plantada? Qual e por que? 
16) Quando pensou em revegetar sua propriedade, como o proprietário imaginou que seria? Há diferenças entre esta primeira idéia (do proprietário) e a floresta implantada com o auxílio da CESP?

17) Qual a avaliação que o proprietário faz do programa de fomento da CESP? Gostaria de dar alguma sugestão?

18) O proprietário pretende revegetar outras áreas nesta propriedade? Como gostaria que fosse o plantio?

19) O proprietário conhece outras propriedades que participam do programa de fomento da CESP?

20) O proprietário recomendaria o programa de fomento da CESP para outros proprietários? 
APÊNDICE 4: Questionário de entrevista aos funcionários da CESP envolvidos no

Programa de fomento florestal da empresa.

\section{Questionário(CESP)}

André Rocha Ferretti

Versão 1.0 (setembro 1997)

Público alvo: Funcionários da CESP

Objetivo: Avaliar o nível de informação dos funcionários da CESP sobre o Programa de Fomento da Companhia.

Nome do Funcionário:

Cargo/Função:

1) Há quanto tempo você está trabalhando na CESP?

2) Descreva o Programa de Fomento Florestal da CESP.

3) O seu trabalho tem alguma relação com o Plano de Fomento Florestal da CESP?

4) Como é a relação entre a CESP e os fomentados?

5) Você teria alguma sugestão para melhorar o Programa de Fomento Florestal da CESP? 
APÊNDICE 5: Ficha de cadastro da propriedade fomentada.

\title{
Ficha da Propriedade Fomentada
}

\author{
Versão 1.0 (setembro 1997)
}

André Rocha Ferretti

Público alvo: Programa de Fomento da CESP (consulta ao arquivo de dados e contrato)

Objetivo: Resgatar dados contratuais entre a CESP e o fomentado; informações sobre a propriedade e a área revegetada; e o histórico da relação entre a Companhia e o fomentado.

Nome da Propriedade:

Município:

Nome do Proprietário:

Endereço para contato:

Telefone para contato:

Área da Propriedade (ha):

Atividade Econômica da Propriedade:

Área Fomentada (ha):

Número de mudas fornecidas:

Espécies plantadas:

Descrição da área revegetada:

Custo para a CESP: 
1) Como foi feito o contato desta propriedade com a CESP?

2) Qual o motivo que levou o proprietário a revegetar a área?

3) O proprietário recebeu alguma explicação sobre o modelo de plantio e sobre as espécies plantadas?

4) O proprietário participou de alguma forma da escolha das espécies e na elaboração do modelo de plantio? Ele pediu a inclusão ou vetou alguma espécie?

5) O proprietário fez alguma reclamação após receber as mudas?

6) Foi feita alguma vistoria na área após o plantio? O plantio seguiu as recomendações da CESP? 
APÊNDICE 6: Modelo de Contrato de fomento florestal

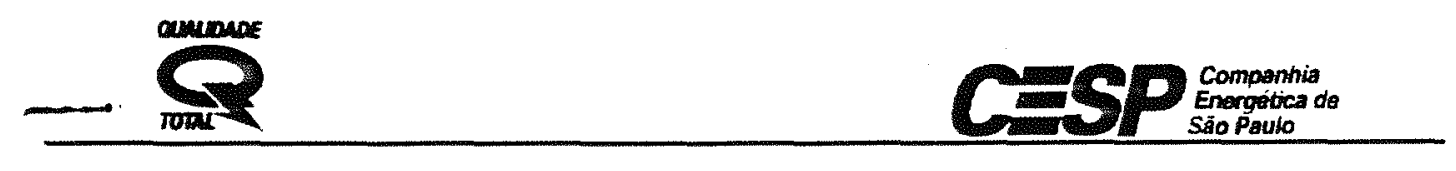

\title{
DIRETORIA DE MEIO AMBIENTE
}

DEPARTAMENTO DE IMPLANTAÇĀO AMBIENTAL

DIVISÃO DE IMPLANTAÇÃO DE PROJETOS FÍSICO-BIÓTICOS

\author{
SETOR DE ECOSSISTEMAS \\ PARANAPANEMA
}
PROGRAMA DE FOMENTO FLORESTAL
PROJETO TÉCNICO MIFP-FF-

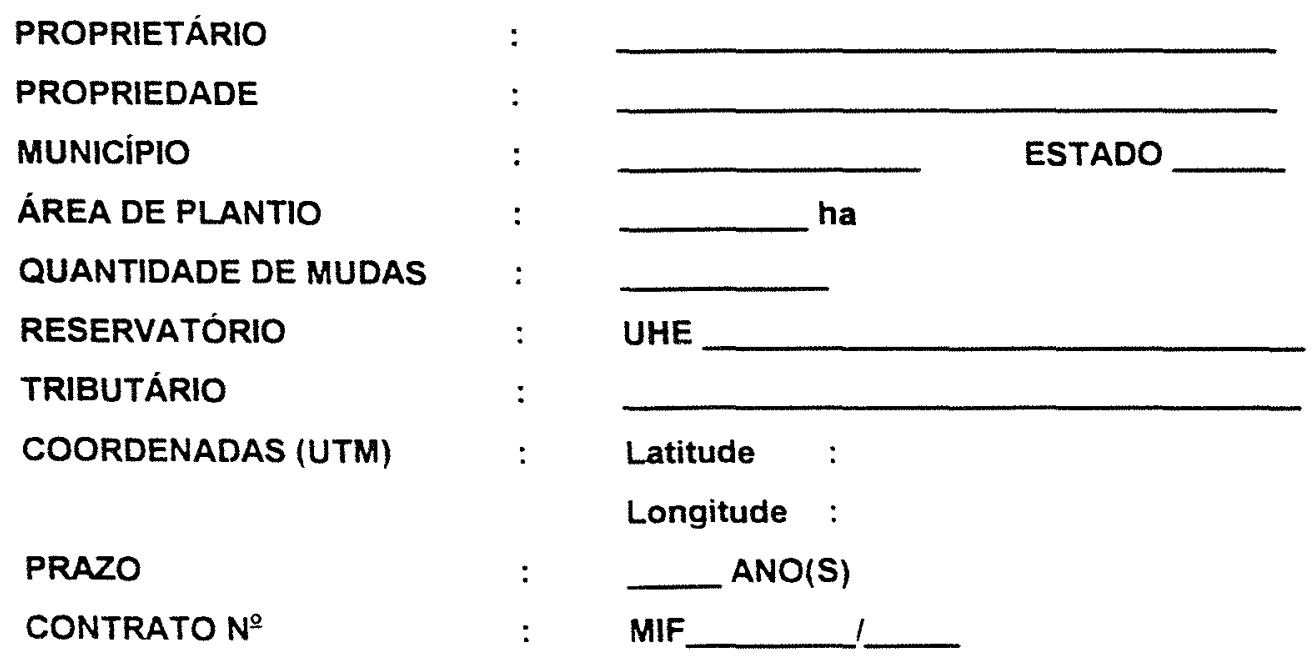


D. Companhia TOTAL- L Säo Paulo

\section{POLÍTICA DE MEIO AMBIENTE DA CESP}

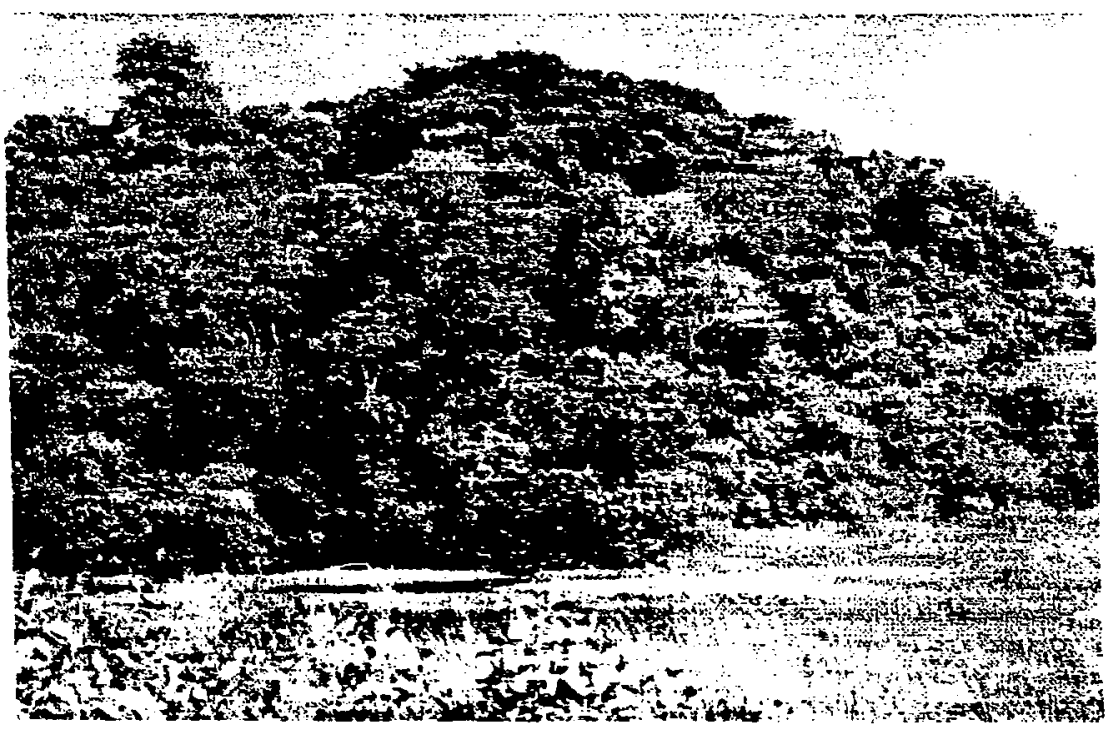

- Mata Ciliar - Rio Paranapanema

\section{Objetivos da Politica de Meio Ambiente:}

- Afirmar, em principios que regem todas as suas atividades, a responsabilidade da CESP na conservação, recuperação e proteção dos recursos do meio ambiente que utiliza ou afeta no desempenho de suas atividades.

- Definir, padronizar e implementar as diretrizes e os mecanismos que possibilitem à Empresa e a todos os seus empregados transformar essa responsabilidade em açāo.

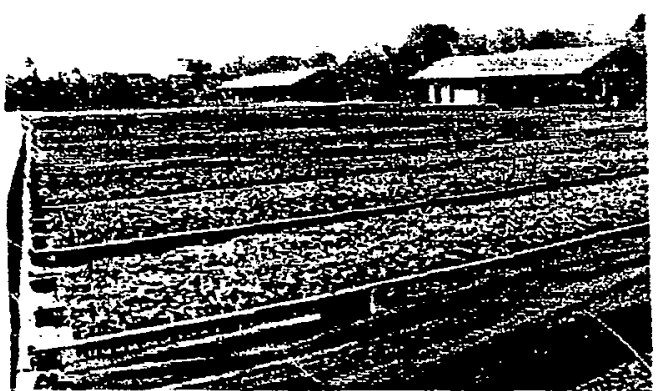

- Viveiro de Produção de Mudas Primavera, SP 


\section{DECLARAÇÃO DE PRINCÍPIOS}

A CESP identifica, avalia e considera todas as implicações ambientais de suas atividades. assumindo sua responsabilidade por estas implicaçōes.

Além de integrar as questões ambientais a seus processos decisórios, utilizando todos os meios possiveis para conservar, recuperar e proteger o meio ambiente, a Empresa considera a qualidade ambiental como um dos aspectos primordiais da busca da qualidade total.

A politica de Meio Ambiente da CESP está baseada em deciaração de princípios e nos meios para sua implementação que regulam ética e operacionalmente a atuação da Empresa e as ações do seu quadro de empregados, empreiteiros, parceiros e fornecedores.

\section{PRINCÍPIOS}

01 - Planejar, projetar e desenvolver suas atividades levando em consideração todas as implicaçōes ambientais.

02 - Considerar a bacia hidrográfica como unidade de gestão ambiental.

03 - Mitigar os impactos ambientais decorrentes de suas atividades com medidas práticas e implantação de programas de conservação, recuperação e proteção ambientais.

04 - Implementar programas de compensação por perdas ambientais, onde não cabe a mitigação. decorrentes da implantação, operação e manutenção de seus empreendimentos.

05 - Utilizar as múltiplas possibilidades de uso dos reservatórios para implantar seus programas de conservaçāo ambiental.

06 - Assegurar a participação dos individuos, grupos e organizações afetados pelos empreendimentos, já nas fases de estudo e projeto das atividades da Empresa e na implantação de programas ambientais.

07 - Estabelecer procedimentos técnicos e administrativos e adequaçōes estruturais necessários para o cumprimento das leis, regulamentos, normas e políticas de governo.

08 - Considerar a conservação de energia dependente da conservação dos recursos naturais.

09 - Integrar a qualidade ambiental à qualidade total.

10 - Envolver todos os empregados. empreiteiros. parceiros e fornecedores no mesmo compromisso com a conservação. recuperação e proteção ambientais e com a melhoria da qualidade de vida. 


\begin{tabular}{l} 
INSTRUMENTO PARTICULAR r DE \\
CONTRATO DE COOPERAÇÃO RECIPROCA \\
PARA IMPLANTAÇAOO DE PROJETO DE \\
REFLORESTAMENTO CILIAR, QUE ENTRE \\
SI CELEBRAM A CESP - COMPANHIA \\
ENERGETICA DE SÃO PAULO E \\
\hline
\end{tabular}

Por este instrumento particular, as partes, de um lado a CESP - Companhia Energética de São Paulo, sociedade anônima de Capital aberto, sediada à Alameda Ministro Rocha Azevedo $n^{\circ} 25$, nesta Capital, CGC/MF $n^{\circ}$ 60.933.603/0001-78, representada, neste ato, por

(Profissão), (Est. Civil), (Nacionalidade), residente e domiciliado à (Endereço), no (Município), (Estado), portador da (RG) e (CPF) e por (Profissão), (Est. Civil), (Nacionalidade), residente e domiciliado à (Endereço), no (Município), (Estado), portador da (RG) e (CPF), doravante designada apenas CESP e de outro lado,

(Profissão), (Est. Civil), (Nacionalidade), residente e domiciliado à (Endereço), no (Municipio), (Estado), portador da (RG) e (CPF), doravante designado apenas PROPRIETÁRIO.

Considerando que:

$1^{\circ)}$ é do interesse mútuo da CESP e do PROPRIETÁRIO o controle da erosão das terras marginais ao Córrego tributário do Rio $\overline{\mathrm{UHE}}$ afluente da margem do reservatório da

$\left.2^{\circ}\right)$ dentre os objetivos da CESP, o da conservação ambiental está intimamente relacionado com o revestimento vegetal das áreas marginais aos seus reservatórios, evitando a erosão das terras e propiciando o desenvolvimento da flora e proteção da fauna.

outorgam, a saber:

Têm entre si justo e contratado o que a seguir mutuamente aceitam e

\section{Cláusula $1^{2}$}

Constitui objeto deste instrumento e cooperação reciproca da CESP e do PROPRIETÁRIO na implantação dos projetos de reflorestamento ciliar nas áreas marginais ao reservatório da UHE de propriedade do PROPRIETÁRIO, compreendendo:

a) ha de terras da faixa de segurança de propriedade do PROPRIETÁRIO, neste instrumento identificada apenas como faixa de proteção e de preservação permanente. 
Cláusula 2a

A implantação do projeto de reflorestamento ciliar atenderá as normas e especificações determinadas pela CESP e, em especial, o contido no ANEXO I (Projeto Técnico MIFPS-FF), devidamente rubricado pelas partes.

\section{Cláusula 3a}

Na consecução do objeto ora contratado caberá ao PROPRIETÁRIO a execução do Projeto de reflorestamento, comprometendo-se a:

3.1 fornecer e responder pela mão-de-obra não qualificada necessária á execução dos projetos de reflorestamento, bem como os instrumentos adequados ao plantio e manutenção do reflorestamento, na faixa de proteção;

3.2 zelar e proteger as áreas reflorestadas, evitar a ocupação e utilização por terceiros alheios à presente contratação;

3.3 atender ás orientaçōes e determinações dos técnicos da CESP na execução do reflorestamento e das normas relativas aos aspectos de proteção.

\section{Cláusula $4^{a}$}

Na consecuçāo do objeto contratado caberá à CESP a elaboração, orientação técnica e acompanhamento de projeto de reflorestamento, comprometendo-se mais a:

4.1 fornecer, por sua exclusiva conta, as mudas das essências florestais necessárias á implantação do projeto de reflorestamento, na faixa de proteção;

4.2 atender, sempre que necessário, ás solicitações do PROPRIETÁRIO relacionadas com a técnica da execução do projeto de refiorestamento.

\section{Cláusula 5a}

$\mathrm{Na}$ implantação do projeto de reflorestamento ora contratado, cada parte assumirá integral e exclusivamente todos os custos, financeiros, fiscais, trabaihistas, previdenciários, administrativos, comerciais e quaisquer outros ocorridos ou a ocorrerem, de acordo com a sua respectiva competência, conforme contido nas cláusulas $3^{a}$ e $4^{a}$ deste instrumento, sem transferirem uma a outra, ônus seja de que natureza forem.

\section{Cláusula 6a}

Fica vedada expressamente a exploração da faixa de proteção e de preservaçāo permanente, comprometendo-se ás partes a observar fielmente o ora pactuado, respondendo a parte inadimplente pelas sançōes legais daí decorrentes. 
Cláusula 7a

Na elaboração do projeto florestal da faixa de proteção a CESP observará a técnica adequada aos padrões existentes e preceitos legais aplicáveis, respondendo, integral e exclusivamente, pela sua inobservância.

\section{Cláusula 8*}

$\mathrm{Na}$ execução do projeto florestal da faixa de proteção, PROPRIETÁRIO observará as normas e especificações técnicas recomendadas pela CESP, respondendo integral e exclusivamente pela sua inobservancia.

\section{Cláusula 9a}

A responsabilidade civil do projeto ora contratado está limitada às atividades exercidas respectivamente pelas partes de acordo com as suas competências e obrigações estabelecidas nas cláusulas $3^{a}$ e $4^{a}$ deste instrumento, estando cada uma isenta de responsabilidade e ressarcimento decorrentes de atividades que não sejam de sua exclusiva competência.

\section{Cláusula 10"}

O presente contrato tem prazo de 04 (Quatro) anos de duraçăo, contados a partir da data da sua assinatura.

\section{Cláusula 11*}

O presente instrumento poderá ser rescindido a qualquer tempo por consenso entre as contratantes ou denunciado unilateralmente, sem incidência de ônus, mediante comunicaçāo prévia por escrito de 120 (cento e vinte) dias.

\section{Cláusula 12a}

As disposiçōes ora pactuadas poderão ser alteradas mediante consenso prévio das contratantes e formalização de instrumento de aditivos a este.

\section{Cláusula 13*}

estimado de R\$

Dão as partes, de comum acordo, ao presente instrumento o valor total

\section{Cláusula 14*} constitui novação.

A tolerância das partes, no cumprimento das obrigaçōes ora assumidas, não

\section{Cláusula 15}

O presente instrumento vigora a partir da data da sua assinatura. 
Cláusula 16ª

4

Elegem as partes de comum acordo o Fórum da Comarca da Capital do Estado de São Paulo, distrito da Sé, como o competente para solucionar as questões oriundas do presente instrumento, com renúncia expressa a qualquer outro por mais privilegiado que seja.

E por estarem assim acordes, assinam o presente instrumento em 03 (Três) vias de igual teor e forma, com as 02 (Duas) testemunhas abaixo, a tudo presentes. 
Säo Paulo, de de

Pela CESP - Companhia Energética de Sāo Paulo:

PElO PROPRIETÁRIO:

(Nome do Proprietário)

Testemunhas:

$1^{\circ}$

Nome:

End.:

$2^{\circ}$

Nome:

Mun.:

End.:

RG.:

RG. :

ULTIMA FOLHA DO INSTRUMENTO PARTICULAR DE CONTRATO DE COOPERAÇÃO CIPROCA PARA IMPLANTACAOO DE PROJETO DE REFLORESTAMENTO CILIAR, QUE ENTRE SI CELEBRAM A CESP - COMPANHIA ENERGÉTICA DE SÃO PAULO E 


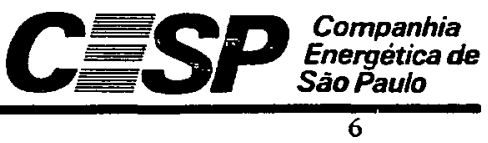

ANEXO I. PROJETO TÉCNICO MIFPS-FF.

1. TÍTULO:

Implantação de Reflorestamento Ciliar à margem do Córrego

afluente da margem $\_$tributário do Rio do município de

2. INTRODUÇÃO:

Este projeto visa fornecer subsidios técnicos para implantação e manutenção de reflorestamento ciliar.

3. OBJETIVO:

Recomposição da vegetação em áreas marginais aos reservatórios e tributários, propiciando a conservação de solos e controle de erosāo, desenvolvimento da flora e proteçāo da fauna.

4. LOCAL:

Córrego_, tributário do Rio margem do

5. ABRANGÊNCIA:

Implantação de reflorestamento ciliar com espécies nativas, no espaçamento $2 \times 2,5 \mathrm{~m}$, (modelo quincôncio) em uma área de ha, totalizando mudas.

Obs: Caso sejam necessárias, as operaçōes mecanizadas deverão ser autorizadas pelo DEPRN - Departamento Estadual de Proteção dos Recursos Naturais.

6. IMPLANTAÇÃO: De acordo com o esquema de plantio. obedecendo o sistema de sucessão secundária (Figura 1) e Cronograma de Implantação de Operaçōes Técnicas, anexo.

\section{OPERAÇŌES TÉCNICAS:}

\subsection{Roçada manual prévia}

Deve ser conduzida com foice ou ferramentas similares, assegurando o corte da vegetação o mais rente possivel do solo, evitando causar danos ao sistema radicular.

Nessa operação deverão ser poupadas as espécies arbustivas e arbóreas.

7.2. Combate a formigas

Deverá ser feita uma vistoria geral na área de plantio e adjacências, para localizar e combater os formigueiros com 0 uso de formicida adequado, conforme orientação de profissional habilitado.

Esta operação deverá ser repetida quando necessário.

7.3. Marcação de covas

Essa operação consiste na determinação do pontos onde deverão ser abertas as covas. As linhas de plantio deverão ser alinhadas paralelamente às curvas de nivel. As covas deverão ser alternadas (sistema de quincôncio), conforme Figura 1. 
7.4. Coroamento para plantio

Para evitar-se a competição aérea e radicular entre ervas invasoras e mudas, devera ser realizado o coroamento ao redor das covas, com um raio minimo de $60 \mathrm{~cm}$ a partir das bordas de cada cova, com o uso de enxada ou ferramenta similar.

\subsection{Coveamento manual}

Esta operação consiste na abertura de covas com a utilizaçăo de enxadão ou cavadeira, nos locais previamente determinados. As covas serão abertas com as medidas horizontais de $20 \times 20 \mathrm{~cm}$, e $25 \mathrm{~cm}$ de profundidade aproximada. Após a adubação, descrita no item 7.6, as covas deverão ser fechadas. A seguir, no centro da cova, deverá ser reaberto um orificio com as dimensōes do tubete.

\subsection{Adubaçåo na cova}

Consiste na aplicação de corretivos e fertilizantes, conforme determinaçōes baseadas na análise de solos. Os corretivos e fertilizantes aplicados na cova deverão ser incorporados à todo o volume de terra retirado da mesma. Para tanto. os fertilizantes deverāo ser colocados sobre o montículo de terra oriundo da abertura da cova e, com auxilio de enxada, misturados até obter-se uma mistura uniforme.

\subsection{Plantio florestal}

Após retirar a muda do tubete, essa deve plantada na cova, aprumando-a e compactando manualmente o solo ao seu redor, de modo a evitar danos às raizes.

O colo da muda deve ficar em concordância com a superficie do terreno, ficando o substrato original recoberto por uma leve camada de terra.

Se houver excesso de terra retirada da cova, agora ocupada pela muda, esse deve ser disposto em coroa ao redor da muda, com um raio minimo de $60 \mathrm{~cm}$, para assegurar um melhor armazenamento de água.

7.8. Irrigação

Essa operação consiste na distribuição de 05 (cinco) litros de água por planta após o plantio ou quando as folnas das mudas começarem a apresentar-se murchas.

7.9. Replantio florestal

Após 40 (quarenta) dias do plantio, a área deverá ser vistoriada, localizando-se as covas das mudas que não sobreviveram. Nessas covas deverão ser repetidas todas operaçōes de plantio, exceto a adubação na cova.

7.10. Roçada manual de manutençăo

Deve ser conduzida com foice ou ferramentas similares, assegurando o corte da vegetação o mais rente possivel do solo, tomando-se cuidados para evitar danos às mudas. Essa operaçăo será realizada somente nas entrelinhas de plantio.

\subsection{Capina manual em coroa}

Com o uso de enxadas ou ferramentas similares, eliminar as ervas invasoras existentes dentro das coroas de plantio, conservando um raio minimo de $60 \mathrm{~cm}$. Nessa operaçāo devem ser tomados todos os cuidados para se evitar danos ao sistema radicular superficial das mudas. 
7.12. Adubação localizada em cobertura

A adubação de cobertura deverá seguir as recomendaçōes técnicas baseadas na análise de solo.

Ao redor de cada muda plantada deve ser aberto um sulco com enxada, a uma profundidade de $10 \mathrm{~cm}$ e distancia mínima de $20 \mathrm{~cm}$ entre o sulco e a muda. Após a distribuição do fertilizante nesse sulco, o mesmo deverá ser incorporado ao solo. 


\section{AUTORIA}

\section{PROJETO E ASSISTÉNCIA TÉCNICA:}

CESP - Companhia Energética de São Paulo

Viveiro de Produção de Mudas

UHE Porto Primavera

Av. dos Barrageiros sin.

19274000 - PRIMAVERA, SP

Telefax: (018) 284-1175 
Seção de Silvicultura de Primavera

Programa de Fomento Florestal

\section{Cronograma de Implantação de Operações Técnicas.}

MIFPS-FF-

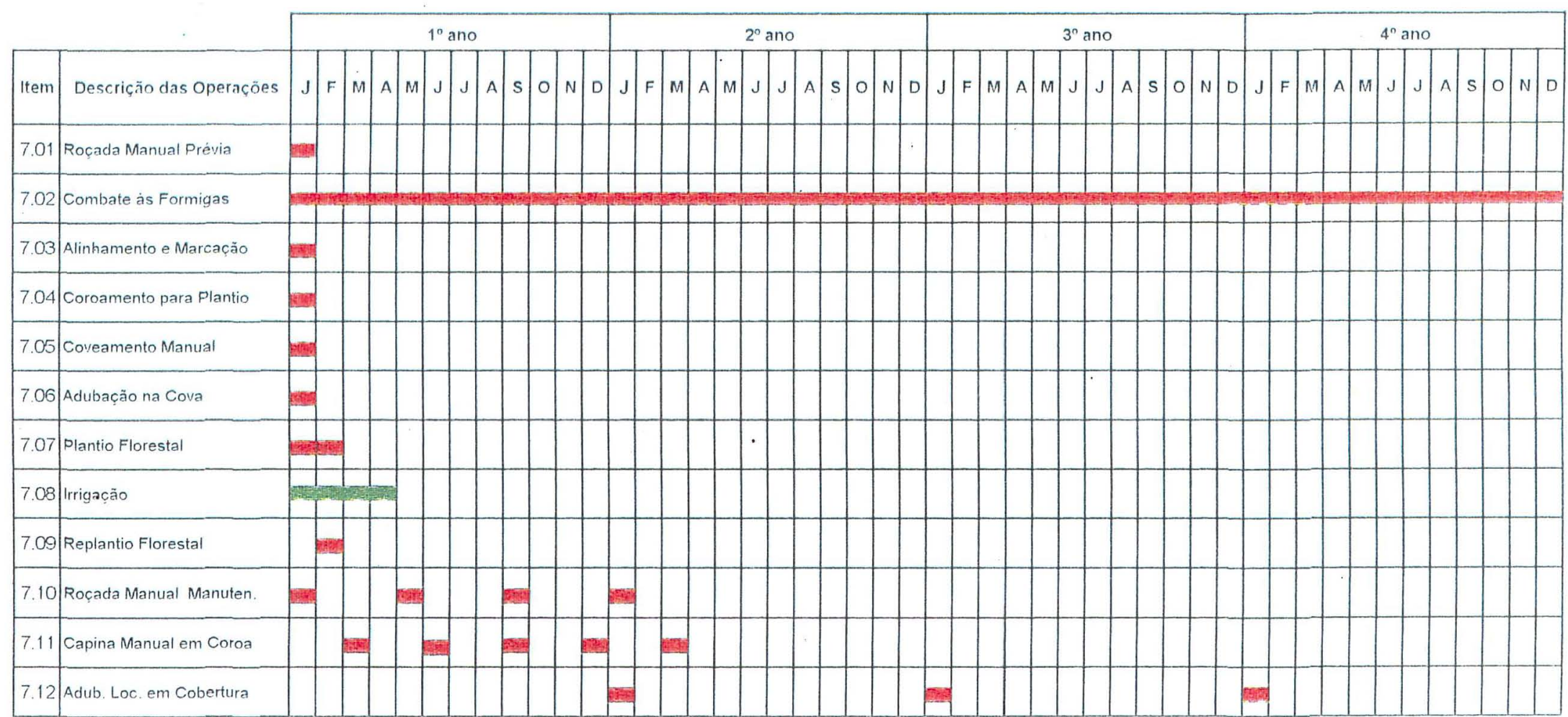




\section{Figura 01. Esquema de Plantio}

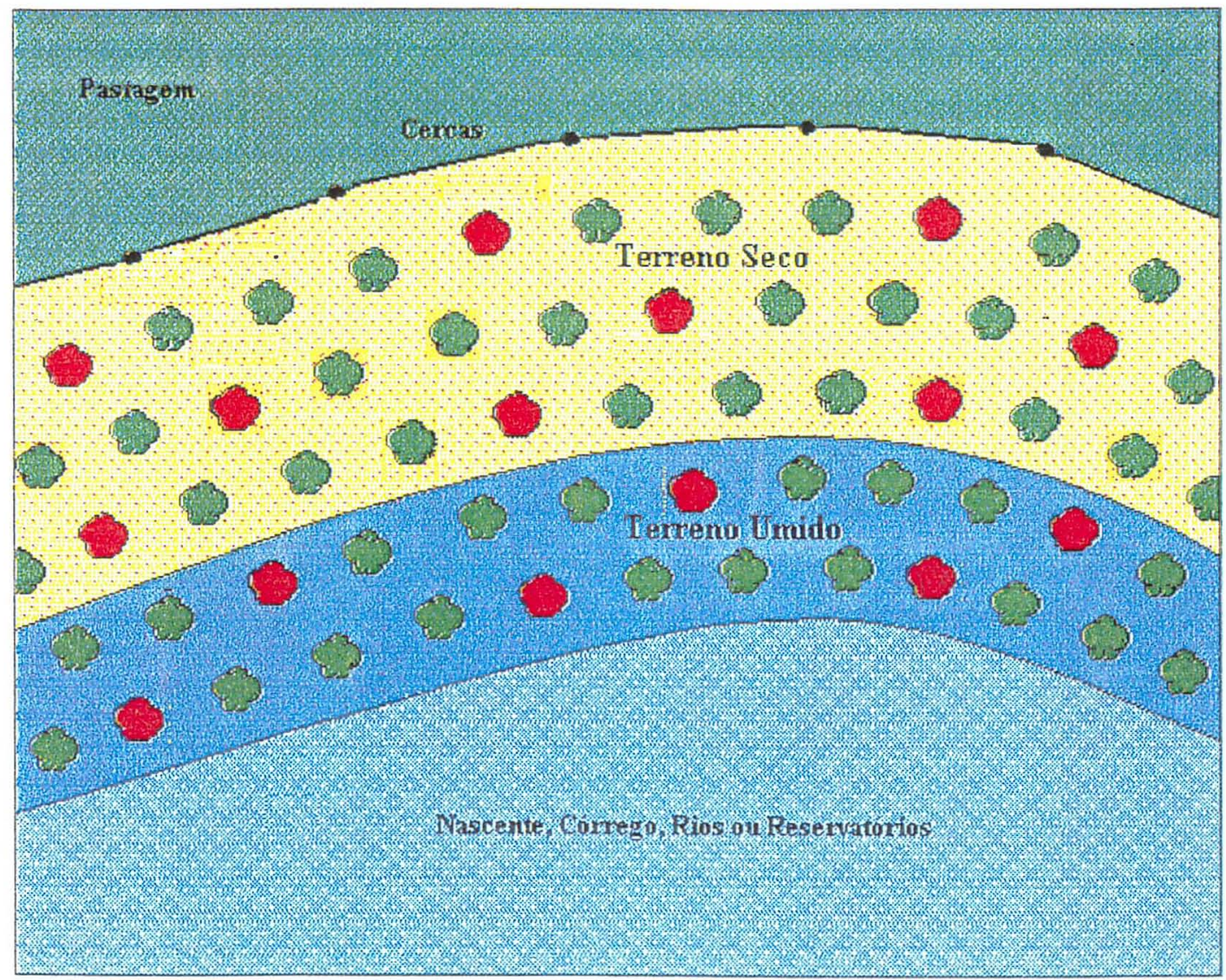

Espaçarmento: 2,0 th eritre Plantas

$2,5 \mathrm{~m}$ entre Linhas

Rápido Crescimento

Outras 
APÊNDICE 7: Modelo de ficha de dados cadastrais do proprietário

OWunaf
de de 1.997.

\section{$\grave{A}$}

CESP - COMPANHIA ENERGÉTICA DE SÃO PAULO

SETOR DE ECOSSISTEMAS PARANAPANEMA

AVC BIOL JOÄO HENRIQUE PINHEIRO DIAS

VIVEIRO DE PRODUÇÃO DE MUDAS DE PRIMAVERA

AVENIDA DOS BARRAGEIROS, S/N ${ }^{\circ}$

CAIXA POSTAL 350

CEP 19274-000

PRIMAVERA, SP

TELEFAX: (018) 284-1175

\section{Assunto: Fomento Florestal}

no municipio de

Possuo uma propriedade rural denominada banhada pelo(a)

Tenho interesse em realizar o reflorestamento ciliar em uma área de aproximadamente desenvolvido por esta Empresa.

Agradeço desde já a atenção dispensada.

Atenciosamente,

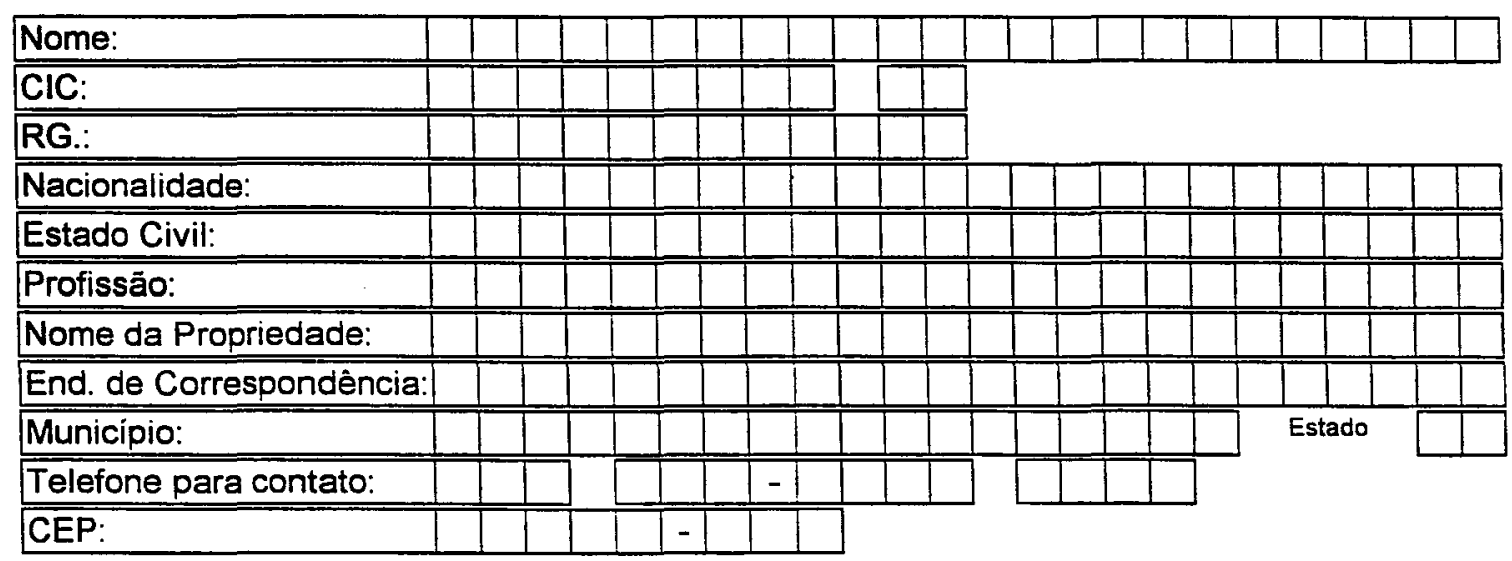

Obs: Percentual de Área Úmida:

Percentual de Área Seca:

Largura da faixa a ser reflorestada:

Comprimento da faixa a ser reflorestada:

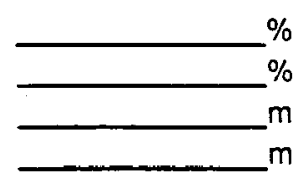


Objetivo: Relatar informações técnicas obtidas em visita a propriedade rural designada abaixo, verificando se a mesma atende aos requisitos mínimos para ingresso no Programa de Fomento Florestal.

Data da solicitação:

Data do primeiro contato:

\section{Data da visita a área:}

Propriedade rural:

Localização: Latitude:

Atividades desenvoividas: Longitude:

Área total da propriedade:

\section{Proprietário rural:}

Tipo de domínio:

Documento de identidade:

CPF:

Profissão:

Estado civil:

Nacionalidade:

Naturalidade:

Outras informações:

Endereço de domicilio do proprietário:

\section{Telefone/fax para contato:}

Pessoas autorizadas para contato:

Endereço/Localização da propriedade:

\section{Bacia hidrográfica da UHE:}

Tributário principal:

Afluente $\mathrm{ME}(\mathrm{)} \mathrm{MD}(\mathrm{)})$
Reservatório $\mathrm{ME}(\mathrm{)} \mathrm{MD}(\mathrm{)}$
Conferi e atesto como verdadeiras as informaçōes prestadas acima,




\section{Informações técnicas:}

\section{Conservação do solo}

Obras de conservação existentes:

Caracterização do solo:

Caracterização do relevo:

Cobertura atual:

Análise de solo: data:

$\mathrm{pH}:$

V\%:

2. Área de preservação permanente

Inundação:

Cobertura atual:

Caracterização da vegetação:

Porcentagem de área úmida:

Espécies observadas na região:

\section{Dimensão da área ciliar}

Largura:

Comprimento:

Área total:

\section{Quantidade de mudas necessárias:}

5. Proposta de início do plantio:

\section{Operações técnicas}

Construção de cercas

Roçada manual prévia

Máquinas e implementos

Alinhamento e marcação das covas

Coroamento para plantio

Coveamento manual

Adubação na cova

Transporte de mudas

Plantio florestal

Irrigações

Combate curativo à formigas

Roçada manual de manutenção

Capina manual em coroa

\section{Produtor}

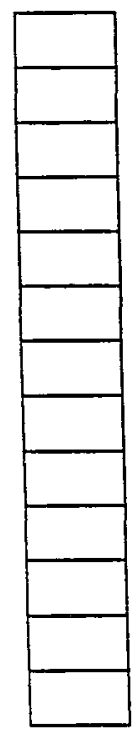

\section{CESP}

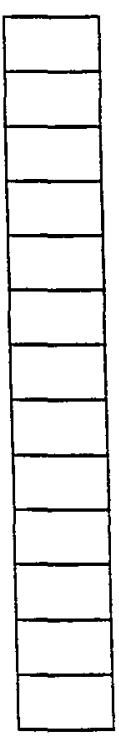


Croqui da Área de Plantio:

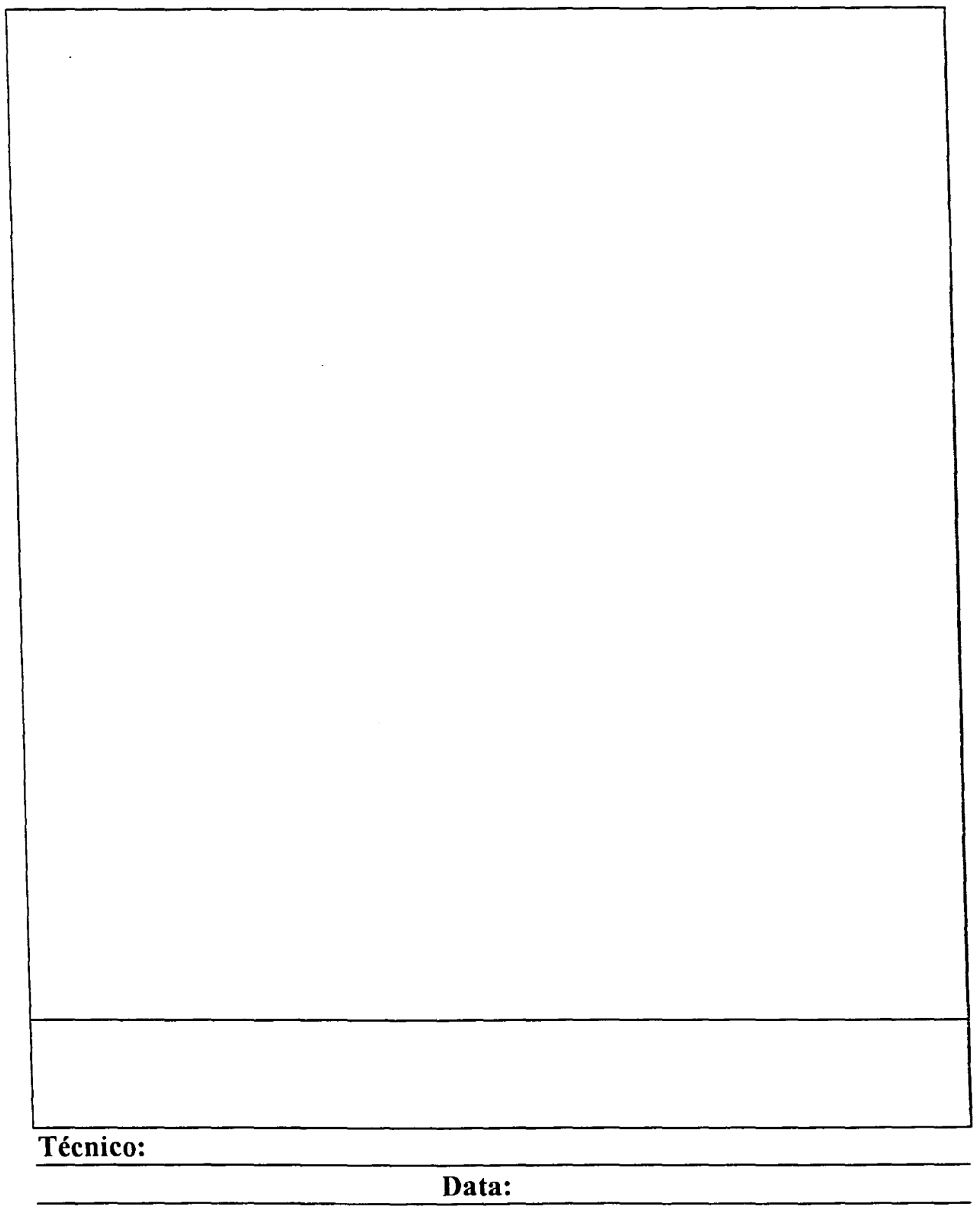

vistec.doc/cas 3 